UNIVERSIDADE DE SÃO PAULO

ESCOLA DE ENFERMAGEM DE RIBEIRÃO PRETO

ANNE MARIE WEISSHEIMER

Tradução, adaptação transcultural e validação para uso no Brasil do instrumento

Prenatal Psychosocial Profile 
ANNE MARIE WEISSHEIMER

\title{
Tradução, adaptação transcultural e validação para uso no Brasil do instrumento Prenatal Psychosocial Profile
}

\author{
Tese apresentada como requisito para \\ obtenção do título de Doutora em Enfermagem \\ em Saúde Pública pelo Programa de Pós- \\ Graduação do Departamento de Enfermagem \\ Materno-Infantil e Saúde Pública da Escola de \\ Enfermagem de Ribeirão Preto-USP. \\ Linha de pesquisa: Assistência à Saúde da \\ Mulher no Ciclo Vital \\ Orientadora: Profa. Dra. Marli Villela Mamede
}


AUTORIZO A REPRODUÇÃO E DIVULGAÇÃO TOTAL OU PARCIAL DESTE TRABALHO, POR QUALQUER MEIO CONVENCIONAL OU ELETRÔNICO, PARA FINS DE ESTUDO E PESQUISA, DESDE QUE CITADA A FONTE.

Weissheimer, Anne Marie

Tradução, adaptação transcultural e validação para uso no Brasil do instrumento Prenatal Psychosocial Profile. Ribeirão Preto, 2007. 133f.; $30 \mathrm{~cm}$.

Tese de Doutorado apresentada à Escola de Enfermagem de Ribeirão Preto/USP - Programa de Pósgraduação em Enfermagem em Saúde Pública.

Orientadora: Mamede, Marli Villela

1. Assistência pré-natal. 2. Estresse. 3. Apoio social.

4. Auto-estima. 5. Psicometria. 


\section{FOLHA DE APROVAÇÃO}

Anne Marie Weissheimer

Tradução, adaptação transcultural e validação para uso no Brasil do instrumento Prenatal Psychosocial Profile.

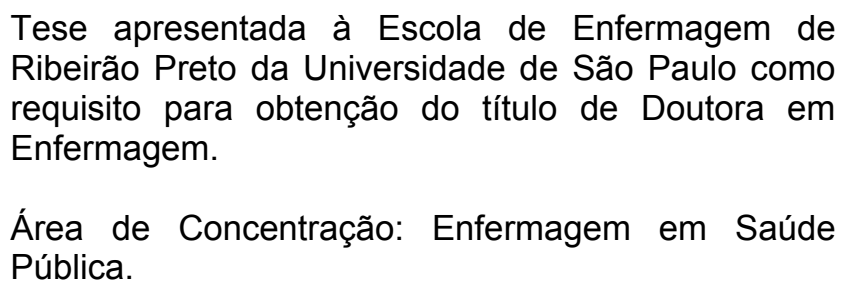

Aprovada em de 2007.

\section{BANCA EXAMINADORA}

Profa. Dra. Marli Villela Mamede

Instituição: EERP/USP

Assinatura:

Profa. Dra. Janine Schirmer

Instituição: ENF/EPM/UNIFESP Assinatura:

Profa. Dra. Ana Lúcia de Lourenzi Bonilha

Instituição: Esc. Enf./UFRGS Assinatura:

Profa. Dra. Rosana A. Spadoti Dantas

Instituição: EERP/USP Assinatura:

Profa. Dra. Marislei Sanches Panobianco

Instituição: EERP/USP

Assinatura: 
Aos meus pais,

Adalberto e Astrid, sólidos e constantes em oferecer amore exemplos. 


\section{AGRADECIMENTOS}

Aos meus pais que são fontes inesgotáveis de amor, segurança e incentivo.

Ao meu irmão Werner e minha cunhada Vera, por estarem sempre disponíveis e presentes. Parafraseando o Werner: "quis a vida que ele fosse meu irmão e meu amigo".

Ao Renato, tudo e todo, "no matter what".

À Nutti, por nutrir, cuidar e fazer parte de nossa família há mais de 38 anos, com amor e dedicação.

À Neli, por cuidar de mim e de minha casa com carinho e alegria.

À minha orientadora, professora doutora Marli Vilella Mamede, que com paciência e sabedoria infinitas me acompanhou, incentivou e guiou nesta jornada de crescimento profissional e pessoal. Agradeço, também, por sua amizade e acolhida.

Às professoras doutoras Janine Schirmer, Ana Lúcia de Lourenzi Bonilha, Rosana Aparecida Spadoti Dantas e Marislei Sanches Panobianco por colaborarem com a avaliação e com sugestões para este estudo. À professora doutora Rosana agradeço também a generosidade em compartilhar referências bibliográficas.

Às enfermeiras obstétricas, professoras doutoras Flávia Azevedo Gomes, Fabiana Villela Mamede, Ana Lúcia de Lourenzi Bonilha, Lilian Córdova Espírito Santo e Dora Lúcia Leidens Corrêa de Oliveira, que com gentileza e afinco disponibilizaram seu conhecimento e tempo para participarem dos comitês de especialistas no processo de tradução e adaptação transcultural do instrumento validado.

Às professoras doutoras Ida Haunss de Freitas Xavier e Maria Alice Dias da Silva Lima, à época, respectivamente, diretora e coordenadora de pós-graduação da Escola de Enfermagem da UFRGS, que me incentivaram a iniciar esta jornada e se desdobraram para que ela se realizasse.

À mestre Ceres Andréia de Oliveira, estatística de conhecimento ímpar, profissional incansável, alegre e com "Intel Inside".

Às minhas colegas e amigas da disciplina de Enfermagem no Cuidado à Mulher e à Chefia do Departamento de Enfermagem Materno-infantil da Escola de Enfermagem da UFRGS, que me apoiaram e permitiram o longo período de afastamento. 
Às amigas e colegas da EERP, moradoras do condomínio Aroeira, parceiras de chimarrão e longas conversas, todas vindas de outras cidades com o mesmo objetivo, Marilu, Luciana, Rosani, Aline, Eliza e Celmira, graças a vocês foi menos difícil! Além disso, agradeço aos amigos Miki, Leandro, Nelma, Juliana Bueno e Juliana Monteiro, sempre presentes e alegres.

À Eliane, que de mera colega de trabalho, passou a ser boa amiga e dividiu comigo alegrias e conquistas.

Às amigas e colegas Leila, Guida e Ana Maria, com quem dividi a orientadora, a sala das orientadoras, e também a afinidade pela paixão à enfermagem obstétrica e ao cuidado da mulher.

À psicóloga Janice Bacaltchuk Fischmann, que manteve minha sanidade através de doses equilibradas de profissionalismo, brilhantismo, empatia e bom humor.

Aos acadêmicos do curso de Enfermagem da UFRGS, coletadores incansáveis de dados, especialmente agradeço a Aline M. Schatkoski, Adele K. Pergher, Píter Z. Dal-Ri, Kelly Millioni e, com gás extra no final, Joice M. Schmalfuss.

Às tradutoras Elisa Schreiner e Thaís Pancich Olmedo, pela presteza, rapidez e eficiência.

Aos professores e funcionários da EERP/USP.

A todas as gestantes que tiveram a paciência e a disponibilidade de preencher o instrumento e que entenderam os motivos e a importância do estudo.

Finalmente, mas com a devida relevância, agradeço à CAPES, órgão de fomento do Programa de Qualificação Institucional, no qual estava inserida. 
In the morning when you rise,

Do you open up your eyes, see what I see?

Do you see the same things every day?

Do you think of a way to start the day

getting things in proportion?

Spread the news and help the world go round.

Have you heard of a time that will help us get it together again?

Have you heard of the word that will stop us

going wrong?

Well, the time is near, and the word you'll hear when you get things in perspective.

Spread the news and help the world go round.

There's a time and the time is now and it's right for me, it's right for me, and the time is now.

There's a word and the word is love and it's right for me, it's right for me, and the word is love.

Time and a word - YES 


\section{RESUMO}

WEISSHEIMER, Anne Marie. Tradução, adaptação transcultural e validação para uso no Brasil do instrumento Prenatal Psychosocial Profile. Tese (Doutorado) Escola de Enfermagem de Ribeirão Preto, Universidade de São Paulo, Ribeirão Preto, 2007.

A atenção qualificada à gestante no período pré-natal deve garantir a identificação precoce de fatores de risco gestacionais para além dos fatores biológicos. Deve-se valorizar o bem-estar psicossocial, pois este pode influenciar situações adversas à gestante. Em 1994, nos Estados Unidos, enfermeiras desenvolveram um instrumento denominado Prenatal Psychosocial Profile (PPP) para avaliar o bem-estar psicossocial de gestantes. Esta escala tem 44 itens divididos em quatro subescalas: estresse, apoio social recebido do companheiro, apoio social recebido de outras pessoas e auto-estima. $O$ presente estudo teve como objetivos realizar a adaptação transcultural do PPP para uso no Brasil e testar suas propriedades psicométricas em uma amostra de gestantes de Porto Alegre (RS). O processo de adaptação seguiu as seguintes etapas: tradução para português; síntese da primeira versão; avaliação por comitê de especialistas; back translation para idioma original (inglês); avaliação por comitê de especialistas para verificação de equivalência e validade de conteúdo; avaliação da back translation pela principal autora do instrumento; pré-teste da versão em português do PPP (PPP-VP); aplicação do PPP-VP em gestantes brasileiras. Participaram do estudo 241 gestantes que realizaram pré-natal na rede básica de saúde do município de Porto Alegre/RS. A idade das gestantes variou entre 18 e 42 anos (média=26,4; DP= 6,12 ); a idade gestacional variou entre 12 e 41 semanas (média=29; $D P=8,41$ ); 89 $(36,9 \%)$ eram primigestas; o número de consultas de pré-natal variou entre 1 e 18 (média=5; DP=2,82). Todas as subescalas do PPP-VP são compostas de 11 itens cada; as subescalas de estresse e de auto-estima têm escore mínimo de 11 e máximo de 44; ambas subescalas de apoio social têm escore mínimo de 11 e máximo de 66. Os escores médios e desvios-padrão obtidos foram de 18,84 $(D P=5,01)$ para a subescala de estresse; $53,49(D P=14,06)$ para o apoio do companheiro; 50,33 ( $\mathrm{DP}=14,85)$ para apoio de outras pessoas; e 32,54 (DP=5,07) para a auto-estima. Ao analisar a confiabilidade do PPP-VP, constatou-se que o mesmo apresenta características de estabilidade; a consistência interna foi verificada através do coeficiente de alfa de Cronbach, que teve valores de 0,71 para a subescala de estresse; 0,96 para o apoio do companheiro; 0,96 para o apoio de outras pessoas; e 0,79 para a auto-estima. A validade foi comprovada através da análise fatorial; a validade de construto confirmou a correlação negativa do estresse com o apoio social e a auto-estima, e a correlação positiva entre estes dois últimos. Diante dos resultados, propõe-se que o PPP-VP seja utilizado como ferramenta clínica, como meio para obter um escore de risco psicossocial que leve a intervenções de enfermagem para reduzir comportamentos de risco à saúde durante a gestação e suas conseqüências, como prematuridade e baixo peso, por exemplo.

Palavras-chave: assistência pré-natal; estresse; apoio social; auto-estima; psicometria. 


\begin{abstract}
WEISSHEIMER, Anne Marie. Translation, cross-cultural adaptation and validation for use in Brazil of the Prenatal Psychosocial Profile. Dissertation (Doctoral) - Nursing School of Ribeirão Preto, University of São Paulo, 2007.

Qualified attention to women during the prenatal period must guarantee early identification of gestational risk factors beyond biological factors. It is necessary to value psychosocial well-being since it might influence adverse situations to the pregnancy. In 1994, a group of North American nurses designed a tool called Prenatal Psychosocial Profile (PPP) to assess psychosocial well-being of pregnant women. This tool has 44 items divided in four subscales: stress, social support from partner, social support from other persons, and self-esteem. The purposes of this study were to perform the cross-cultural adaptation of the PPP for use in Brazil and to test its psychometric properties in a group of pregnant women of Porto Alegre/RS. The adaptation process followed these steps: translation to Portuguese; first version synthesis; expert committee evaluation; back translation to English; expert committee evaluation to verify equivalence and content validation; evaluation of the back translation by the main author of the tool; pretest of the PPP version in Portuguese (PPP-VP); validation of the PPP-VP with Brazilian pregnant women. The sample consisted of 241 pregnant women enrolled on prenatal care at the Basic Health Program of the city of Porto Alegre/RS/Brazil. The age of the women varied between 18 and 42 years (mean=26.4; $S D=6.12$ ); gestational age varied from 12 to 41 weeks (mean=29; $S D=8.41) ; 89(36.9 \%)$ were primigravida; the number of prenatal consultations varied from 1 to 18 (mean=5; $S D=2.82$ ). All the subscales from the PPP have 11 items each; stress and self-esteem subscales have a minimum score of 11 and a maximum of 44 ; both social support subscales have a minimum score of 11 and a maximum of 66 . The mean scores and standard deviations obtained were of $18.84(S D=5.01)$ for the stress subscale; $53.49(S D=14.06)$ for support from the partner; 50.33 ( $S D=14.85$ ) for social support from other persons; and 32.54 $(S D=5.07)$ for the self-esteem subscale. While verifying the reliability of the PPP, it was established that it has stability characteristics; the internal consistency was verified by the coefficient of Cronbach's alpha, with values of 0.71 for the stress subscale; 0.96 for support from the partner; 0.96 for support from other persons; and 0.79 for the self-esteem subscale. Validity was supported through factorial analysis; construct validity confirmed the negative correlations between stress with social support and self-esteem, and also by the positive correlation of the least. The results allow proposing that the PPP-VP should be used as a clinical tool, as means to obtain a psychosocial risk score which can lead to nursing interventions that will reduce health risk behaviors during pregnancy and its consequences, such as premature births and low birth weight.
\end{abstract}

Keywords: prenatal care; stress; social support; self-esteem; psychometrics. 


\section{RESUMEN}

WEISSHEIMER, Anne Marie. Traducción, adaptación transcultural y validación para el uso en Brasil del instrumento Prenatal Psychosocial Profile. Tesis (Doctorado) Escuela de Enfermería de Ribeirão Preto, Universidad de São Paulo, Ribeirão Preto, 2007.

La atención calificada a la gestante en el período prenatal debe garantizar la identificación precoz de factores de riesgos de la gestación más allá de los factores biologicos. Se debe valorizar el bienestar psicosocial, pues este puede alterar situaciones adversas a la gestante. En 1994, en los Estados Unidos, enfermeras desarrollaron un instrumento denominado Prenatal Psychosocial Profile (PPP) para evaluar el bienestar de las gestantes. Este instrumento consiste en 44 ítems divididos en 4 subescalas: estrés, apoyo social que se recibe del compañero, apoyo social que se recibe de otras personas, y autoestima. El presente estudio tuvo como objetivos realizar la adaptación transcultural del PPP para para el uso en Brasil e testar sus propriedades psicometricas en una muestra de gestantes de Porto Alegre/RS. El proceso de adaptación siguió las siguientes etapas: traducción para el portugués; síntesis de la primera versión; evaluación por un comité de especialistas; back translation para el idioma original (inglés); evaluación por un comité de especialistas para verificar la equivalencia y validez del contenido; evaluación de la back translation por la principal autora del instrumento; pretest de la versión en portugués del PPP (PPP-VP); aplicación del PPP-VP en gestantes brasileñas. Participaron del estudio 241 gestantes que realizaron prenatal en la red básica de salud de la ciudad de Porto Alegre/RS/Brasil. La edad de las gestantes varió entre 18 y 42 anos (promedio=26,4; $\mathrm{DP}=6,12$ ); el periodo de gestación varió entre 12 y 41 semanas (promedio=29; DP=8,41); $89(36,9 \%)$ estaban en su primer gestación; el número de consultas de prenatal varió entre 1 y 18 (promedio=5; $D P=2,82$ ). Todas las subescalas del PPP-VP están compuestas por 11 items cada; la subescala del estrés y la subescala de autoestima tienen una puntuación mínima de 11 y máxima de 44; las dos escalas de apoyo social tienen una puntuación mínima de 11 y máxima de 66. El promedio de la puntuación y los desvíos padrones obtenidos fueron de 18,84 ( $\mathrm{DP}=5,01)$ para la subescala del estrés; $53,49(\mathrm{DP}=14,06)$ para el apoyo del compañero; $50,33(\mathrm{DP}=14,85)$ para el apoyo de otras personas; y 32,54 $(\mathrm{DP}=5,07)$ para el autoestima. Al analizar la confiabilidad del PPP-VP, se pudo constatar que el mismo presenta características de estabilidad; la consistencia interna se verifico a través del coeficiente de alfa de Cronbach, que tuvo valores de 0,71 para la subescala del estrés; 0,96 para el apoyo del compañero; 0,96 para el apoyo de otras personas; y 0,79 para el autoestima. La validez fue comprobada a través del análisis factorial; la validez de construto confirmo la correlación negativa del estrés con el apoyo social y el autoestima, y la correlación positiva entre los dos últimos. Ante esos resultados, se propone que el PPP-VP sea utilizado como herramienta clínica, como medio de obtener una puntuación de riesgo psicossocial que lleve a las intervenciones de enfermería para reducir comportamientos de riesgo a la salud durante la gestación y sus consecuencias, como prematuridad y bajo peso.

Descriptores: atención prenatal; estrés; apoyo social; autoestima; psicometría. 


\section{LISTA DE TABELAS}

Tabela 1 - Estatística descritiva e consistência interna das medidas obtidas pelo PPP em sua versão adaptada para o português e versão original: fase pré-teste.

Tabela 2 - Distribuição das 241 gestantes do estudo conforme idade, escolaridade, idade gestacional, número de gestações, paridade, número de partos vaginais, de partos cesáreos, de abortos e número de consultas de pré-natal. Porto Alegre, 2007.

Tabela 3 -Valores de médias, desvios-padrão e amplitude de variação dos escores encontrados no PPP-VP e por Curry; Campbell; Christian (1994)....

Tabela 4 - Distribuição da freqüência das respostas das 241 gestantes aos itens da subescala de Estresse do PPP-VP. Porto Alegre, 2007.

Tabela 5 - Distribuição da freqüência das respostas das 241 gestantes aos itens da subescala de Apoio do Companheiro do PPP-VP. Porto Alegre, 2007.

Tabela 6 - Distribuição da freqüência das respostas das 241 gestantes aos itens da subescala de Apoio de Outras Pessoas do PPP-VP. Porto Alegre, 2007.

Tabela 7 - Distribuição da freqüência das respostas das 241 gestantes aos itens da subescala de Auto-estima do PPP-VP. Porto Alegre, 2007...

Tabela 8 - Médias, desvios-padrão e valores de $p$ do teste e reteste do PPPVP. Porto Alegre, 2007.

Tabela 9 - Valores de Alfa de Cronbach das subescalas do PPP-VP $(n=241)$. Porto Alegre, 2007

Tabela 10 - Valores dos coeficientes de alfa de Cronbach quando cada um dos itens da subescala de Estresse é excluído. Porto Alegre, 2007.

Tabela 11 - Valores dos coeficientes de alfa de Cronbach quando cada um dos itens da subescala de Apoio do Companheiro é excluído. Porto Alegre, 2007

Tabela 12 - Valores dos coeficientes de alfa de Cronbach quando cada um dos itens da subescala de Apoio de Outras Pessoas é excluído. Porto Alegre, 2007.

Tabela 13 - Valores dos coeficientes de alfa de Cronbach quando cada um dos itens da subescala de Auto-estima é excluído. Porto Alegre, 2007....

Tabela 14 - Médias, desvios-padrão e valores de $p$ do teste e pós-teste do PPP-VP. Porto Alegre, 2007

Tabela 15 - Avaliação das cargas fatoriais das subescalas do PPP-VP. Porto Alegre, 2007.

Tabela 16 - Análise da correlação de Pearson entre as subescalas do PPP-VP. Porto Alegre, 2007. 


\section{LISTA DE FIGURAS}

Figura 1 - Etapas do processo de tradução e adaptação do PPP seguidas

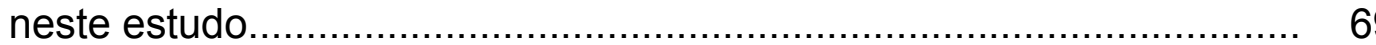




\section{LISTA DE QUADROS}

Quadro 1 - Estudos que utilizaram o Prenatal Psychosocial Profile (PPP)

Quadro 2 - Apresentação da avaliação qualitativa do PPP- VP, durante o préteste. Porto Alegre, 2007.

Quadro 3 - Comparação entre itens da subescala de Auto-estima com os itens da Escala de Auto-estima de Rosenberg, versão adaptada por Dini (2000). 


\section{SUMÁRIO}

1 INTRODUÇÃO

2 REVISÃO DA LITERATURA .................................................... 26

2.1 COMPORTAMENTOS DE RISCO NA GESTAÇÃO......................... 26

2.2 BEM-ESTAR PSICOSSOCIAL E GESTAÇÃO.................................. 34

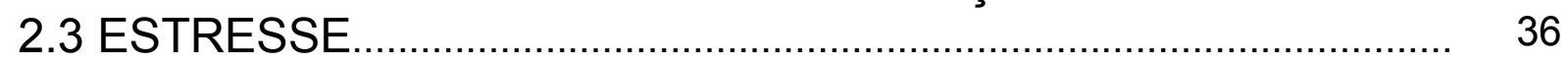

2.4 APOIO SOCIAL _................................................................................ 40

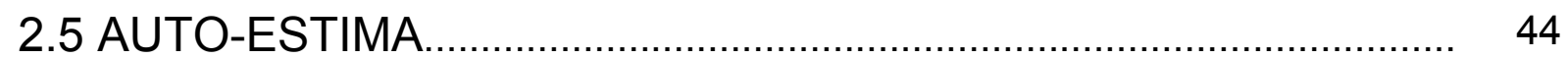

3 OBJETIVOS

3.1 OBJETIVO GERAL ................................................................... 49

3.2 OBJETIVOS ESPECÍFICOS....................................................... 49

4 REFERENCIAL TEÓRICO-METODOLÓGICO ……......................... 50

4.1 ADAPTAÇÃO TRANSCULTURAL DE INSTRUMENTOS DE

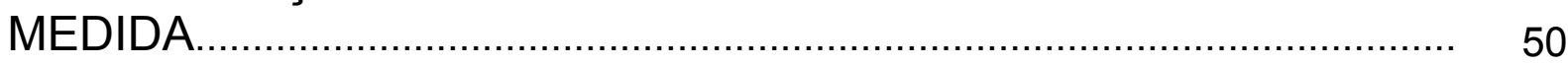

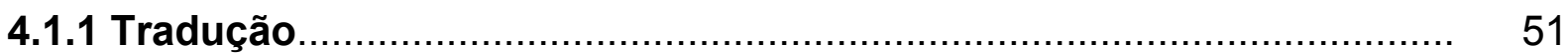

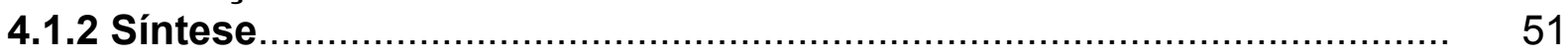

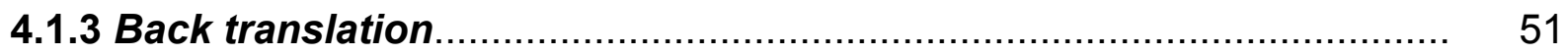

4.1.4 Comitê de especialistas..................................................................... 52

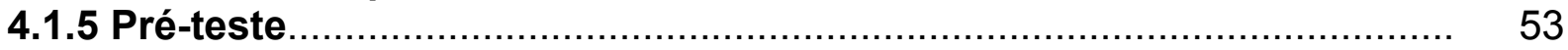

4.1.6 Verificação das propriedades psicométricas ........................................ 53

4.1.6.1 CONFIABILIDADE .................................................................. 53

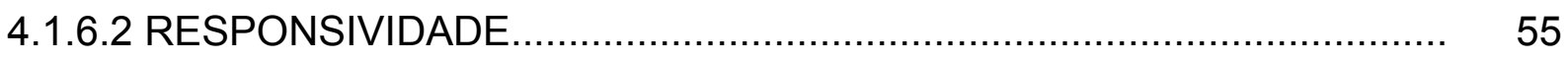

4.1.6.3 VALIDADE …………………………………………….... 55

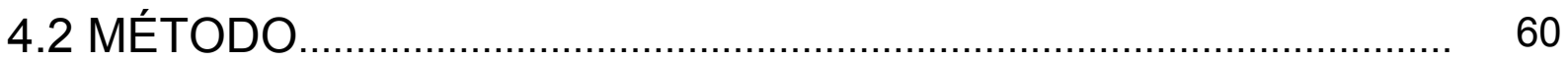

4.2.1 Etapas da adaptação transcultural do PPP....................................... 60

4.2.2 Procedimentos de coleta de dados.......................................................... 60

4.2.2.1 LOCAL DO ESTUDO......................................................................... 60

4.2.2.2 POPULAÇÃO-ALVO E AMOSTRA......................................................... 60

4.2.2.3 INSTRUMENTOS DE COLETA DE DADOS....................................... 61

4.3. PROCEDIMENTOS DE ANÁLISE..................................................... 64

4.4 PROCEDIMENTOS ÉTICOS ............................................................... 65

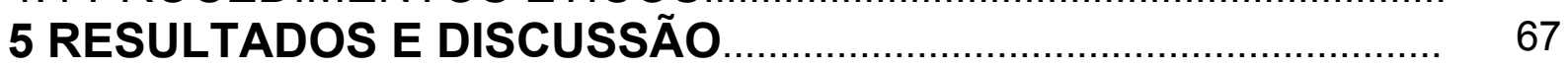

5.1 TRADUÇÃO PARA A LÍNGUA PORTUGUESA E ADAPTAÇÃO TRANSCULTURAL DO PPP.............................................................. 67

5.1.1 Tradução e adaptação transcultural do PPP.......................................... 67

5.1.2 Pré-teste do PPP, versão em português................................................ $\quad 70$

5.2 CARACTERIZAÇÃO DA AMOSTRA ESTUDADA ........................... 73

5.3 ESTATÍSTICA DESCRITIVA DO PPP-VP................................... 75

5.3.1 Distribuição da frequêencia de respostas para cada item de cada subescala do PPP-VP........................................................................ 76

5.4 AVALIAÇÃO DAS PROPRIEDADES PSICOMÉTRICAS DO
PPP-VP.

5.4.1 Confiabilidade .................................................................................. 84

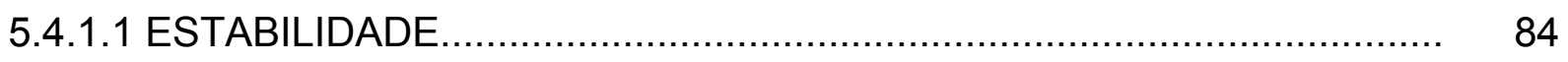




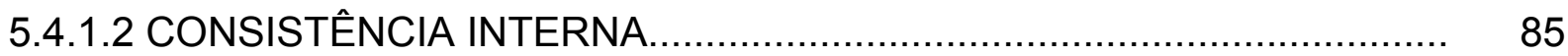

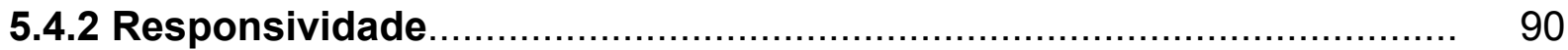

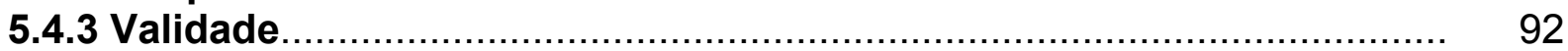

5.4.3.1 VALIDADE DE CONSTRUTO_......................................................... 94

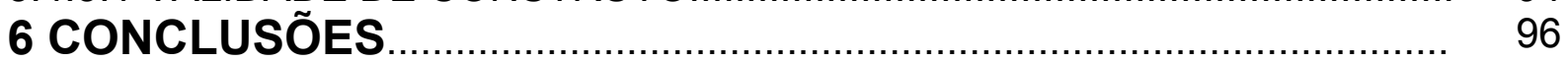

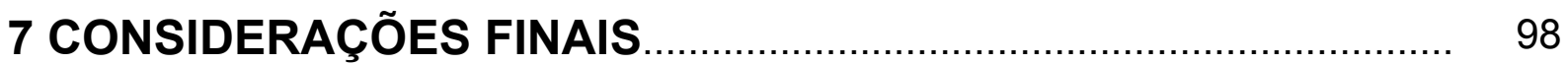

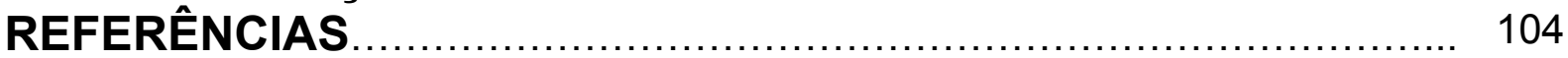

APÊNDICES

APÊNDICE A - Manual de Orientações Para Coleta de Dados......................... 111

APÊNDICE B - Dados de Identificação, Clínicos e Obstétricos......................... 113

APÊNDICE C - Glossário Codificação Pesquisa.................................................... 114

APÊNDICE D - Termo de Consentimento Livre e Esclarecido........................... 118

APÊNDICE E - Carta ao Comitê de Ética em Pesquisa com Fluxo de

Encaminhamento para Profissionais da Área de Saúde Mental......................... 119

APÊNDICE F - Versão final em português do Prenatal Psychosocial Profile

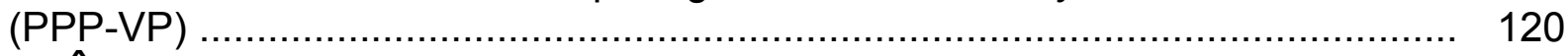

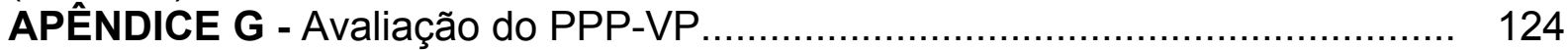

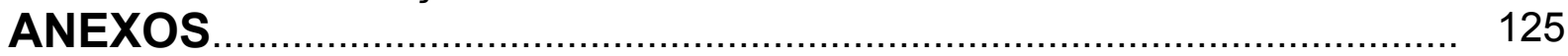

ANEXO A - The Prenatal Psychosocial Profile (PPP) ............................ 126

ANEXO B - E-mails Autorização Professora Mary Ann Curry ........................... 128

ANEXO C - Aprovação Comitê de Ética em Pesquisa da Secretaria Municipal de Saúde de Porto Alegre...................................................................... 130

ANEXO D - Back-translation (consenso tradutores)....................................... 131

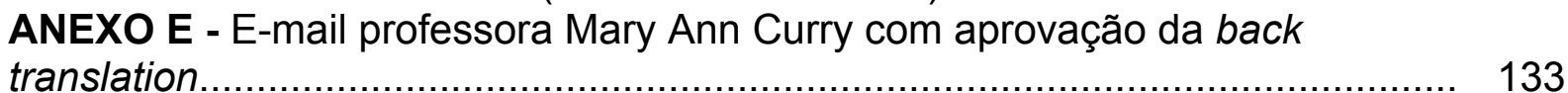




\section{INTRODUÇÃO}

A gestação é o período fisiológico que culmina com o nascimento de um novo ser humano. O parto e o nascimento fazem parte da humanidade e como tais possuem diferentes significados: social, religioso, existencial, cultural, demográfico e também pessoal (WEISSHEIMER, 2002). Para Helman (2000), em todas as sociedades humanas, a gestação e o parto são mais do que eventos biológicos; são também partes de uma transição importante da mulher no seu status social, durante o qual deve ser protegida por meio da observação de alguns ritos de crenças e comportamentos. O papel feminino, durante estes eventos, é alterado na sociedade e na família, e suas repercussões ocorrem em amplitudes variadas, atingindo relações intrafamiliares, profissionais, sociais e da mulher com seu filho.

O conhecimento adquirido na área da obstetrícia nos faz conhecer vários fatores que podem ser considerados como potenciais geradores de situações de risco para a gestação. Estes fatores são classificados como riscos sociodemográficos, ambientais, clínicos e obstétricos (BRASIL, 2006; SINCLAIR, 2002). Alguns são impossíveis de serem preditos ou evitados, porém um grande número deles pode ser antecipado, erradicado ou tratado. Desta forma, a atenção qualificada dispensada à mulher na gestação, durante o pré-natal, deveria garantir a identificação precoce dos fatores de risco gestacionais, para além dos fatores biofísicos. Preconiza-se que a atenção ao pré-natal de qualidade compreenda a atenção integral à mulher e à família, pois a gestação é um período paradoxalmente fisiológico e crítico, que pode ser permeado por situações de estresse e dificuldades psicossociais que influenciam nos seus resultados, conforme o apoio recebido pelo

\footnotetext{
* Nesta tese foram observadas as orientações para apresentação e elaboração de referências (conforme a ABNT) de: FUNARO, Vânia M. B. de O. (coord.) et al. Diretrizes para apresentação de dissertações e teses da USP: documento eletrônico e impresso. São Paulo: SIBi-USP, 2004.
} 
parceiro e outras pessoas, o nível de estresse e a auto-estima (AARONSON, 1989; BROWN, 1986b, ISTVAN, 1986; JESSE; ALLIGOOD, 2002; JESSE; REED, 2004; NORBECK; ANDERSON, 1989; OAKLEY; RAJAN; GRANT, 1990).

Nesse sentido, o bem-estar psicossocial deve ser valorizado, pois pode proteger a mulher grávida de situações adversas, ou mesmo alterá-las, por meio da mudança de comportamentos de risco à gestação, como a diminuição do uso de substâncias químicas (o álcool e o tabaco) e a nutrição adequada. Por conseqüência destas mudanças, ou intervenções de profissionais de saúde, poderemos ter recémnascidos com maior peso e a termo, saudáveis e sem repercussões negativas física, emocional e financeiramente para as famílias e a sociedade.

Apesar das evidências destes fatos, as avaliações de risco no pré-natal, em geral, examinam muito mais os efeitos de fatores biofísicos, enquanto a influência social e psicológica e os estilos de vida são deixados de lado (JESSE; ALLIGOOD, 2002).

Acreditamos que os sentimentos de uma mulher em relação à sua gestação, sua auto-estima, o apoio social que recebe e o estresse sofrido durante a gestação podem afetar o desfecho dessa gravidez, motivo pelo qual esse conhecimento tornou-se o objeto de interesse e estudo desta pesquisadora.

O apoio psicossocial é um dos fatores que permite que as mulheres alcancem o bem-estar psicossocial, além da manutenção de níveis de estresse adequados e de auto-estima elevada. É através das teias das relações sociais, sejam elas familiares ou construídas por outros vínculos, que as gestantes obterão estabilidade para enfrentarem o período gestacional, naturalmente permeado de altos e baixos conforme oscilações hormonais. A vivência de uma crise econômica pode estar presente em todas as camadas sociais e a vinda de um filho, ou mais um filho, pode 
gerar insegurança financeira no seio familiar. O desejo de prover, proteger e bem educar parece ser inerente à maioria das mães.

Algumas situações de pobreza, abandono social e familiar, difícil acesso à educação e a cuidados básicos de saúde e pouco ou inadequado conhecimento sobre os riscos à gestação fazem com que algumas mulheres assumam comportamentos nocivos a ela e ao concepto. Helman (2000) reforça isso, afirmando que muitas culturas acreditam que o comportamento materno durante a gestação, como aqueles relacionados à dieta, às atividades físicas, à conduta moral, ao estado de espírito e ao uso de substâncias, pode afetar diretamente a fisiologia da reprodução e causar danos ao feto. Entretanto, o autor refere-se a alguns hábitos e costumes tidos como normais nestes grupos, e lembra que nem todos os tabus e restrições acerca das mulheres grávidas protegem a mãe ou o feto de danos físicos, e que a mulher grávida está, também, em uma situação de vulnerabilidade social e de ambigüidade de papéis.

Raines e Morgan (2000, p. 168) reforçam a necessidade de a enfermagem "conhecer e respeitar os valores, crenças e práticas culturalmente arraigadas em sua clientela para garantir cuidado seguro e de qualidade, além do uso apropriado do sistema de cuidado de saúde", já que diferentes grupos culturais têm suas crenças sobre os significados de saúde, a manutenção da saúde e sobre os comportamentos corretos para a prevenção de doenças.

Assim, em relação à vulnerabilidade a que os indivíduos se submetem, em nossa prática como enfermeira obstétrica na assistência a gestantes durante o prénatal, nos deparamos com gestantes que se expõem a vários fatores de risco, sejam eles extrínsecos e intrínsecos, mesmo conhecedoras dos perigos a que elas e seus filhos estão sujeitos. Ao mesmo tempo, percebemos que a conduta das gestantes 
em relação à prevenção de riscos à gestação e ao bebê parece estar relacionada à sua inserção em determinados grupos culturais, que levam os seus integrantes à busca de um bem-estar psicossocial e entrosamento social.

Trazemos, portanto, como pressuposto que as gestantes que alcançam algum bem-estar psicossocial apresentam comportamentos mais saudáveis à gestação.

Acreditamos ser o período pré-natal fundamental para que se obtenha um bom desfecho da gestação, integrando atividades de educação e promoção da saúde. Conforme Meurer e Taren (1996), os programas de educação para a saúde, com orientações sobre nutrição, exercícios, redução de estresse, atividades relacionadas ao trabalho, uso adequado de medicações e maneiras de reduzir ou eliminar hábitos nocivos, como o tabaco, o álcool e drogas, devem ser incorporados às consultas voltadas à avaliação clínica. "Fornecer às mulheres e a seus parceiros conhecimentos a respeito de comportamentos saudáveis e sobre as alterações físicas e emocionais que ocorrem na gestação dá a eles sentimentos de bem-estar e auto-estima" (MEURER; TAREN, 1996, p. 42).

Jesse e Alligood (2002) basearam-se nos conceitos de Jean Watson para desenvolverem a teoria HOPE (Holistic Obstetrical Problem Evaluation), na qual sustentam que a única maneira de conhecer a gestante no todo é através da avaliação do nível de harmonia/desarmonia na gravidez. Para Watson (JESSE; ALLIGOOD, 2002) corpo-mente-espírito são a unidade através da qual as práticas de cuidado integram conhecimentos biofísicos, psicossociais e espirituais para obtenção de resultados positivos de saúde. Jesse e Alligood (2002) citam que Watson propõe em sua teoria de enfermagem que são as percepções individuais sobre a saúde, ou seja, a maneira como cada pessoa pensa sobre sua própria saúde, que levam às melhores condições de saúde. Por harmonia/desarmonia na 
gravidez, Jesse e Alligood (2002, p. 588) compreendem "um menor ou maior índice de risco à gestação".

A utilização de instrumentos que possam facilitar a identificação das condições psicossociais das gestantes, que possam trazer à luz outros aspectos das suas vidas cotidianas, que possam favorecer a ampliação da visão atual da gravidez para além de seus aspectos biológicos, deve ser considerada como importante estratégia para o alcance de uma gravidez com menor risco.

No Brasil, existem poucos estudos que avaliam o perfil psicossocial de gestantes em relação aos comportamentos considerados de risco à gestação, de forma a contribuir para a melhoria da qualidade de vida das mulheres e seus filhos. Da mesma forma, não se conhecem no país instrumentos específicos para este fim, quer seja construído ou adaptado para a nossa língua ou cultura. Assim, faz-se necessária a tradução, adaptação cultural e validação de instrumentos confiáveis já disponíveis em outro idioma.

O instrumento encontrado na literatura internacional que nos pareceu ser pertinente para este desiderato foi o Prenatal Psychosocial Profile (Perfil Psicossocial no Pré-natal - PPP), criado especificamente para o uso com gestantes e que oferece elementos para se identificarem dimensões do perfil psicossocial das mesmas.

O instrumento denominado Prenatal Psychosocial Profile (PPP) (ANEXO A), ou Perfil Psicossocial no Pré-natal, foi desenvolvido por Curry, Campbell e Christian (1994) com a finalidade de medir as percepções da mulher sobre o estresse, apoio do companheiro, apoio de outros e auto-estima durante a gestação. Para as autoras, o instrumento destina-se, principalmente, para as gestantes com desvantagens 
socioeconômicas já que é nesses grupos que há maior incidência de gestações com desfechos insatisfatórios (prematuridade e baixo peso ao nascimento).

O marco conceitual de Curry, Campbell e Christian (1994) baseia-se na revisão da literatura que Ihes permitiu relacionar respostas comportamentais ao estresse, apoio social, auto-estima e resultados da gestação. Somando-se às evidências de que cada um desses fatores pode estar independentemente relacionado aos resultados da gestação, a inter-relação desses fatores e seu efeito conjunto nesses resultados parece ser um importante foco de estudo.

O PPP é uma escala do tipo Likert, com 44 itens, baseada em instrumentos previamente existentes que medem o estresse, o apoio social e a auto-estima e que foram escolhidos após serem avaliados por suas propriedades psicométricas, utilidade clínica e conceptualização.

A escala que avalia o estresse foi formulada pelas autoras após rejeitarem outros instrumentos que consideraram insatisfatórios por sua extensão, por falharem em mensurar a percepção de estressores vigentes, ou falharem em mensurar a extensão ou impacto dos estressores. De um conjunto inicial de 18 itens selecionados da Escala Daily Hassles"; o instrumento foi reduzido para 11 itens após contato com os autores da escala inicial, que ofereceram informações sobre sua sensibilidade com populações femininas, e a avaliação de dez profissionais que atendiam em clínicas de pré-natal quanto à adequação, clareza e abrangência. Foi realizado um pré-teste com a escala obtida, com resultados satisfatórios.

A escala que mensura o apoio social, através de 11 itens que avaliam o apoio do parceiro e que se repetem para avaliar o apoio recebido de outras pessoas significativas, foi selecionada da versão reduzida do Brown's Support Behavior

\footnotetext{
\# KANNER, A.; COYNE, J.; SCHAEFER, C.; LAZARUS, R. Comparision of two modes of stress measurement : daily hassles and uplifts versus major life events. Journal of Behavioral Medicine. s.l., v. 4, p 1-39, 1981.
} 
Inventory $(\mathrm{SBI})$ - Inventário de Comportamentos de Apoio de Brown ${ }^{*}$ O SBI é um instrumento unidimensional que mede o nível de abrangência do apoio percebido durante a gestação. Para Brown (1986a), criadora do SBI, as fontes de apoio (companheiro e outras pessoas) são independentes uma da outra e também se inter-relacionam. Curry, Campbell e Christian (1994) escolheram o SBI por sua brevidade e também por ser importante, conceptualmente, escolher um instrumento que verificasse essas duas fontes de apoio, principalmente ao estudarmos gestantes de baixa renda que não têm companheiro. As propriedades psicométricas do SBI foram consideradas satisfatórias.

A escala de auto-estima Rosenberg* mensura tanto a auto-estima como a auto-aceitação. Foi selecionada por Curry, Campbell e Christian (1994) por sua brevidade e por ter sido amplamente usada com gestantes**. Foi adicionado um item extra (Você acha que controla a sua vida) conforme experiência clínica das autoras que acreditam que o controle possa ser um fator-chave intrapsíquico da auto-estima, já que pessoas que têm um controle sobre as suas vidas tendem a ter maior autoestima. As propriedades psicométricas da escala de auto-estima de Rosenberg com gestantes eram satisfatórias ${ }^{\#}$, e o item sobre o controle foi avaliado por 10 profissionais que atuam com gestantes que o consideraram um indicador válido de auto-estima conforme observado na prática.

Inicialmente, Curry, Campbell e Christian (1994) fizeram um estudo com 91 gestantes, com os objetivos de testar a validade da escala de estresse, examinar as

\footnotetext{
${ }^{¥}$ BROWN, Mary Annette. Social support during pregnancy: a unidimensional or multidimensional construct? Nursing Research, Hagerstown, MD, USA, v. 35, n. 1, p. 4-9, jan.-feb., 1986.

${ }^{*}$ ROSENBERG, Morris. Society and the adolescent self image. Princeton, NJ: Princeton University Press, 1965.

${ }^{* *}$ ROBINSON, J.; SHAVER, P. Measures of social psychological attitudes (rev. ed.). Ann Arbor: Survey Research Center Institute for Social Research, 1973.

\# MERCER, R.; FERKETICH, S. Stress and social support as predictors of anxiety and depression during pregnancy. Advances in Nursing Science, s.l., v. 10, n. 2, p. 26-39, 1988.
} 
inter-relações entre os fatores e determinar a confiabilidade das subescalas. Os coeficientes alfa de Cronbach foram de 0,78 para a escala de estresse; 0,93 para o apoio social do companheiro; 0,95 para o apoio social de outras pessoas e de 0,89 para a auto-estima. As correlações entre as subescalas reforçaram a relação entre os fatores propostos no marco conceitual (CURRY; CAMPBELL; CHRISTIAN, 1994). Posteriormente, foi realizado um segundo estudo, com 88 gestantes, para testar a validade convergente da escala de estresse e examinar a confiabilidade do teste/reteste em todas as quatro subescalas. A validade convergente da medida de estresse foi testada usando Barnard's Difficult Life Circumstances Scale*, havendo correlação significativa $(r=0,71)$ entre as duas e indicando validade convergente. As correlações entre os escores de teste/reteste mostraram estabilidade moderada ao longo do tempo, porém tal resultado pode ter sido prejudicado pela variação ampla do tempo entre as duas aplicações do instrumento (seis a 56 dias). Os coeficientes de alfa de Cronbach foram satisfatoriamente altos em ambas as coletas (CURRY; CAMPBELL; CHRISTIAN, 1994).

Os resultados obtidos pelas autoras do PPP e por outros pesquisadores estão expostos no Quadro 1, e demonstram ser o instrumento PPP confiável e efetivo para o uso com gestantes, o que justifica a proposta de adaptação do mesmo para a cultura brasileira.

Para facilitar o acompanhamento do desenvolvimento da presente pesquisa, inicialmente apresentamos os conceitos básicos de cuidado pré-natal, os comportamentos que podem ser definidos como de risco à gestação, diferenciandoos de gestação de risco. Após, são ilustrados os construtos utilizados pelas autoras para elaborar o Prenatal Psychosocial Profile (PPP), que são o estresse, o apoio

\footnotetext{
*BARNARD, K. Difficult Life Circumstances Scale. Unpublished raw data, 1988.
} 
social e a auto-estima e suas relações com a gestação. Em seguida é apresentado o referencial teórico-metodológico no qual estão descritos os procedimentos metodológicos para proceder à tradução, adaptação e validação para utilização em língua portuguesa no Brasil. Os resultados são apresentados e discutidos e finalmente as conclusões e sugestões para a incorporação do Prenatal Psychosocial Profile $(P P P)$ no dia-a-dia do atendimento pré-natal encerram o relatório desta tese.

\begin{tabular}{|c|c|c|c|c|}
\hline $\begin{array}{l}\text { Título e tamanho da } \\
\text { amostra (n) }\end{array}$ & Autores & Ano & $\begin{array}{c}\text { Periódicol } \\
\text { País de publicação }\end{array}$ & $\begin{array}{l}\text { Confiabilidade } \\
\text { conforme alfa } \\
\text { de Cronbach }\end{array}$ \\
\hline $\begin{array}{l}\text { The prenatal } \\
\text { psychosocial profile: a } \\
\text { research and clinical } \\
\text { tool. } \\
(n=3.444)\end{array}$ & $\begin{array}{l}\text { CURRY, Mary Ann; } \\
\text { BURTON, Deborah, } \\
\text { FIELDS, Jonathan. }\end{array}$ & 1998 & $\begin{array}{l}\text { Research in Nursing } \\
\text { \& Health, } \\
\text { Estados Unidos. }\end{array}$ & $\begin{array}{l}\text { Estresse } 0,73 \\
\text { Apoio Social } \\
0,94 \\
\text { Auto-estima } \\
0,84\end{array}$ \\
\hline $\begin{array}{l}\text { The interrelationships } \\
\text { between abuse, } \\
\text { substance use, and } \\
\text { psychosocial stress } \\
\text { during pregnancy. } \\
(\mathrm{n}=1.937)\end{array}$ & CURRY, Mary Ann & 1998 & $\begin{array}{l}\text { Journal of Obstetric, } \\
\text { Gynecologic and } \\
\text { Neonatal Nursing, } \\
\text { Estados Unidos }\end{array}$ & $\begin{array}{l}\text { Estresse } 0,73 \\
\text { Apoio Social } \\
0,94 \\
\text { Auto-estima } \\
0,84\end{array}$ \\
\hline $\begin{array}{l}\text { Holistic obstetrical } \\
\text { problem evaluation } \\
\text { (HOPE): testing a theory } \\
\text { to predict birth outcomes } \\
\text { in a group of women } \\
\text { from Appalachia } \\
(n=120)\end{array}$ & $\begin{array}{l}\text { JESSE, D. Elizabeth; } \\
\text { ALLIGOOD, Martha } \\
\text { R. }\end{array}$ & 2002 & $\begin{array}{l}\text { Health Care for } \\
\text { Women International, } \\
\text { Estados Unidos }\end{array}$ & $\begin{array}{l}\text { Estresse } 0,67 \\
\text { Apoio Social } \\
0,96 \\
\text { Auto-estima } \\
0,82\end{array}$ \\
\hline $\begin{array}{l}\text { Maternal psychosocial } \\
\text { risks predict preterm } \\
\text { birth in a group of } \\
\text { women from Appalachia } \\
(n=120)\end{array}$ & $\begin{array}{l}\text { JESSE D. Elizabeth; } \\
\text { SEAVER, William; } \\
\text { WALLACE, Debra C. }\end{array}$ & 2003 & $\begin{array}{l}\text { Midwifery, } \\
\text { Estados Unidos }\end{array}$ & $\begin{array}{l}\text { Estresse 0,67 } \\
\text { Apoio Social } \\
0,96 \\
\text { Auto-estima } \\
0,82 \\
\end{array}$ \\
\hline $\begin{array}{l}\text { Effects of spirituality and } \\
\text { psychosocial well-being } \\
\text { on health risk behaviors } \\
\text { in Appalachian pregnant } \\
\text { women. } \\
(n=120)\end{array}$ & $\begin{array}{l}\text { JESSE, D. Elizabeth; } \\
\text { REED, Pamela G. }\end{array}$ & 2004 & $\begin{array}{l}\text { Journal of Obstetric, } \\
\text { Gynecologic and } \\
\text { Neonatal Nursing, } \\
\text { Estados Unidos }\end{array}$ & $\begin{array}{l}\text { Estresse } 0,67 \\
\text { Apoio Social } \\
0,96 \\
\text { Auto-estima } \\
0,82\end{array}$ \\
\hline $\begin{array}{l}\text { Expanding } \\
\text { developmental and } \\
\text { behavioral services for } \\
\text { newborns in primary } \\
\text { care: effects on parental } \\
\text { well-being, practice and } \\
\text { satisfaction* } \\
(\mathrm{n}=439)\end{array}$ & $\begin{array}{l}\text { JOHNSTON, Brian } \\
\text { D.; HUEBNER, } \\
\text { Colleen E.; TYLL, } \\
\text { Lynda T; BARLOW, } \\
\text { William E.; } \\
\text { THOMPSON, Robert } \\
\text { S. }\end{array}$ & 2004 & $\begin{array}{l}\text { American Journal of } \\
\text { Preventive Medicine, } \\
\text { Estados Unidos }\end{array}$ & Estresse 0,67 \\
\hline
\end{tabular}


(CONTINUAÇÃO)

\begin{tabular}{|c|c|c|c|c|}
\hline $\begin{array}{l}\text { Título e tamanho da } \\
\text { amostra (n) }\end{array}$ & Autores & Ano & $\begin{array}{c}\text { Periódicol } \\
\text { País de publicação }\end{array}$ & $\begin{array}{c}\text { Confiabilidade } \\
\text { conforme alfa } \\
\text { de Cronbach }\end{array}$ \\
\hline $\begin{array}{l}\text { Risk factors for } \\
\text { spontaneous preterm } \\
\text { birth among Aboriginal } \\
\text { and non-Aboriginal } \\
\text { women in Manitoba** } \\
(n=226)\end{array}$ & $\begin{array}{l}\text { HEAMAN, Maureen } \\
\text { I.; BLANCHARD, } \\
\text { James F.; GUPTON, } \\
\text { Annette L.; } \\
\text { MOFFATT, Michael } \\
\text { E. K.; et al. }\end{array}$ & 2005 & $\begin{array}{l}\text { Paediatric and } \\
\text { Perinatal } \\
\text { Epidemiology, } \\
\text { Estados Unidos }\end{array}$ & $\begin{array}{l}\text { Estresse } 0,73 \\
\text { Apoio Social } \\
0,94 \\
\text { Auto-estima } \\
0,84\end{array}$ \\
\hline $\begin{array}{l}\text { Risks and protective } \\
\text { factors associated with } \\
\text { symptoms of depression } \\
\text { in low-income African } \\
\text { American and } \\
\text { Caucasian women } \\
\text { during pregnancy. } \\
(n=130)\end{array}$ & $\begin{array}{l}\text { JESSE, D. Elizabeth; } \\
\text { WALCOTT- } \\
\text { McQUIGG, } \\
\text { Jacqueline; } \\
\text { MARIELLA, Anne; } \\
\text { SWANSON, Melvin } \\
\text { S. }\end{array}$ & 2005 & $\begin{array}{l}\text { Journal of Midwifery } \\
\text { and Women's Health, } \\
\text { Estados Unidos }\end{array}$ & $\begin{array}{l}\text { Estresse } 0,74 \\
\text { Apoio Social } \\
0,78 \\
\text { Auto-estima } \\
0,79\end{array}$ \\
\hline $\begin{array}{l}\text { Preconceptional health: } \\
\text { risks of adverse } \\
\text { pregnancy outcomes by } \\
\text { reproductive life stage in } \\
\text { the Central Pennsylvania } \\
\text { Women's Health Study } \\
(\text { CePAWHS)* } \\
(\mathrm{n}=2.002)\end{array}$ & $\begin{array}{l}\text { WEISMAN, Carol S; } \\
\text { HILLEMEIER, } \\
\text { Marianne M; CHASE, } \\
\text { Gary A.; DYER, } \\
\text { Anne-Marie; et al. }\end{array}$ & 2006 & $\begin{array}{l}\text { Women's Health } \\
\text { Issues, } \\
\text { Estados Unidos }\end{array}$ & Estresse 0,69 \\
\hline $\begin{array}{l}\text { Nurse case } \\
\text { management for } \\
\text { pregnant women } \\
\text { experiencing or at risk } \\
\text { for abuse } \\
(n=1.000)\end{array}$ & $\begin{array}{l}\text { CURRY, Mary Ann; } \\
\text { DURHAM, Laurel; } \\
\text { BULLOCK, Linda; } \\
\text { BLOOM, Tina; } \\
\text { DAVIS, Jan. }\end{array}$ & 2006 & $\begin{array}{l}\text { Journal of Obstetric, } \\
\text { Gynecologic and } \\
\text { Neonatal Nursing, } \\
\text { Estados Unidos }\end{array}$ & $\begin{array}{l}\text { Estresse } 0,73 \\
\text { Apoio Social } \\
0,94 \\
\text { Auto-estima } \\
0,84\end{array}$ \\
\hline
\end{tabular}

* Somente utilizou a subescala de avaliação do estresse.

** Adaptou o PPP para administração no puerpério.

Quadro 1 - Estudos que utilizaram o Prenatal Psychosocial Profile (PPP). 


\section{REVISÃO DA LITERATURA}

\subsection{COMPORTAMENTOS DE RISCO NA GESTAÇÃO}

Com o passar dos anos, e a subseqüente evolução do conhecimento científico e dos aparatos tecnológicos, a detecção precoce e o tratamento de distúrbios da gestação levaram a uma queda da mortalidade materna. Entretanto, a morbidade materna e a perinatal permanecem exercendo grande efeito econômico e social por estarem associadas à ocorrência de estados de morbidade materna, muitas vezes graves, de recém-nascidos com problemas físicos ou mentais, ou de extrema prematuridade, entre outras muitas condições.

A maioria das mulheres procura atendimento pré-natal em um período posterior àquele no qual o feto pode ter seu desenvolvimento mais afetado por efeitos adversos (AUMANN; BAIRD, 1996), sendo importante lembrar que a maioria dos fatores que interferem no desenvolvimento da gestação já está presente antes da concepção. Aumann e Baird (1996) reforçam a necessidade de avaliar a existência de riscos e procurar intervenções adequadas e em tempo oportuno para se conseguir a prevenção de condições incapacitantes.

Ao discorrerem sobre a avaliação do risco em gestantes, Aumann e Baird (1996) categorizam os fatores de risco como socioeconômicos, demográficos, e médicos, e, dentro dessa última categoria, avalia-se a história obstétrica pregressa e a atual, a situação clínica materna e os hábitos.

Aumann e Baird (1996, p. 33) afirmam, ainda, que:

ao ser concebido, o feto recebe seu próprio potencial genético. Esse potencial genético de inteligência, desenvolvimento e qualidade de vida encontra, durante a gestação, muitos obstáculos ambientais, físicos, sociais e psicológicos. A capacidade do feto de vencer esses 
obstáculos irá depender, em grande parte, do atendimento de saúde oferecido à gestante.

É importante, entretanto, caracterizar a gestação chamada de alto risco, assim diferenciando daquela que possui fatores de risco, estes inerentes a todas as gestações.

Schirmer, Sumita e Fustinoni (2002, p. 186) afirmam que "a gestação não é doença, mas um fenômeno fisiológico que acontece no corpo da mulher inserida em um contexto sociocultural, pautado pela desigualdade de gênero que determina menos poder de decisão às mulheres". As autoras reforçam que, em geral, a gravidez ocorre sem intercorrências, com um grande número obtendo resultados favoráveis. Aquela parcela de mulheres que apresentam determinadas características ou sofrem de algumas doenças tem maior probabilidade de uma evolução desfavorável, assim, "uma gravidez é considerada de alto risco na presença de algum fator de risco materno ou fetal que afetará adversamente seu resultado" (SCHIRMER; SUMITA; FUSTINONI, 2002, p. 186).

Para Gilbert e Harmon (2002, p. 35), "uma gravidez é considerada de alto risco quando a mãe ou o feto está em perigo significantemente maior de perturbação (morbidade) ou de morte (mortalidade)".

Branden (2000, p. 73) também lembra que embora a gravidez seja um evento biológico normal para a maioria das mulheres, "também pode haver uma situação de alto risco para as gestantes que apresentam condições que ameaçam sua saúde e a do feto, ou distúrbios que interferem no desenvolvimento fetal normal [...]". Assim, precisam ser conhecidos os assim denominados fatores de risco à gestação.

O Ministério da Saúde (BRASIL, 2006) os classifica da seguinte forma: 
-características individuais e condições sociodemográficas desfavoráveis tais como idade menor que 17 e maior que 35 anos; ocupação que requer esforço físico, com carga horária exagerada e exposição a agentes físicos, químicos e biológicos; situação conjugal insegura; baixa escolaridade; condições ambientais desfavoráveis; altura menor que $1,45 \mathrm{~m}$; peso menor que 45 e maior que $75 \mathrm{~kg}$; dependência de drogas lícitas ou ilícitas;

-história reprodutiva anterior que verifique casos de morte perinatal explicada ou inexplicada; recém-nascido com restrição de crescimento intra-uterino, malformado ou pré-termo; abortamento habitual; esterilidade ou infertilidade; intervalo entre partos menor que 2 ou maior que 5 anos; nuliparidade ou multiparidade; histórico de hemorragia ou hipertensão na gestação/parto/puerpério; cirurgia uterina anterior; -doença obstétrica na gestação atual, entre elas alteração da curva de crescimento uterino, número de fetos e volume de líquido amniótico; trabalho de parto prematuro ou pós-maturidade; ganho ponderal inadequado; pré-eclâmpsia/eclâmpsia; amniorrexe prematura; hemorragias na gestação; isoimunização; óbito fetal;

-intercorrências clínicas tais como cardiopatias; pneumopatias; nefropatias; endocrinopatias; hemopatias; hipertensão arterial; epilepsia; doenças infecciosas; doenças auto-imunes; ginecopatias.

Além de proceder à categorização dos fatores de risco à gestação, Sinclair (2002) identifica alguns obstáculos para a busca do cuidado à saúde, como aqueles relacionados a aspectos financeiros, culturais e de gênero. A autora define ainda algumas condições e características que aumentam os riscos de saúde nos anos de reprodução, considerando, entre eles, os dados demográficos; a idade materna (gestação na adolescência ou no final da idade reprodutiva); as questões socioculturais (tanto em relação às questões étnicas e culturais, quanto àquelas 
econômicas); os comportamentos de saúde (principalmente aqueles envolvendo uso de fumo e substâncias químicas, entre elas o álcool, drogas ilícitas e fármacos prescritos); os aspectos nutricionais (como desnutrição, obesidade e distúrbios alimentares, em especial a anorexia e a bulimia); o estresse (geralmente decorrente dos múltiplos papéis exercidos pela mulher na sociedade); as práticas sexuais (que podem ter levado à gestação indesejada ou à contaminação por doença sexualmente transmissível); as condições médicas prévias (em geral referindo-se às doenças crônicas como endocrinopatias e nefropatias); as condições ginecológicas (relacionadas, entre outros, ao câncer ginecológico e seus tratamentos, doença inflamatória pélvica, endometriose, malformações uterinas); os perigos ambientais (causados por agentes patogênicos, substâncias químicas naturais e sintéticas, radiação, substâncias alimentícias, e objetos físicos); a violência contra a mulher (relacionamentos com espancamento, abuso sexual, estupro).

O consumo de álcool destaca-se entre os fatores de risco para a gestação e permanece um assunto atual, principalmente por seu uso ser aceito socialmente. Mesmo que campanhas de educação e orientação durante o pré-natal sejam reiteradas, o consumo de bebidas alcoólicas permanece sendo preocupante, principalmente devido à associação ao abuso de outras drogas ilícitas, ao fumo e à má nutrição (EUSTACE; KANG; COOMBS, 2003). O álcool é reconhecidamente um agente teratogênico, sendo que seu uso na gestação pode causar morte do embrião ou feto, déficit de crescimento intra e pós-natal, malformações, disfunção de vários órgãos e problemas do sistema nervoso central que resultam em baixo quociente de inteligência (QI) e dificuldade de aprendizado; a síndrome alcoólica fetal é a principal causa conhecida de retardamento mental, ultrapassando a síndrome de Down (EUSTACE; KANG; COOMBS, 2003; STREISSGUTH, 1992). 
Os mecanismos para promover a conscientização da população sobre estes riscos têm se mostrado ineficientes, com as estratégias de prevenção agindo de forma evasiva, tanto pela incapacidade dos profissionais de saúde em reconhecer e intervir nos casos de uso e abuso de álcool, como pela dificuldade das gestantes admitirem sua condição de consumidoras (EUSTACE; KANG; COOMBS, 2003).

A Associação de Enfermeiros da Saúde da Mulher, Obstetras e Neonatais (Association of Women's Health, Obstetric and Neonatal Nurses - AWHONN) buscou evidências científicas sobre as práticas da enfermagem dirigidas à prevenção do parto prematuro (MALONI et al., 2003). Ao longo do desenvolvimento do estudo, tornou-se clara a falta de evidências as quais amparassem algumas práticas que supostamente preveniam o parto prematuro. Assim, a pesquisa direcionou-se a diferentes aspectos, como a efetividade das ações educacionais para identificação de sinais e sintomas de trabalho de parto prematuro. Como resultados, foram encontradas fortes evidências de que a educação das gestantes pode mudar uma variedade de resultados de saúde, o que reforça o impacto desta estratégia sobre a redução do risco de baixo peso ao nascimento. Maloni et al. (2003) mostram preocupação com as taxas de gestantes fumantes, já que há comprovação de que o fumo aumenta a incidência de baixo peso ao nascimento e restrição de crescimento intra-uterino, além de estar associado com algumas complicações maternas como infertilidade, gestação ectópica, abortamento, parto prematuro e natimorto. Ressaltam ainda que, apesar da melhora do cuidado perinatal, o número de recém-nascidos de baixo peso ou de extremo baixo peso é maior entre mulheres fumantes, com taxas de mortalidade perinatal duas vezes maior do que entre não-fumantes. 
Conforme Fried (1992), o uso de cigarros durante a gestação foi estabelecido como um agente teratogênico, com a exposição perinatal relacionada a resultados gestacionais negativos, particularmente no que diz respeito ao curso da gestação em si e ao crescimento do feto e da criança. Assim, cita o aborto espontâneo, natimorto, morte perinatal e síndrome da morte súbita do recém-nascido entre outras conseqüências do uso de tabaco. Reforça que o efeito do cigarro sobre o peso ao nascimento depende também da dose, e não é resultado do encurtamento do tempo gestacional. Quando compara gestantes não-fumantes com fumantes, tem-se um aumento na prevalência de $54 \%$ (fumantes leves) e 130\% (fumantes pesadas) de recém-nascidos com peso menor que 2.500g (FRIED, 1992).

Para Maloni et al. (2003), a gestação é considerada o período ideal para usar intervenções que estimulem o abandono do hábito de fumar, pois as mulheres têm uma preocupação maior com sua saúde e, especialmente, com a saúde de seus filhos.

Aaronson (1989) refere que as gestantes devem ser encorajadas a abster-se de fumar e ingerir bebidas alcoólicas, já que o fumo e o álcool estão relacionados a problemas congênitos. Porém, tal abstenção pode ser difícil. Além de ter-se o hábito de usá-las, em geral, há o potencial risco de adição a elas, e, também, grande prevalência nos meios societários das gestantes.

Outro fator de risco preocupante para o desenvolvimento da gestação diz respeito à hipertensão.

A hipertensão na gestação é definida pela constatação de pressão arterial sistêmica superior a 140/90mmHg, ou o aumento de $30 \mathrm{mmHg}$ na pressão sistólica e de $15 \mathrm{mmHg}$ na pressão diastólica, quando os níveis estiverem menores que 140/90mmHg. Para tal definição, a elevação da pressão arterial da gestante deve 
acontecer em pelo menos duas ocasiões, com intervalos de quatro a seis horas (CASHION, 2002). Os distúrbios hipertensivos da gestação, ou a hipertensão induzida pela gestação (HIG), podem ser classificados conforme Gilbert e Harmon (2002), em:

- hipertensão transitória - hipertensão leve que se desenvolve durante a gestação em pacientes previamente normotensas, sem proteinúria* e sem edema patológico\#, podendo acontecer também nas primeiras 24 horas após o parto;

- proteinúria gestacional - desenvolvimento de proteinúria após a $20^{a}$ semana de gestação em pacientes anteriormente sem proteinúria ou hipertensão;

- pré-eclâmpsia - desenvolvimento de proteinúria e hipertensão em pacientes anteriormente normotensas após 20 semanas de gestação ou no puerpério imediato; quando de doença trofoblástica, pode desenvolver-se antes da $20^{\mathrm{a}}$ semana;

- eclâmpsia - desenvolvimento de convulsões ou coma na paciente pré-eclâmptica.

A gestante é considerada portadora de hipertensão crônica se a pressão arterial estiver aumentada antes da gestação ou for diagnosticada antes da $20^{a}$ semana. Também é assim definida a hipertensão que persiste por mais de seis semanas após o parto.

Segundo o Ministério da Saúde (BRASIL, 2000), os fatores de risco para a hipertensão induzida pela gestação são: primeira gestação; diabete mellitus; gestação gemelar; irmã, mãe ou avó com pré-eclâmpsia; hipertensão crônica; préeclâmpsia sobreposta à hipertensão em gestações prévias; hidrópsia fetal; gestação molar; nova paternidade; idade materna acima de 35 anos.

\footnotetext{
* A proteinúria é a concentração de $0,1 \mathrm{~g} / \mathrm{l}(1+$ a $2+$ na fita reagente), em duas amostras aleatórias de urina coletadas com intervalo mínimo de 6 horas. Na amostra de 24 horas de urina, a proteinúria compreende uma concentração de $0,3 \mathrm{~g} / \mathrm{l}$.

* O edema considerado patológico é aquele acúmulo evidente de líquidos na face, nas mãos e região sacra, que não diminui após repouso de 12 horas no leito. Pode também ser caracterizado pelo aumento rápido de peso (mais de $2 \mathrm{~kg}$ em uma semana).
} 
Istvan (1986) lembra ser a hipertensão induzida pela gestação uma alteração que coloca em risco tanto a vida da mãe quanto a do bebê. Apesar das causas da hipertensão não serem bem compreendidas, ela está relacionada a alguns fatores de risco sociodemográficos, como a raça e o número de gestações prévias. Para o autor, deve-se lembrar que, apesar de raramente ser mencionado, são encontradas na literatura evidências que indicam ser o estresse psicossocial um fator contribuinte para a hipertensão crônica. Sugere, por fim, maior investigação desta correlação na gestação.

A identificação de hábitos nocivos à gestação, medidas do peso corporal e a aferição periódica da pressão arterial, bem como a orientação para uma dieta adequada são importantes passos do pré-natalista para a condução de prática educativa e preventiva de comportamentos que possam levar a complicações para a gestação e nascimento.

Na cidade de Porto Alegre, onde foi desenvolvido o estudo, mesmo que $61,34 \%$ das gestantes compareçam a sete ou mais consultas de pré-natal, tem-se ainda uma porcentagem de 10,26\% de recém-nascidos de baixo peso (BRASIL, 2005), índice considerado elevado para os padrões mundiais.

Por todas as razões anteriormente referidas, o estudo e a identificação do perfil psicossocial das gestantes revelam-se como fundamentais na atenção prénatal, especialmente quando se pretende estimular a adesão das mulheres, durante a gestação, a desenvolverem comportamentos que favoreçam uma gestação saudável.

Diante dessas observações, a presente pesquisa visa a contribuir com a assistência pré-natal oferecendo aos profissionais um instrumento traduzido e 
adaptado para a cultura brasileira, construído com a finalidade de caracterizar o bem-estar psicossocial de gestantes.

\subsection{BEM-ESTAR PSICOSSOCIAL E GESTAÇÃO}

O bem-estar humano, conforme a Organização Mundial de Saúde (WHO, 2005), tem múltiplos constituintes, incluindo bens materiais básicos para uma boa vida, liberdade de escolha, saúde, boas relações sociais e segurança. O bem-estar está na extremidade oposta de um continuum de pobreza, que é definida como a privação exacerbada de bem-estar. Os constituintes do bem-estar, conforme experienciados e percebidos pelas pessoas, dependem de situações, refletindo a geografia local, a cultura e circunstâncias ecológicas, idade, gênero e cultura.

Moreira e Sarriera (2006, p. 8) definem o bem-estar "como um sentimento atual, global e prazeroso, mas com projeção futura, originado pela aquisição pessoal de potencialidades e possibilidade de qualidade de vida". Ressaltam, entretanto, que é preciso considerar suas especificidades, relacionadas à integração entre as pessoas, à aprendizagem, ao conhecimento, à mediação social, ao meio natural, à organização na comunidade, e principalmente, à saúde (MOREIRA; SARRIERA, 2006).

Para Reed (1986), em seu estudo inicial sobre a religiosidade e doença terminal, o bem-estar foi definido como a sensação de satisfação com a sua própria vida. Jesse e Reed (2004), em estudo com gestantes, definem o bem-estar psicossocial em termos dos fatores que o compõem: níveis de estresse, níveis de auto-estima e o suporte social do parceiro e outros. Norbeck e Anderson (1989) corroboram esta afirmação e identificam como construtos do bem-estar psicossocial 
o estresse, o apoio social e o desequilíbrio emocional. Estas autoras identificaram, também, a ansiedade e o uso de substâncias químicas como respostas em curto prazo ao estresse na gestação, ambos reconhecidamente nocivos à mãe e ao feto.

Para Curry, Campbell e Christian (1994), autoras que desenvolveram o Prenatal Psychosocial Profile - PPP, os mecanismos pelos quais os resultados da gestação são influenciados por fatores como o estresse, o apoio social e a autoestima não são bem compreendidos, pois até recentemente o modelo teórico propunha que havia uma relação fisiológica entre os fatores psicossociais e os desfechos gestacionais. Esse modelo incluía uma variedade de ligações fisiológicas como mudanças neuroendócrinas, alteração na perfusão uterina e alterações imunológicas. Entretanto, conforme Istvan (1986), a avaliação desses modelos fisiológicos em uma gestação humana mostra-se tecnicamente e eticamente impossíveis.

Ao elaborarem o PPP, as autoras basearam-se em um modelo teórico que propunha uma relação comportamental entre os fatores psicossociais e os resultados da gestação, porém sem desconsiderar as potenciais interligações fisiológicas. O exemplo que citam ao justificarem seu estudo é o de que a baixa auto-estima de uma gestante pode reduzir a sua motivação para fazer pré-natal, limitar sua capacidade de ter relacionamentos de apoio e contribuir para o uso de bebidas alcoólicas. Todos estes comportamentos podem, direta ou indiretamente, influenciar o desfecho da gestação. Além disso, todos têm relevância clínica, pois podem ser modificados durante a gravidez (CURRY; CAMPBELL; CHRISTIAN, 1994).

Esse último modelo foi escolhido pelas autoras para o desenvolvimento do PPP as quais, através de extensa revisão da literatura, buscaram os construtos que 
fossem apropriados para tal e que também fossem compatíveis com a prática clínica das autoras com gestantes de baixa classe socioeconômica. Assim, o estresse, o apoio social e a auto-estima foram selecionados por causa de sua adequação ao modelo e à experiência das autoras, por indicarem respostas comportamentais que influenciam direta ou indiretamente a gestação e por permitirem avaliar o bem-estar psicossocial.

\subsection{ESTRESSE}

Curry, Campbell e Christian (1994), ao buscarem fundamentação para elaborar 0 instrumento PPP, verificaram que a literatura afirmava que o estresse havia sido estudado como uma tentativa de identificar um fator psicossocial que revelasse maior variedade de resultados do que os estudos previamente realizados sobre a ansiedade e os desfechos da gestação. Estudos retrospectivos revisados pelas autoras mostraram correlação entre estresse durante a gestação e prematuridade; e, em três estudos prospectivos, elas encontraram relação entre avaliações do estresse durante a gravidez e baixo peso ao nascer.

O estresse, segundo Helman (2000), foi descrito pela primeira vez por Hans Selye em $1936^{*}$ e, na cultura popular, é difundido como principal metáfora para o sofrimento pessoal e coletivo no final do século XX. O autor diz que no modelo original de Selye, o estresse representa a resposta generalizada do organismo às demandas ambientais; é um mecanismo fisiológico inerente ao organismo que o prepara para a ação e que é acionado quando as demandas assim o exigem.

\footnotetext{
* SELYE, H. A syndrome produced bay diverse nocuous agents. Nature, s.I., v. 138, n.32, s.p., 1936.
} 
Referindo-se aos estudos posteriores de Selye ${ }^{* *}$, o estresse é mediado pelas características individuais, pelo ambiente físico, pelo apoio social disponível, pelas condições financeiras e por questões culturais.

Ao citar Parkes", Helman (2000) lembra que o estresse pode decorrer, também, de situações em geral positivas como uma promoção, o ganho de muito dinheiro ou o nascimento de uma criança, o que envolveria a mudança do estilo de vida do indivíduo.

Istvan (1986) refere que de todas as crenças populares que associam fatores emocionais a disfunções somáticas, as mais encontradas, culturalmente, são aquelas que correlacionam as emoções durante a gestação com anormalidades no parto ou com o recém-nascido. Conforme o autor, o impacto de eventos maternos sobre os resultados reprodutivos é citado no Antigo e no Novo Testamento, encontrados em escritos de médicos da Antiga Grécia, e nos trabalhos de vários estudiosos europeus ao longo da Idade Média até o século passado. Através dos anos, modificou-se a noção de que os efeitos psicológicos na gestação e no parto se manifestariam através da impressão causada na mãe por algum objeto ou evento estressante (como, por exemplo, que a gestante assustada por um cachorro daria à luz uma criança com feições caninas), passando-se a crer que as situações de estresse emocional poderiam ter efeitos adversos não específicos sobre o feto ou o nascimento (ISTVAN, 1986). O autor acredita que o número reduzido de estudos nesta área deve-se às restrições éticas e práticas de estudos experimentais deste fenômeno (o estresse) em humanos, além do entrelaçamento de fatores médicos, comportamentais e sociodemográficos que contribuem para o risco obstétrico.

\footnotetext{
${ }^{*}$ SELYE, H. Forty years of stress research: principal remaining problems and misconceptions. Can. Med. Assoc. J., s.I., v. 115, p. 53-57, 1976.

\# PARKES, C.M. Psycho-social transitions: a field for study. Social Science and Medicine, s.l., v. 5, p. 101-115, 1971.
} 
Bonilla (2002) afirma que alguns autores consideram o estresse como uma condição de exigência, demanda, ou agressão exterior, enquanto outros, consideram que se trata das mudanças fisiológicas, emocionais e de condutas produzidos em um determinado processo, neste caso, a gestação. Durante a gestação, o fator estressante mais importante é a gestação, em si, e a autora acredita ser diferente ao tratar-se da primeira gestação, ao tratar-se de uma adolescente ou de uma mulher considerada idosa para estar grávida, e se a mulher é solteira ou casada; havendo diferença, também, entre os grupos socioeconômicos, e nas diferentes culturas. Porém, afirma que o fator mais relevante é se o filho é desejado ou planejado. Também lembra que a ansiedade produzida é distinta nos três trimestres da gestação e, em geral, é menor no segundo trimestre em comparação ao primeiro e ao terceiro (BONILLA, 2002).

Os laços sociais têm influência na manutenção da saúde e favorecem condutas adaptativas em situações de estresse. Griep et al. (2005), através de revisão de literatura, sugerem que a ruptura de laços sociais afeta os sistemas de defesa do organismo, de tal forma que o indivíduo se torne mais suscetível a doenças.

A gestação está normalmente associada a algum nível de estresse, relacionado a fatores como a antecipação em tornar-se mãe e alterações hormonais. Conforme Tiran e Chummun (2004), as reações são comuns e, se ocorrerem de forma moderada, são desejáveis, pois aumentam a capacidade de enfrentamento da gestante. Entretanto, se os níveis de estresse aumentarem demasiadamente, podem perturbar as atividades diárias da mulher grávida, levando à deterioração da sua saúde e bem-estar, uma vez que ela pode adotar certas estratégias para lidar com situações do dia-a-dia, como o consumo exagerado de alimentos, o sedentarismo e 
o consumo de álcool e fumo. Indiretamente, estas atitudes aumentam ainda mais o estresse e contribuem para maior morbidade e mortalidade perinatal, gerando complicações como pré-eclâmpsia, restrição de crescimento intra-uterino, diabete gestacional, trabalho de parto prematuro, entre outros (TIRAN; CHUMMUN, 2004).

Sob a perspectiva biológica, o estresse é uma reação psico-imune-endócrina na qual existem vias de facilitação e inibição de funções, com intercâmbio contínuo entre os sistemas nervoso central, endócrino e imunológico (ROMERO; FIGUEROA; GARCÍA, 1999). Por variadas razões, a gestação implica em uma tarefa de desenvolvimento psicossocial, ou a uma sucessão de tarefas e objetivos difíceis e exigentes. Romero, Figueroa e García (1999) descrevem que a hiperatividade simpática com descarga de catecolaminas, característica da primeira fase do estresse, pode explicar uma série de complicações na gestação, como o aborto espontâneo, a má nutrição fetal, a restrição de crescimento intra-uterino; a ruptura prematura de membranas e a distócia hipertônica; hipertensão materna.

Ruiz e Fullerton (1999) referem ser a presença de estresse na gestação um fator de risco para o nascimento de bebês de baixo peso. A prevenção do baixo peso ao nascimento tem sido uma das principais iniciativas do Departamento de Saúde dos Estados Unidos, cujos esforços estão voltados para a identificação daquelas mulheres que, durante o pré-natal, possuem maiores riscos de resultados adversos. Esses esforços, mais recentemente, passaram a dar enfoque ao modelo de saúde biopsicossocial, como um preditor mais amplo dos fatores de risco. 


\subsection{APOIO SOCIAL}

Ao escolherem o apoio social como um dos construtos para compor o PPP, Curry, Campbell e Christian (1994) basearam-se em estudos que verificaram que maior apoio social, associado ao fortalecimento do ego e a atitudes positivas, reduzia as complicações gestacionais em mulheres com estresse elevado. Enquanto alguns estudos sugeriam que o apoio social tivesse um efeito protetor para os resultados da gestação, outros afirmavam que o apoio social possui efeito direto sobre a mesma, influenciando as percepções sobre saúde durante a gestação, não só da mulher grávida, como também do companheiro e da família (CURRY; CAMPBELL; CHRISTIAN, 1994).

O apoio da família e de amigos é um recurso valioso há muito associado ao bem-estar psicológico, sendo o apoio social um fator moderador ou protetor dos efeitos do estresse na saúde física e mental (THOITS, 1995). Thoits (1995) afirma ser o apoio social relacionado àquelas funções exercidas para o indivíduo por pessoas significativas, como membros da família, amigos e colegas.

Connelly (1998, p. 198) utiliza a definição de Kahn\# (1979) para apoio social:

"O apoio social é um metaconstruto multidimensional constituído de transações interpessoais que incluem um ou mais dos seguintes: a expressão positiva de como uma pessoa afeta a outra, a afirmação dos comportamentos ou percepções de outra pessoa, e a oferta de auxílio material ou simbólico à outra pessoa."

A autora, em sua pesquisa de pós-doutorado (CONNELLY, 1998), estudou a associação entre esperança, auto-estima e o apoio social em adolescentes, e verificou que o apoio social possui uma variedade de funções, como oferecer

\footnotetext{
\# KAHN, RL. Aging and social support. In: RILEY, B. (ed.). Aging from birth to death: interdisciplinary perspectives. Boulder, CO: Westview, 1979. p. 77-91.
} 
orientação, reforço social e auxílio tangível. Assim, para Connelly (1998), a função ampla do apoio social seria a de promover o desenvolvimento psicossocial, e seu poder embasa-se na sua capacidade de suplementar as experiências de cada indivíduo, pois tem ação protetora e facilita o lidar com crises e adaptar-se a mudanças.

Para Schroevers, Ranchor e Sanderman (2003), há dificuldade, nas pesquisas sobre apoio social, em encontrar um consenso sobre como o apoio social deve ser definido. Para esses autores, existe uma grande variedade de conceitos relacionados (a) ao tipo de apoio (emocional, instrumental, ou de informação), (b) à disponibilidade percebida (expectativas) versus o apoio realmente recebido, e (c) à quantidade versus satisfação com o apoio realmente recebido. Essa distinção faz-se necessária já que incorpora a idéia de que apoio deve adaptar-se às necessidades da pessoa para que seja benéfico.

Freqüentemente, o apoio social é postulado como tendo efeito positivo de proteção ao estresse, ao permitir que seu efeito seja reduzido e, também, facilite seu enfrentamento. Aaronson (1989) refere que a família e os amigos compõem nossos ambientes sociais e que seu apoio pode ser crucial em iniciar ou manter práticas de saúde positivas. Reforça, entretanto, que há necessidade de se distinguir o apoio percebido e o apoio recebido* para que possam ser determinados seus efeitos específicos sobre a saúde ou sobre os comportamentos de saúde.

Os efeitos do apoio social são os mais estudados pela literatura, especialmente os que se referem ao apoio emocional percebido, ou seja, aqueles que compreendem a crença de que amor e cuidado, compreensão e simpatia e/ou estima e valorização por parte das pessoas significativas está disponível (THOITS,

\footnotetext{
"Grifo da autora.
} 
1995). Ainda, esta autora afirma que a percepção ou crença de que este apoio está disponível parece ter uma influência muito mais forte sobre a saúde mental do que o apoio social realmente recebido*.

Brown (1986a), ao se questionar se o apoio social é um construto uni ou multidimensional, refere que a definição de apoio social varia muito entre os pesquisadores. Tal variação vai desde conceitos amplos, como "o apoio é o principal construto para a provisão de relações sociais " até uma visão mais específica de que “apoio é constituído por informação, nurturance", empatia, encorajamento, validação de comportamentos, constructive genuineness ${ }^{\#}$, compartilhamento e reciprocidade, ajuda instrumental e reconhecimento da competência ${ }^{* *, . ~ E m b o r a ~ a ~ p a l a v r a ~ a p o i o ~}$ possua um significado coloquial considerável, é o apoio social que auxilia o indivíduo a obter, reencontrar ou utilizar sua força pessoal durante períodos adaptativos difíceis que demandam maior energia e recursos (BROWN, 1986b), como a gestação. Para Brown (1986a), a dimensionalidade do apoio baseia-se na qualidade, quantidade, fonte e tipo de apoio disponível ou oferecido, bem como na diferenciação do apoio recebido e percebido, e a autora reforça, também, que a distinção entre as pessoas que oferecem o apoio social (parceiro, esposo, ou amigos, familiares, colegas, etc.) é de fundamental relevância.

Thoits (1995) sugere que as pessoas que oferecem apoio reafirmam o senso de identidade da pessoa que recebe esse apoio, através de feedback ${ }^{\#}$ e encorajamento que sustentam a sensação de maestria e competência do indivíduo.

\footnotetext{
"WEISS, R.S. The fund of sociability. Trans-action, s.I., v. 6, p. 36-43, 1969. WEISS, R.S. The provisions of social relationships. In: RUBIN, Z. (ed.) Doing unto others. Englewood Cliffs, NJ, USA: Prentice-Hall, 1974. p. 17-26.

\# Palavras mantidas no idioma original do artigo por não possuírem, em nossa opinião, tradução adequada em português.

${ }^{*}$ COBB, S. Social support as a moderator of life stress. Psychosomatic Medicine, s.l., v. 38, p. $300-$ 314, 1976. PORRIT, D. Social support in crisis: quantity or quality? Social Science and Medicine, s.I., v. $13 \mathrm{~A}$, p. $715-721,1979$.
} 
Assim, as pessoas que oferecem apoio podem encorajar (ou sabotar) as tentativas individuais de determinado comportamento alimentar, de uso de cigarro ou álcool e atividades físicas, ativamente regulando o indivíduo em seus comportamentos de saúde, em sua participação em atividades de saúde e na busca de cuidados médicos.

Embora o apoio social seja visto, em geral, como mediador ou protetor ao estresse, outros mecanismos podem ocorrer. Ou seja, o apoio social afeta, indiretamente, a saúde por estimular, a exemplo na gestação, a adesão das gestantes às práticas de saúde que são benéficas ao crescimento e desenvolvimento fetal bem como à saúde geral da mulher, pois a decisão de alterar seus comportamentos de saúde é reforçada conforme ela percebe e recebe esse apoio (AARONSON, 1989).

Harley e Eskenazi (2006) verificaram, em um grupo de gestantes imigrantes mexicanas nos Estados Unidos, que a alta paridade, a baixa educação e a baixa renda estavam associadas com baixo apoio social, enquanto maior apoio social favorecia melhor qualidade dietética, o uso de vitaminas prescritas durante o prénatal e a diminuição da incidência de fumantes.

Norbeck, Dejoseph e Smith (1996) propuseram um tipo de intervenção de apoio social, realizada por enfermeiras, com gestantes afro-americanas avaliadas como possuidoras de baixo apoio social. O objetivo era a redução da incidência de recém-nascidos de baixo peso. Os resultados obtidos foram de 9,1\% de incidência de baixo-peso ao nascimento nas gestantes que sofreram a intervenção, comparados a $22,4 \%$ de incidência no grupo-controle.

No entanto, é preciso analisar o contexto de vida de cada gestante, assim, independentemente das suas condições psicossociais, mais expressamente em 
relação ao apoio social recebido durante a gestação, pois, Oakley, Rajan e Grant (1990) lembram que o apoio, independentemente de sua origem, dificilmente superará os efeitos cumulativos das desvantagens sociais. Referem que se sabe que a alta taxa de tabagismo entre as mulheres de classes trabalhadoras é, em parte, uma resposta ao estresse de cuidar de uma família em circunstâncias bastante difíceis. Em seu estudo, estes autores encontraram uma relação inversa entre renda familiar e o tabagismo, que também foi associado a menor peso ao nascimento dos bebês de gestantes fumantes $(2.837 \mathrm{~g}$, comparado a $2.994 \mathrm{~g}$ de gestantes não-fumantes).

\subsection{AUTO-ESTIMA}

Para Curry, Campbell e Christian (1994), havia evidência suficiente para relacionar a auto-estima aos resultados da gestação, apesar desta inter-relação não ter sido estudada em profundidade. Em sua fundamentação para escolher a autoestima como um dos construtos componentes do PPP, as autoras citam estudos que relacionam a auto-estima a complicações com recém-nascidos, a valores baixos de Apgar no quinto minuto de vida e a maiores escores de risco obstétrico. Também encontraram pesquisas que relacionaram a maior auto-estima das gestantes ao cuidado pré e pós-natal adequado, a maior satisfação nas suas relações sociais e a sensação de controle sobre sua própria vida. Para as autoras, a auto-estima adequada favorece a adesão a comportamentos de saúde benéficos que causam, direta ou indiretamente, impacto positivo sobre os resultados da gestação.

A auto-estima é a atitude positiva ou negativa em relação a si mesmo; uma avaliação geral que cada um tem de si, da sua importância ou valor. A auto-estima é 
apenas um componente do auto-conceito que Rosenberg define como "a totalidade dos pensamentos e sentimentos do indivíduo em relação a si mesmo como um objeto" (UNIVERSITY OF MARYLAND, 2007).

A auto-imagem é característica própria dos seres humanos e define-se como cada indivíduo vê a si mesmo, em um movimento no qual ele é observador e observado e tem a capacidade de exteriorizar-se para descrever-se, julgar-se e avaliar-se. Considerando-se que, provavelmente, cada indivíduo é a coisa mais importante para si mesmo, como este indivíduo é e como ele se sente em relação a si próprio o afetam profundamente (ROSENBERG, 1965). O autor define autoimagem "como a atitude em relação a um objeto, sendo o termo 'atitude' usado amplamente para incluir fatos, opiniões, valores em relação a si próprio, bem como uma orientação favorável ou não em relação a si mesmo" (ROSENBERG, 1965, p. 5). Considera, ainda, que temos atitudes em relação a objetos e que o self é um objeto em relação ao qual o indivíduo tem atitudes.

Assim, Rosenberg (1965, p. 30) afirma que:

"a auto-estima é a atitude positiva ou negativa em relação a um objeto particular, chamado de self. No entanto, a auto-estima tem duas conotações bastante diferentes. Uma delas, de alta auto-estima é que a pessoa pensa que é 'muito boa'; uma conotação muito diferente daquela em que a pessoa pensa que ela é 'boa o suficiente'. Assim, é possível que um mesmo indivíduo considere-se superior à maioria das outras pessoas, mas sinta-se inadequado em relação a alguns padrões que estabeleceu para si próprio“.

Após o consenso de que a auto-estima é vital à necessidade humana e questionarem a importância de compreender por que as pessoas precisam ter autoestima, Greenberg, Solomon, Pyszczynski, et al. (1992) criaram uma interessante teoria (Terror Management Theory) que propõe que as pessoas são motivadas a manter uma auto-imagem positiva, porque a auto-estima protege-os da ansiedade. A teoria desses autores diz ser a auto-estima o sentimento de que cada ser é um 
objeto de valor primário em um universo cheio de significados. Os indivíduos sustentam sua auto-estima através da manutenção da crença em uma concepção da realidade criada culturalmente (ou seja, a visão cultural geral), procurando alcançar os padrões dos valores estabelecidos por esta visão geral. Assim, do ponto de vista da Teoria do Manejo do Terror,

\begin{abstract}
"as pessoas necessitam de auto-estima porque ela é o principal mecanismo psicológico para proteger os indivíduos da ansiedade que a conscientização de sua vulnerabilidade e mortalidade gera" (GREENBERG, SOLOMON, PYSZCZYNSKI, et al., 1992, p. 913).
\end{abstract}

Esse grupo de estudiosos reforça que a raiz da ligação entre auto-estima e ansiedade reside nas interações primárias dos indivíduos com seus pais e outros agentes culturais de socialização. Através de revisão de literatura, referem que na primeira infância as necessidades de bem-estar, amor e proteção são preenchidos pelos pais, oferecendo à criança virtualmente desprotegida bases primárias de segurança. Com o passar dos anos, os padrões paternos de valor e os sentimentos de segurança são internalizados, e essa associação é reforçada pelas respostas dos outros ao comportamento do indivíduo, ou através de ensinamentos culturais e mitos nos quais os cheios de virtude serão recompensados. Basicamente, afirmam ser o mundo um lugar adverso e que a auto-estima provê proteção contra a ansiedade por ser um pré-requisito para sentir-se amado, seguro e protegido (GREENBERG, SOLOMON, PYSZCZYNSKI, et al., 1992).

Schroevers, Ranchor e Sanderman (2003) acreditam ser a auto-estima um importante recurso pessoal que está relacionado com o funcionamento psicológico. Ao estudarem pacientes com câncer, verificaram que a baixa auto-estima está relacionada a sintomas depressivos, independentemente da presença de apoio social, e os resultados obtidos demonstraram que as relações de apoio e a autoestima possuem papel fundamental no bem-estar psicossocial. 
Thoits (1995), em sua análise e revisão de literatura sobre o estresse, o apoio social e estratégias de coping ${ }^{*}$, afirma que além do próprio apoio social, outros recursos para lidar com o estresse relacionam-se à sensação de controle e de maestria sobre a própria vida, além da auto-estima. As estratégias de coping consistem em tentativas comportamentais ou cognitivas de manejar demandas situacionais específicas que podem ser consideradas além da capacidade do indivíduo de adaptar-se. A autora afirma que a maioria dos pesquisadores crê que as pessoas com maior auto-estima ou controle são mais propensas a usar respostas de coping ativas e centradas no problema; pessoas com baixa auto-estima lidam com situações estressantes de forma mais passiva e evitam se centrarem nas questões emocionais.

Curry, Campbell e Christian (1994), ao criarem o instrumento Prenatal Psychosocial Profile (PPP), adicionaram à Escala de Auto-Estima de Rosenberg (1965) um item que questiona se a gestante acredita ter controle sobre sua própria vida. Thoits (1995) afirma que a percepção de controle sobre circunstâncias da própria vida está inversamente distribuída em relação ao status social. Mulheres, membros de minorias, pessoas não casadas e, especialmente, aqueles com menor grau de instrução ou salários, exibem maior grau de fatalismo ou menor senso de maestria, controle pessoal. Embora menos estudada pelos pesquisadores de estresse, a "auto-estima está distribuída de forma equilibrada em relação ao status social, não havendo também diferenças entre gêneros" (THOITS, 1995, p. 60).

Uma vez que a alta auto-estima e a percepção de controle sobre a própria vida confirmaram, de forma consistente, ser protetores dos efeitos nocivos do

\footnotetext{
* Palavra mantida no idioma original, pela dificuldade de tradução literal para a língua portuguesa. É amplamente utilizada tanto na área da enfermagem, como na área da psicologia e é expressão usada para referir-se ao enfrentamento de determinadas situações, ou como cada indivíduo lida ou adaptase a determinadas situações.
} 
estresse para a saúde, os pesquisadores concluíram que estas características aumentam o uso efetivo de estratégias de coping, variando conforme a vulnerabilidade a diferentes fatores estressores gerados por questões demográficas e sociais (THOITS, 1995).

Raphael-Leff (1997) lembra que, durante a gestação, a liberdade de escolha da mulher é reduzida, constantemente ela está compartilhando seu corpo com outro ser que está ali, mesmo nos momentos mais íntimos. Assim, a rápida mudança de forma, a perda de sua imagem corporal, as alterações dos papéis na família e na sociedade geram desagregação do self, com impressões por vezes distorcidas da sua auto-imagem e auto-estima.

Para Curry, Burton e Fields (1998), a auto-estima tem o potencial de tanto influenciar a percepção do estresse, como de ser afetada por eventos estressantes. Assim, uma pessoa com maior auto-estima e maior controle sobre sua vida vê os eventos da vida como não tão estressantes, resultando em uma relação inversa entre estresse e auto-estima. De forma semelhante, a auto-estima tem potencial de aumentar a percepção de apoio, bem como legitimar este apoio.

Por todas as razões acima referidas, o estudo e a identificação do perfil psicossocial das gestantes possibilitam a prevenção e/ou detecção de comportamentos nocivos à saúde da mãe e do feto e revelam-se como fundamentais na atenção pré-natal. Portanto, a disponibilidade de um instrumento prático e específico para avaliação do perfil psicossocial de gestantes virá favorecer o trabalho dos profissionais inseridos no atendimento pré-natal bem como contribuir na qualidade da assistência materno-infantil. 


\section{OBJETIVOS}

Diante da necessidade do conhecimento sobre o perfil psicossocial das gestantes para redução de riscos à saúde materna e fetal, a presente pesquisa visa a oferecer aos profissionais de saúde envolvidos na assistência pré-natal um instrumento prático e eficaz para a caracterização do bem-estar psicossocial de gestantes.

\subsection{OBJETIVO GERAL}

Adaptar a Escala Prenatal Psychosocial Profile (PPP) para ser usada em gestantes brasileiras e testar suas propriedades psicométricas em uma amostra de gestantes residentes em Porto Alegre (RS).

\subsection{OBJETIVOS ESPECÍFICOS}

- Realizar a adaptação transcultural da Escala Prenatal Psychosocial Profile (PPP) para uso no Brasil.

- Avaliar a confiabilidade da versão adaptada do Prenatal Psychosocial Profile (PPP), verificando a estabilidade e a consistência interna de suas subescalas em uma amostra de gestantes residentes em Porto Alegre (RS).

- Avaliar a validade de face, conteúdo e de construto da versão adaptada do Prenatal Psychosocial Profile (PPP) em uma amostra de gestantes residentes em Porto Alegre (RS). 


\section{REFERENCIAL TEÓRICO-METODOLÓGICO}

\subsection{ADAPTAÇÃO TRANSCULTURAL DE INSTRUMENTOS DE MEDIDA}

Os instrumentos de coleta de dados, para serem efetivamente usados em nosso meio, devem passar por um processo rigoroso de tradução, adaptação e validação. Conforme Alexandre e Guirardello (2002) enfatizam, a adaptação de um instrumento para outro idioma é um processo complexo devido às diferenças culturais que não permitem que se faça uma simples tradução.

Segundo Guillemin (1995), é necessário lembrar a distinção entre a cultura e o idioma de diferentes países ao proceder-se à tradução e adaptação de um instrumento de coleta de dados. Assim, é necessário ser rigoroso com a adaptação cultural para além da simples tradução, ajustando o instrumento para palavras e contextos culturais, por vezes transformando completamente alguns itens para capturar um mesmo conceito (GUILLEMIN, 1995; SPERBER, 2004).

Sperber (2004), Beaton et al. (2000), Bullinger et al. (1998), Herdman, FoxRushby e Badia (1997) propõem uma série de métodos para proceder à tradução e adaptação cultural que, em sua essência, assemelham-se.

Neste estudo foi seguida a proposta de Beaton et al. (2000), a qual prevê várias etapas metodológicas, sejam elas: a tradução, a síntese, a back translation, a revisão por um comitê de especialistas, o pré-teste e a verificação das propriedades psicométricas. 


\subsubsection{Tradução}

Sugere-se que a tradução direta seja realizada por pelo menos dois indivíduos que dominem bem o idioma original e aquele para o qual o instrumento será traduzido. Assim, ambas as versões podem ser comparadas e evitam-se maiores discrepâncias que podem causar ambigüidades na segunda versão. Devese procurar um consenso entre os dois tradutores, através da discussão entre os mesmos (Beaton et al., 2000).

\subsubsection{Síntese}

Os dois tradutores e uma terceira pessoa envolvida no processo procuram sintetizar os resultados das traduções. Trabalhando com o instrumento original e as versões de cada tradutor, a equipe deverá produzir um único instrumento final, no qual haja consenso e não concessões de um com o outro tradutor (Beaton et al., 2000).

\subsubsection{Back translation}

A partir da síntese obtida, outros dois tradutores que não conhecem a versão original do instrumento, farão nova tradução para o idioma original do mesmo. Esta é uma das etapas de validação do instrumento, que verifica se a versão obtida reflete o mesmo conteúdo da versão original. Em geral, esta etapa permite verificar as inconsistências e os erros conceptuais feitos durante a tradução. Os dois tradutores que realizarem a back translation devem ter como língua-mãe aquela do original do instrumento e, preferentemente, não devem ter maiores conhecimentos dos conceitos a serem explorados, nem serem da área da saúde (Beaton et al., 2000).

É sugerido que a versão final da back translation seja submetida à avaliação do autor do instrumento (Beaton et al., 2000). 


\subsubsection{Comitê de especialistas}

A composição desse comitê é preconizada como crucial para obter-se a plena adaptação cultural do instrumento. Devem fazer parte do mesmo pesquisadores que tenham conhecimentos da área de saúde, de metodologia, de lingüística e que conheçam bem os dois idiomas envolvidos. O comitê deverá obter consenso quanto à equivalência semântica, idiomática, funcional e conceptual (Beaton et al., 2000).

Conforme Schmidt e Bullinger (2003), Beaton et al. (2000) e Ciconelli (1997), entre outros autores:

- a equivalência semântica refere-se à equivalência do significado das palavras, ou à correta tradução de itens e conceitos, e deve responder a perguntas como "as palavras querem dizer a mesma coisa?", "há significados diferentes atribuídos a um determinado item?", "houve dificuldades gramaticais na tradução?";

- a equivalência idiomática refere-se a expressões coloquiais ou idiomáticas que, em geral, são difíceis de serem traduzidas, e o comitê de especialistas deve procurar expressões equivalentes no idioma-alvo;

- a equivalência cultural ou experimental refere-se à obtenção de coerência entre as experiências diárias do país ou cultura de origem do instrumento com aquelas do país ou cultura para o qual o instrumento está sendo adaptado, ou seja, é preciso verificar se determinado item possui contexto semelhante na população-alvo;

- a equivalência conceitual refere-se a verificar se determinadas palavras ou expressões possuem significado conceitual semelhante, ou mesmo se possuem a mesma importância em diferentes culturas, apesar de se equivalerem semanticamente. 
O papel do comitê de especialistas é o de consolidar todas as versões do instrumento e definir aquela que será a versão a ser submetida ao pré-teste (Beaton et al., 2000).

\subsubsection{Pré-teste}

De posse da versão obtida pelo comitê de especialistas, o instrumento deverá ser aplicado a cerca de 30 a 40 sujeitos que fazem parte da população-alvo a ser pesquisada. Cada sujeito completa o instrumento e é entrevistado para verificar o que ele acredita que cada item e cada resposta significam. Deve-se verificar a proporção de não-respostas. Além disso, alguns testes estatísticos devem ser aplicados para comprovar a adaptação do instrumento (Beaton et al., 2000).

\subsubsection{Verificação das propriedades psicométricas}

Após o processo de adaptação transcultural do instrumento, além de Beaton et al. (2000), Sperber (2004), Bullinger et al. (1998), Herdman, Fox-Rushby e Badia (1997) e Guillemin (1995) também apontam para a necessidade de avaliação das propriedades psicométricas do mesmo, a fim de verificar se as características do instrumento original foram mantidas. Portanto, a versão final do instrumento traduzido e adaptado deve reter tanto as características de cada item, assim como as correlações do item com a escala e a consistência interna, além das características de confiabilidade e de validade dos resultados obtidos. A versão adaptada deverá apresentar performance semelhante à original (Beaton et al., 2000).

\subsubsection{CONFIABILIDADE}

A confiabilidade é um aspecto fundamental para avaliar a qualidade de um instrumento e, ao desenvolver-se uma escala, refere-se à consistência interna da mesma, ou seja, se os itens agrupam-se e medem o mesmo fator (CHWALOW, 
1995; POLIT; HUNGLER, 1997). A confiabilidade de uma medida refere-se à extensão na qual a variabilidade medida em um escore reflete o verdadeiro escore, em vez de um erro aleatório; ou seja, até que ponto a medida oferece resultados acurados ou consistentes (WARE; GANDEK, 1998, p. 951). Conforme Chwalow, (1995) e Polit e Hungler (1997), a confiabilidade deve ser verificada pela estabilidade, consistência interna e equivalência.

A - Estabilidade

A estabilidade de uma medida refere-se a quanto os mesmos escores podem ser obtidos quando o instrumento é aplicado à mesma pessoa em ocasiões isoladas (POLIT; HUNGLER, 1997; CHWALOW, 1995). A avaliação da estabilidade é derivada do teste e reteste, em que se verifica a reprodutibilidade do instrumento, se for aplicado em um intervalo pequeno de tempo.

B - Consistência Interna

Idealmente, escalas elaboradas para medir um atributo são compostas por uma série de itens que avaliam somente este atributo e nada mais. Pode-se dizer que um instrumento tem consistência interna quando seus itens estão todos medindo a mesma característica (POLIT; HUNGLER, 1997). A consistência interna é determinada com uma única aplicação do instrumento, através de indicadores como o alfa de Cronbach, com o qual se verifica a homogeneidade dos itens de modo que meçam as mesmas dimensões (CHWALOW, 1995).

O coeficiente alfa de Cronbach é baseado no número de itens de uma escala e a homogeneidade de cada item, que é definida como a média de todas as correlações entre os itens da escala. Esta homogeneidade reflete até que ponto os itens têm uma variância similar e indica a consistência interna da mensuração, 
independente do número de itens (WARE; GANDEK, 1998, p. 951). Os autores sugerem um nível mínimo de confiabilidade de 0,70.

C - Equivalência

A verificação da equivalência para estimar a confiabilidade, usada principalmente quando diferentes observadores ou avaliadores estão usando um instrumento para medir o mesmo fenômeno, procura determinar a consistência ou equivalência do instrumento em manter as medidas dos mesmos traços nos mesmos sujeitos. Esta abordagem é essencialmente usada para verificar a confiabilidade de instrumentos observacionais (POLIT; HUNGLER, 1997), o que não é o caso do PPP.

\subsubsection{RESPONSIVIDADE}

A responsividade é verificada quando o instrumento apresenta a capacidade de detectar mudanças de um determinado fenômeno em indivíduos ou grupos (FAYERS; MACHIN, 2000; GUILLEMIN, 1995). Assim, a responsividade avalia se há mudanças entre os sujeitos de um mesmo grupo após um período maior de tempo (em comparação ao tempo em que é verificada a reprodutibilidade), e é constatada através do teste e pós-teste.

\subsubsection{VALIDADE}

A validade de um instrumento evidencia se o que está sendo medido é o que se pretende medir, ou seja, afirma-se que um instrumento é válido se de fato mede o que supostamente deve medir (PASQUALI, 2001; CHWALOW, 1995; GUILLEMIN, 1995). Pode-se também dizer que estudos de validade aumentam a compreensão do significado da diferença ou da mudança de um resultado medido por um instrumento (GANDEK; WARE, 1998). 
Para Fayers e Machin (2000, p.45), a "validação de instrumentos é o processo que determina se há base para acreditar-se que um instrumento mede aquilo que tem a intenção de medir e que é útil para a intenção a que se propõe”.

Pasquali (2001) afirma que, após a elaboração de um instrumento, a verificação da legitimidade da representação dos construtos é feita através da análise fatorial, que procura identificar nos dados os construtos previamente selecionados para o instrumento. O autor esclarece que a análise fatorial explica as correlações entre os itens de uma escala como resultantes de variáveis-fonte (ou construtos) que são a causa das covariâncias, ou intercorrelações destes itens.

Entretanto, para Pasquali (2001), a análise fatorial nem sempre é compatível com a realidade dos fatos, pois assume que as respostas dos sujeitos são determinadas por uma relação linear dos itens com traços latentes. Assim, diante das dificuldades, psicometristas recorrem a outras técnicas para demonstrar a validade dos instrumentos, sendo estas reduzidas a três categorias: validade de construto, validade de conteúdo e validade de critério (PASQUALI, 2001; GANDEK; WARE, 1998; POLIT; HUNGLER, 1997; CHWALOW, 1995).

A - Validade de Construto

Pasquali (2001) cita o artigo de Cronbach e Meehl ${ }^{\star}$, de 1955, no qual esses autores procuram clarear a noção confusa de construto e definem a validade de construto como a característica de um teste, enquanto mensuração de um atributo ou qualidade. Para Pasquali (2001), conceitos ou construtos só podem ser pesquisados cientificamente se forem passíveis de representação comportamental adequada, senão serão conceitos metafísicos.

\footnotetext{
* CRONBACH, L.J.; MEEHL, P.E. Construct validity in psycholocal tests. Psychological Bulletin, 52, 281-302, 1955.
} 
Gandek e Ware (1998, p.953) definem a validade de construto como "um processo no qual a validade é avaliada em termos da extensão na qual a medida correlaciona-se com as variáveis de uma maneira consistente com a teoria". Dizem ainda que, ao testar a validade de construto, hipóteses são feitas baseadas na teoria e na literatura, assim, espera-se que a validade seja corroborada quando as associações confirmam a hipótese.

Guillemin (1995) afirma que a validade de construto é a propriedade do método de mensuração que mede corretamente o construto subjacente, que pode conter vários atributos. É avaliado internamente verificando-se a validade fatorial, quando os itens usados para mensurar o mesmo atributo correlacionam-se melhor um com o outro do que com itens medindo outros atributos (análise fatorial); e também pela consistência interna, quando vários itens medindo o mesmo atributo tendem a fornecer a mesma informação e assim se correlacionam de perto um com o outro. Externamente a validade de construto é avaliada através da validade convergente, na qual o construto deve ser correlacionado com variáveis similares que mensurem o mesmo fenômeno. Quando não há essa correlação, chama-se de validade divergente.

Em material produzido por uma força de trabalho que discutiu as práticas de pesquisa dos instrumentos de medida de qualidade de vida, o coordenador e relator deste grupo, Mphil (2001), afirma que a convergência com outros instrumentos que acreditamos ter maior credibilidade pode sugerir redundância de instrumentos. Além disso, alguns instrumentos possuem influência desproporcional sobre o desenvolvimento de outros, de forma que a convergência pode ser um artefato do desenvolvimento comum dos instrumentos. 
Conforme Curry, Burton e Fields (1998) sugerem, a validade de construto do PPP pode ser avaliada verificando-se se há correlação ou não entre suas subescalas, de acordo com o que a literatura descreve. A conexão proposta pela teoria é de que maior estresse deve correlacionar-se negativamente com apoio social e auto-estima, e que maior apoio social deve correlacionar-se positivamente com auto-estima.

B - Validade de conteúdo

A validade de conteúdo refere-se à adequação do conteúdo de um instrumento, em termos do número e amplitude das questões individuais que ele contém (FAYERS; MACHIN, 2000). Como melhor explicam Gandek e Ware (1998), a validade de conteúdo examina a extensão na qual um instrumento ou questionário representa o universo dos conceitos ou domínios e, assim, se a medida oferece uma amostra adequada do conteúdo de um construto.

A validade de conteúdo de um instrumento é baseada necessariamente no julgamento (POLIT; HUNGLER, 1997). Não há uma totalidade de métodos objetivos que assegurem a adequação da abrangência do conteúdo de um instrumento, porém a validade de conteúdo envolve o exame crítico da estrutura básica do instrumento, uma revisão dos procedimentos utilizados para desenvolvê-lo e também a sua aplicabilidade para a questão de pesquisa (FAYERS; MACHIN, 2000).

Fayers e Machin (2000) afirmam ser a validade de face um aspecto da validade de conteúdo. Para Streiner e Norman (1995), a validade de face simplesmente indica se, em face ao instrumento, o mesmo parece avaliar as qualidades desejadas, enquanto a validade de conteúdo consiste em julgar se o instrumento reúne todos os conteúdos ou domínios relevantes. 
Conforme Dini (2000, p. 32), "a validade de face verifica se o instrumento aparenta estar medindo aquilo para o qual foi projetado"; enquanto a validade de conteúdo "diz respeito à relevância de cada item do instrumento para a medição do tema abordado".

Assim, a validade de conteúdo e a validade de face são obtidas através do julgamento do comitê de especialistas durante o processo de adaptação e tradução, quando conferem, igualmente, ao instrumento equivalência semântica, idiomática, cultural e conceitual.

C - Validade de critério

A validade de critério é a "abordagem pragmática do instrumento na qual os pesquisadores procuram estabelecer relações entre os escores do instrumento em questão, com algum critério externo" (POLIT; HUNGLER, 1997, p. 301). Os testes de validade de critério avaliam se os escores estão sistematicamente relacionados a um ou mais critérios de resultados, usando medidas e dados independentes da escala em questão; assim, verifica-se se a qualidade do método de medida corresponde a outra observação que mediu corretamente o mesmo fenômeno (GANDEK; WARE, 1998; GUILLEMIN, 1995).

Um pré-requisito para a avaliação da validade de critério é a disponibilidade de um critério confiável e válido com o qual as medidas do instrumento em questão possam ser comparadas. Não foi encontrado outro instrumento que pudesse ser considerado como medida verdadeira e confiável (padrão-ouro) para todas as subescalas do PPP. Assim, em outro estudo, no futuro, a validade de critério deverá ser verificada através da validade preditiva, com a qual instrumentos podem ser testados por predizerem algum desfecho clínico (GANDEK; WARE, 1998). No caso do PPP, prematuridade, baixo peso ao nascer e depressão pós-parto, por exemplo. 


\subsection{MÉTODO}

\subsubsection{Etapas da adaptação transcultural do PPP}

Para a tradução e adaptação do Perfil Psicossocial do Pré-natal-PPP foram observadas todas as seis etapas metodológicas preconizadas por Beaton et al. (2000) explicitadas anteriormente (4.1), e que têm seu desenrolar descrito no capítulo de Resultados e Discussão.

Antes de se iniciar o processo de adaptação transcultural do PPP, entrou-se em contato com a autora principal do PPP, Mary Ann Curry, através de correio eletrônico, para obtenção da autorização para realizar a tradução e adaptação do PPP e para ter acesso à sua versão original. A autora autorizou a tradução, adaptação, validação e uso da escala no Brasil com a condição de que os resultados obtidos lhe fossem encaminhados (ANEXO B).

\subsubsection{Procedimentos de coleta de dados}

\subsubsection{LOCAL DO ESTUDO}

O local de estudo foi a cidade de Porto Alegre, Rio Grande do Sul, nos ambulatórios de pré-natal de Unidades Básicas de Saúde (UBSs) do município. Foram coletados dados em dez UBSs, pertencentes a todas as sete Gerências Distritais de Saúde do município. Três dessas unidades estavam localizadas em regiões centrais da cidade e as demais na periferia de Porto Alegre (RS).

\subsubsection{POPULAÇÃO-ALVO E AMOSTRA}

A população foi composta por gestantes que freqüentaram consultas de prénatal em UBSs de Porto Alegre, maiores de 18 anos, com idade gestacional entre 12 e 40 semanas, e que aceitaram participar da pesquisa, no período de novembro de 2006 a junho de 2007. 
Fizeram parte da amostra 241 gestantes que possuíam as características acima definidas e que consultaram nos ambulatórios de pré-natal das UBSs. Elas foram selecionadas de forma aleatória, após estratificação das Gerências Distritais.

Contou-se com o auxílio de sete acadêmicos da Escola de Enfermagem da Universidade Federal do Rio Grande do Sul que já haviam cursado a disciplina de Enfermagem no Cuidado à Mulher. O treinamento para a coleta de dados foi realizado em encontros entre a pesquisadora e os acadêmicos para esclarecimentos dos objetivos da pesquisa, orientações sobre os construtos que são avaliados através do PPP, familiarização com os instrumentos de coleta de dados, maneiras de abordagem das gestantes e de conduta durante a aplicação do instrumento de modo a não interferir nas respostas. Além disso, cada acadêmico recebeu um Manual de Orientações para a coleta dos dados (APÊNDICE A).

A abordagem das gestantes para convidá-las a participar da pesquisa aconteceu durante as consultas de pré-natal, que estavam previamente agendadas nas Unidades de Saúde. A aplicação dos formulários e a consulta aos prontuários para levantamento de dados sociodemográficos e clínicos aconteceram nesse momento, sendo por vezes interrompida a aplicação do instrumento para a consulta de pré-natal, sendo retomada logo após. Não houve necessidade de agendamento de um segundo encontro com a gestante. Os formulários para verificação da estabilidade e da responsividade foram preenchidos através de contato telefônico.

\subsubsection{INSTRUMENTOS DE COLETA DE DADOS}

A - Perfil Psicossocial do Pré-natal

O Perfil Psicossocial do Pré-natal, Prenatal Psychosocial Profile (PPP), instrumento a ser validado neste estudo, conforme descrito anteriormente é uma escala do tipo Likert, com 44 itens divididos em quatro subescalas. 
A subescala de estresse tem em seu cabeçalho uma explicação de que vários fatores podem causar estresse e preocupação. Ela é composta de 11 frases às quais a gestante deve responder o quanto cada uma das situações explicitadas lhe causa estresse. As sentenças relacionam problemas do dia-a-dia das pessoas, como preocupações financeiras com alimentação, transporte; contas por pagar; problemas de moradia; problemas relacionados à família; a perda recente de alguém especial; a gestação atual; situações de abuso ou violência; problemas com álcool e drogas; problemas com o trabalho ou com amigos; sentir-se sobrecarregada. As respostas possíveis (e respectivos valores atribuídos a elas) são: 'nenhum estresse' (1), 'algum estresse' (2), 'estresse moderado' (3), e ‘estresse intenso' (4). Os escores podem variar de 11 a 44, maiores valores significam maior estresse.

A subescala de avaliação do apoio social repete a mesma série de frases duas vezes, pois verifica o apoio social recebido do companheiro e de outras pessoas. A primeira seqüência de frases só deve ser preenchida por aquelas gestantes que têm companheiro e a segunda, por todas as gestantes. Ambas as subescalas têm 11 afirmações sobre situações de apoio, como compartilhar vivências; ajudar a manter o ânimo; ajudar a sair de situações difíceis; mostrar interesse em atividade diárias; sair da rotina para fazer coisas importantes; permitir falar de coisas pessoais; demonstrar que valoriza o que é feito para ele/elas; tolerar altos e baixos; levar a sério preocupações; dizer coisas que tornam a situação clara e fácil de ser compreendida; deixar claro que estará por perto. As respostas são dadas através de uma escala de 1 a 6 , com o valor 1 correspondendo à 'muito insatisfeita' e o valor 6 correspondendo à 'muito satisfeita'. A gestante pode, assim, graduar a satisfação com o apoio que percebe receber de seu companheiro e/ou de 
outras pessoas. Os escores variam de 11 a 66, maiores valores indicam maior satisfação com o apoio social recebido do companheiro e/ou de outras pessoas.

A subescala de auto-estima também é composta por 11 itens. O cabeçalho explica que todos nós carregamos conosco algum tipo de imagem própria e que as afirmações da subescala são frases que, em geral, as pessoas usam para se descreverem. Assim, a gestante deve marcar se concorda ou não com as sentenças, e as respostas possíveis (e seus respectivos escores) são: 'concordo completamente' (1), 'concordo' (2), 'discordo' (3), e 'discordo completamente' (4). As frases referem-se a sentir que tem valor e qualidades; sentir-se fracassada; ser capaz de fazer as coisas tão bem quanto outras pessoas; não ter do que orgulharse; ter atitude positiva consigo mesma; sentir-se satisfeita consigo mesma; ter mais respeito por si mesma; sentir-se inútil; achar que não é boa que chega; achar que controla a própria vida. Uma vez que algumas sentenças estão redigidas propositadamente de forma negativa, é previsto que as respondentes se sintam confusas no momento de preencher o instrumento e, assim, pensem melhor ao escolher suas respostas. Ao somar os escores, é necessário que as frases redigidas de forma afirmativa (ou seja, os itens A, B, D, F, G e K) sejam computadas de forma reversa, uma vez que maiores escores significam maior auto-estima. Os valores totais possíveis variam de 11 a 44 .

B - Dados de identificação, clínicos e obstétricos

Procedeu-se também à coleta de dados no prontuário e nas carteiras de prénatal das gestantes, buscando dados de identificação, como idade, escolaridade e telefone para contato (relevante para a aplicação de pós-teste e reteste); dados obstétricos (idade gestacional, data da última menstruação, número de gestações, paridade, número de partos vaginais, cesáreas e abortos, número de consultas de 
pré-natal); e dados clínicos (peso no início da gestação, peso no dia da coleta de dados, valores de pressão arterial no início do pré-natal e no dia da coleta de dados e altura uterina no dia da coleta de dados) (APÊNDICE B).

\subsection{PROCEDIMENTOS DE ANÁLISE}

As etapas para análise de dados, conforme Grady, Newman e Vittinghoff (2003), compreendem vários passos para que se possa proceder à conversão dos formulários preenchidos em uma base de dados que permita a análise estatística.

O software de escolha para a elaboração de base de dados, gerenciamento de dados e análise estatística neste estudo foi o Statistical Package for the Social Sciences $\left(\mathrm{SPSS}^{\odot}\right)$, em sua versão 10.0 para Windows ${ }^{\odot}$.

Os autores acima referem como etapas do gerenciamento de dados os passos que se seguem, usados na íntegra neste estudo:

-definir ou codificar cada variável, atribuindo-Ihe nome e formato e, também, definindo valores permitidos (APÊNDICE C);

-montar a base de dados e o dicionário de dados do estudo;

-testar os procedimentos de gerenciamento de dados antes de iniciar o estudo;

-entrar os dados, identificar e corrigir erros;

-registrar modificações nos dados originais;

-fazer cópias de segurança regularmente;

-criar uma base de dados para análise;

-arquivar e armazenar os dados originais, a base de dados final e as análises do estudo. 
Foi utilizada a estatística descritiva para caracterização da amostra e também para demonstração de valores de média, mediana, desvio-padrão e amplitude de variação dos resultados. Para a testagem das propriedades psicométricas da versão adaptada do PPP e aplicada em uma amostra de gestantes de Porto Alegre (RS), os testes estatísticos usados foram o Teste t para amostras pareadas para avaliação da estabilidade do instrumento (reprodutibilidade) e também para a avaliação da responsividade; o coeficiente de Alfa de Cronbach para verificação da consistência interna; a análise fatorial para verificação da validade teve as cargas fatoriais extraídas através do método de rotação VARIMAX; o Coeficiente de Correlação de Pearson para a verificação da validade de construto. O nível de significância adotado foi de 0,05 . Não houve dados perdidos por preenchimento incorreto de instrumentos ou por número elevado de não-respostas (20\% dos itens) por parte de uma mesma participante.

\subsection{PROCEDIMENTOS ÉTICOS}

O projeto foi encaminhado, avaliado e aprovado (ANEXO C) pelo Comitê de Ética da Secretaria Municipal de Saúde de Porto Alegre, que está registrado no Conselho Nacional de Ética em Pesquisa, com última renovação em setembro de 2005. Havia a intenção inicial de proceder-se também à tradução, adaptação transcultural e validação de outro instrumento de coleta de dados (Spiritual Perspective Scale), porém, por questões de viabilidade, este projeto foi abandonado, devendo ser retomado no futuro.

Seguindo as diretrizes internacionais de ética em pesquisa, foram incorporarados ao estudo, sob a ótica do indivíduo e das coletividades, os quatro 
referenciais básicos da bioética: autonomia, não maleficência, beneficência e justiça, para assegurar os direitos e deveres que dizem respeito à comunidade científica e aos sujeitos da pesquisa.

O termo de consentimento livre e esclarecido (APÊNDICE D), mantido conforme avaliado e aprovado pelo Comitê de Ética em Pesquisa, foi fornecido e assinado por todas as respondentes, após leitura em conjunto com a pesquisadora ou auxiliares de pesquisa. Procurou-se manter uma linguagem acessível, expondo às participantes a justificativa, os objetivos, os procedimentos de pesquisa, os possíveis desconfortos e riscos, e quais os benefícios esperados com o estudo. Foi mantida a possibilidade de esclarecimentos antes e durante a pesquisa sobre a metodologia, bem como a liberdade das participantes de recusar ou retirar o consentimento, sem qualquer tipo de penalização. Igualmente, manteve-se, também, a garantia de sigilo e privacidade, esclarecendo que os dados serão utilizados para fins de pesquisa exclusivamente e que somente serão divulgados através da manutenção do anonimato das respondentes.

Conforme sugestão do avaliador do Comitê de Ética, a pesquisadora procurou inteirar-se do fluxograma de atendimento e encaminhamento de pacientes com alterações emocionais e/ou psicológicas, já que, segundo seu parecer, as questões levantadas pelo instrumento poderiam causar algum tipo de comoção interna nas gestantes (APÊNDICE E). A coleta de dados não causou qualquer tipo de reação inesperada nas gestantes e não houve necessidade de encaminhamento de nenhuma gestante aos serviços da área de Saúde Mental. 


\section{RESULTADOS E DISCUSSÃO}

\subsection{TRADUÇÃO PARA A LÍNGUA PORTUGUESA E ADAPTAÇÃO TRANSCULTURAL DO PPP}

\subsubsection{Tradução e adaptação transcultural do PPP}

Como a pesquisadora possui proficiência no idioma original do instrumento, o inglês, realizou a tradução inicial do mesmo. Enviou, em seguida, a versão original do PPP para duas enfermeiras obstétricas, doutoras em enfermagem e com domínio do idioma original, que fizeram suas traduções individualmente. A pesquisadora e as duas doutoras reuniram-se para avaliação dessas traduções e comparação com o instrumento original. Durante a discussão e arrazoamento para diferentes escolhas de expressões e/ou palavras, levou-se em consideração que as doutoras são moradoras da cidade de Ribeirão Preto (SP) e o instrumento será validado na cidade de Porto Alegre (RS), onde a pesquisadora reside, bem como manteve-se em pauta as condições socioeconômicas e o nível de escolaridade da população respondente da escala. Assim, chegou-se a um consenso com obtenção da síntese dos resultados de uma versão na língua portuguesa.

Em uma segunda etapa da síntese, a pesquisadora solicitou a duas outras enfermeiras obstétricas, doutoras, que também possuem domínio do idioma inglês, que procedessem à avaliação do instrumento original e da síntese obtida pelo grupo anterior. Esse comitê de especialistas reuniu-se com a pesquisadora para amplo debate sobre a versão em português, especialmente em relação às equivalências (semântica, idiomática, cultural e conceitual) da síntese com o instrumento original. 
Uma vez obtido consenso; no qual foram realizadas pequenas mudanças relacionadas à troca de palavras de uso mais comum na população; a versão na língua portuguesa foi considerada apropriada para ser submetida à back translation.

A versão em português, consolidada pelo comitê de especialistas, foi encaminhada para duas tradutoras que não conheciam a versão original do instrumento, para a back translation. Ambas não têm como língua-mãe o idioma original do instrumento, porém são profissionais da área de letras, e, conforme sugerido pela literatura, não são relacionadas à área da saúde e não tinham maior conhecimento sobre os conceitos explorados pelo instrumento. Após fazerem suas traduções individualmente, houve um encontro entre as duas tradutoras, sem a presença da pesquisadora, no qual obtiveram o consenso de uma única versão traduzida novamente para o idioma original (ANEXO D).

Antes de enviar para a autora do instrumento a versão final da back translation obtida por consenso entre as tradutoras, foram realizados encontros da pesquisadora com um terceiro grupo, agora composto por três enfermeiras obstétricas, também doutoras e com domínio do idioma inglês, para que fosse obtida a consolidação da versão final (APÊNDICE F). Avaliou-se o instrumento na versão original, a versão traduzida para o português e a back translation, para a determinação das validades de conteúdo e de face. Houve consenso deste comitê de especialistas quanto à equivalência da versão em português. Portanto,a versão da back translation foi considerada adequada para encaminhamento à principal autora do PPP, Mary Ann Curry, o que foi feito através de correio eletrônico, sendo aprovada sua versão pela autora (ANEXO E).

As etapas seguidas para realizar a tradução e adaptação encontram-se esquematizadas na Figura 1. 


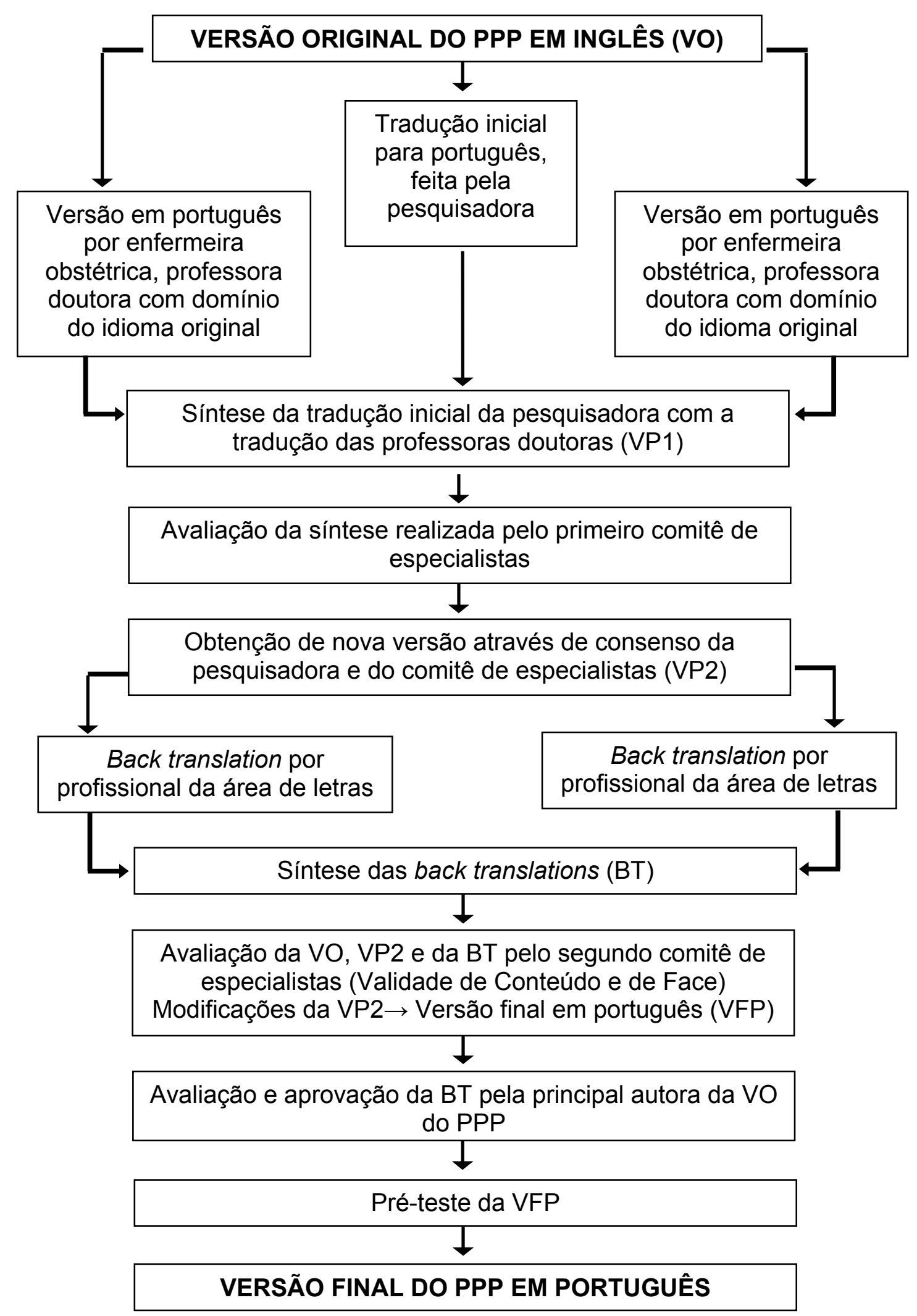

Figura 1 - Etapas do processo de tradução e adaptação do PPP seguidas neste estudo 


\subsubsection{Pré-teste do PPP, versão em português}

Inicialmente o PPP, versão em português (PPP-VP), foi aplicado a 39 gestantes como pré-teste, conforme o sugerido pela literatura e descrito no item 4.1.5.

Com a finalidade de corroborar a versão final em português obtida pelo comitê de especialistas em relação a sua equivalência semântica e cultural, e conseqüentemente sua validade de conteúdo e de face, foi aplicado a estas 39 gestantes um instrumento de avaliação qualitativa (APÊNDICE G), questionando-as sobre a compreensão do conteúdo dos itens, quais itens eram de difícil compreensão e qual a dificuldade em responder ao PPP-VP. Este instrumento contém apenas orientações para os coletadores sobre o quê deveria ser perguntado, sem haver padronização de perguntas.

As respostas obtidas estão no Quadro 2, em ordem decrescente de freqüência, que é citada entre parênteses ao final da mesma. As sentenças foram agrupadas conforme o conteúdo.

- A gestante não encontrou dificuldades para responder às questões. (13)
- A gestante não teve dificuldades, mas preferiu que o coletador fizesse a leitura do
instrumento e ela respondesse. (8)
- A gestante considerou fácil e resumido o questionário, abrangendo as questões do dia-a-
dia. (5)
- A gestante não compreendeu a questão F da seção de auto-estima da PPP. (3)
- Achou fácil, compreensão tranqüila. Atrapalhou-se com as perguntas da seção de auto-
estima. (3)
- Gestante afirma ter achado o questionário muito bom, porém sugere que a parte
'Avaliação do Apoio' poderia ser conjunta, a do companheiro e a de outras pessoas, para
facilitar o preenchimento da pesquisa. (2)
- Achou a escala de auto-estima confusa. Entendia as frases, mas na hora de marcar
atrapalhou-se, achou as frases E e H as de compreensão mais difícil. (1)
- Achou a frase H da seção de auto-estima de difícil compreensão. Foi difícil escolher uma
pessoa para considerar ao responder a seção de apoio de outros, pois toda a família mora
no interior. (1)

(CONTINUA) 
(CONTINUAÇÃO)

- Sugeriu trocar na parte do estresse para 'nenhum', 'pouco', 'médio', 'muito'. Do jeito que está é confuso. (1)

- Para a gestante, o questionário foi bem fácil de entender, não achou nada difícil nem confuso. As perguntas estavam claras e fáceis de responder. Gostou bastante de participar da pesquisa e espera ter ajudado. (1)

- Gestante auto-aplicou o questionário. No item "Perda recente de alguém especial" perguntou se poderia estar relacionado a um animal de estimação. Marcou estresse intenso devido à morte do cachorro. (1)

Quadro 2 - Apresentação da avaliação qualitativa do PPP- VP, durante o pré-teste. Porto Alegre, 2007

A compreensão do instrumento pelas gestantes ficou evidente, após o questionamento de seu entendimento, com 29 gestantes afirmando que acharam o instrumento fácil de ser respondido. Três gestantes citaram dificuldade em compreender o item $\mathrm{F}$ (Você tem uma atitude positiva consigo mesma), duas gestantes tiveram dificuldade com o item $\mathrm{H}$ (Você queria ter mais respeito por si mesma), e uma com o item $E$ (Você sente que não tem muito do que se orgulhar) todos da subescala de auto-estima. Entretanto, ao comparar estes itens com a versão obtida por Dini (2000) ao realizar a adaptação e validação da Escala de Autoestima de Rosenberg (na qual as autoras do PPP se basearam), verificamos que não há discrepâncias nas versões, conforme o Quadro 3.

\begin{tabular}{|c|c|}
\hline $\begin{array}{c}\text { Itens que as gestantes tiveram dúvida ao } \\
\text { responder }\end{array}$ & $\begin{array}{c}\text { Itens equivalentes da escala de Auto- } \\
\text { estima de Rosenberg* }\end{array}$ \\
\hline $\begin{array}{l}\text { E - Você sente que não tem muito do que se } \\
\text { orgulhar. }\end{array}$ & $\begin{array}{l}\text { E - (Não sinto satisfação nas coisas que } \\
\text { realizei.) Eu sinto que não tenho muito do que } \\
\text { me orgulhar. }\end{array}$ \\
\hline $\begin{array}{l}\mathrm{F} \text { - Você tem uma atitude positiva consigo } \\
\text { mesma. }\end{array}$ & $\begin{array}{l}\mathrm{F}-\text { Eu tenho uma atitude positiva } \\
\text { (pensamentos, atos, sentimentos positivos) } \\
\text { em relação a mim mesma. }\end{array}$ \\
\hline $\begin{array}{l}\mathrm{H}-\text { Você queria ter mais respeito por si } \\
\text { mesma. }\end{array}$ & $\begin{array}{l}\mathrm{H} \text { - (Não me dou o devido valor.) Gostaria de } \\
\text { ter mais respeito por mim mesma. }\end{array}$ \\
\hline
\end{tabular}

* As palavras que estão entre parênteses NÃO fazem parte da versão original do PPP.

Quadro 3 - Comparação entre itens da subescala de Auto-estima com os itens da Escala de Auto-estima de Rosenberg, versão adaptada por Dini (2000). 
Algumas respondentes, três no total, deram sugestões, como agregar as subescalas de apoio social e alterar as respostas possíveis na subescala de estresse. A primeira sugestão, feita por duas gestantes, de agregar as subescalas nos parece inviável, conforme o marco conceitual que embasa o instrumento. A segunda sugestão, feita por uma gestante, de alterar as respostas possíveis, pode ser levada em consideração, pois confere às respostas um tom coloquial, esperado através da equivalência idiomática.

Quando da aplicação do pré-teste às 39 gestantes, não obtivemos nãorespostas e o mesmo gerou resultados estatísticos suficientemente aproximados com os das autoras (CURRY; CAMPBELL; CHRISTIAN, 1994), apesar do valor do coeficiente alfa de Cronbach da subescala de estresse ter ficado abaixo de 0,70 que é valor preconizado pela literatura como aceitável. Nos estudos com diferentes amostras para a validação do PPP, Curry, Campbell e Christian (1994) e Curry, Burton e Fields (1998), o alfa de Cronbach oscilou entre 0,67 e 0,78. A Tabela 1 traz a comparação entre os valores encontrados no pré-teste e os encontrados pelas autoras.

Tabela 1 - Estatística descritiva e consistência interna das medidas obtidas pelo PPP em sua versão adaptada para o português e versão original: fase pré-teste

\begin{tabular}{lcccc}
\hline & \multicolumn{2}{c}{ Pré-teste $(\mathbf{n = 3 9 )}$} & \multicolumn{2}{c}{ Curry; Campbell; Christian, 1994 } \\
\cline { 2 - 5 } Subescala & Média (DP) & $\alpha$ de Cronbach & Média (DP) & $\alpha$ de Cronbach \\
\hline Estresse & $18,36(4,50)$ & 0,63 & $19,69(5,44)$ & 0,78 \\
Apoio comp. & $52,31(14,74)$ & 0,94 & $53,37(11,48)$ & 0,93 \\
Apoio outras & $51,08(15,02)$ & 0,94 & $50,33(13,33)$ & 0,95 \\
Auto-estima & $32,31(5,37)$ & 0,83 & $34,41(5,73)$ & 0,89 \\
\hline
\end{tabular}

* DP: desvio-padrão. 


\subsection{CARACTERIZAÇÃO DA AMOSTRA ESTUDADA}

A amostra estudada para a operacionalização da tradução, adaptação e validação do PPP para uso no Brasil foi de 241 gestantes que estiveram em consultas de pré-natal em Unidades Básicas de Saúde da Prefeitura Municipal de Porto Alegre, Rio Grande do Sul, no período de novembro de 2006 a junho de 2007. A caracterização dessa amostra, conforme idade, escolaridade, idade gestacional, número de gestações, número e tipos de partos, número de abortos e número de consultas de pré-natal, encontra-se na Tabela 2.

Entre essas 241 gestantes, $89(36,9 \%)$ eram primigestas, as demais multíparas com um máximo de oito filhos. $\mathrm{Na}$ amostra, 17 (7,1\%) gestantes não eram primigestas, porém não haviam parido por terem sofrido abortos prévios, com um total de 46 abortos entre todas as gestantes.

Tabela 2 - Distribuição das 241 gestantes do estudo conforme idade, escolaridade, idade gestacional, número de gestações, paridade, número de partos vaginais, de partos cesáreos, de abortos e número de consultas de pré-natal. Porto Alegre, 2007

\begin{tabular}{lccc}
\hline Variável & Média (DP) & Mediana & $\begin{array}{c}\text { Amplitude de } \\
\text { variação }\end{array}$ \\
\hline Idade (em anos) & $26,40(6,12)$ & 26 & $18-42$ \\
Escolaridade (em anos) & $9,34(2,50)$ & 11 & $1-16$ \\
Idade gestacional (em semanas) & $29,00(8,41)$ & 29 & $12-41$ \\
Número de gestações & $2,24(1,47)$ & 2 & $1-10$ \\
Paridade & $1,00(1,33)$ & 1 & $0-8$ \\
Número de partos vaginais & $1,87(1,19)$ & 1 & $1-8$ \\
Número de partos cesáreos & $1,19(0,55)$ & 1 & $1-3$ \\
Número de abortos & $0,36(0,58)$ & 0 & $0-2$ \\
Número de consultas de $\mathrm{PN}^{* *}$ & $5,00(2,82)$ & 5 & $1-18$ \\
\hline
\end{tabular}

* DP: desvio-padrão

${ }^{* *}$ PN: pré-natal 
A idade gestacional média foi de 29 semanas, e o número médio de consultas de pré-natal foi de cinco. A amplitude de variação das consultas de pré-natal foi entre uma e 18 consultas, $25(10,4 \%)$ gestantes estavam em sua primeira consulta de pré-natal, dado compatível com o fato de que 24 (10\%) das mulheres estavam entre 12 e 14 semanas de idade gestacional. Uma gestante fazia consultas concomitantemente na Unidade Básica de Saúde e em consultório particular, alcançando a marca de 18 consultas.

Dentre as 152 multíparas, apenas $17(7,1 \%)$ das gestantes não haviam realizado pré-natal nas gestações anteriores. A maioria das gestantes, 194 (80,3\%), não apresentava complicações na gestação atual, entretanto 112 (46,5\%) referiram estar tomando algum tipo de medicamento (como sulfato ferroso e outros polivitamínicos). O número total de partos vaginais anteriores foi de 100 (65,8\%), e o número total de cesarianas anteriores foi de 43 (28,3\%). Esse dado não foi informado por três participantes do estudo.

O peso médio das gestantes na data da coleta foi de $69,94 \mathrm{~kg}$, com aumento médio de $6,78 \mathrm{~kg}$ desde o início da gestação, compatível com a idade gestacional média de 29 semanas, conforme o Ministério da Saúde (BRASIL, 2006), ficando entre os percentis 25 e 50 . O valor médio da pressão arterial sistólica foi de 107,18 mmHg e da pressão diastólica de 66,12 mmHg. A diferença em relação ao início da gestação pode ser considerada biologicamente insignificante (menos de $5 \mathrm{mmHg}$, tanto para a pressão sistólica quanto para a diastólica). A altura uterina média, no dia da coleta de dados, foi de $27,18 \mathrm{~cm}$, compatível com a idade gestacional média da amostra (29 semanas).

Em relação à presença ou não de companheiro, $216(89,6 \%)$ gestantes da amostra possuem companheiro, não sendo questionado se eram casadas ou não e 
se coabitavam ou não. Vinte e seis $(10,8 \%)$ gestantes referiram não ter companheiro. A importância do dado está na aplicação da subescala de apoio social, que se divide em apoio recebido do companheiro e de outras pessoas.

\subsection{ESTATÍSTICA DESCRITIVA DO PPP-VP}

A análise dos resultados obtidos com a aplicação do PPP-VP em 241 gestantes é apresentada conforme as subescalas do instrumento: estresse, apoio social recebido do companheiro, apoio social recebido de outras pessoas e autoestima. Os valores mínimo e máximo possíveis de serem obtidos para a subescala de estresse são de 11 e 44, respectivamente. Para as subescalas de apoio social recebido do companheiro e de outras pessoas, o valor mínimo é de 11 e o máximo é de 66, para ambas. A subescala de auto-estima tem valor mínimo de 11 e valor máximo de 44. Como os itens $A, B, D, F, G$ e K estão redigidos de forma afirmativa, são computados com escore reverso, já que são sentenças que indicam maior autoestima quanto maior o valor, em contraposição às demais que estão na forma negativa. Maiores valores indicam maiores índices em todas as subescalas. A Tabela 3 apresenta as médias, desvios-padrão e intervalos de escores obtidos em cada subescala em comparação aos valores das autoras do PPP. 
Tabela 3 - Valores de médias, desvios-padrão e amplitude de variação dos escores encontrados no PPP-VP e por Curry; Campbell; Christian (1994)

\begin{tabular}{lcccc}
\hline & \multicolumn{2}{c}{ PPP (n=241) } & \multicolumn{2}{c}{ Curry; Campbell; Christian, 1994 } \\
\cline { 2 - 5 } Subescala & Média(DP)* & $\begin{array}{c}\text { Amplitude de } \\
\text { Variação }\end{array}$ & Média(DP) $^{*}$ & $\begin{array}{c}\text { Amplitude de } \\
\text { Variação }\end{array}$ \\
\hline Estresse & $18,84(5,01)$ & $11-37$ & $19,69(5,44)$ & $12-38$ \\
Apoio comp. & $53,49(14,06)$ & $11-66$ & $53,37(11,48)$ & $15-66$ \\
Apoio outras & $50,33(14,85)$ & $11-66$ & $50,33(13,33)$ & $11-66$ \\
Auto-estima & $32,54(5,07)$ & $14-44$ & $34,41(5,73)$ & $17-44$ \\
\hline
\end{tabular}

*DP: desvio-padrão

Ao tratar da validação e confiabilidade do PPP, Curry, Campbell e Christian (1994) não informam os valores de mediana, que, neste estudo, foram de 18 para a subescala de estresse, 59 para a subescala de apoio recebido do companheiro, 55 para apoio recebido de outras pessoas e a mediana para a subescala de autoestima foi de 33.

\subsubsection{Distribuição da freqüência de respostas para cada item de cada subescala do PPP}

A distribuição da freqüência de respostas para cada item de cada subescala do PPP encontra-se nas Tabelas 4, 5, 6 e 7.

Verifica-se na Tabela 4 que algumas gestantes não responderam a alguns itens, preferindo deixá-los em branco, o que é possível por ser o PPP auto-aplicável. Itens não respondidos aconteceram em todas as subescalas, diferentemente do que havia ocorrido no pré-teste, com maior freqüência na subescala de auto-estima, como será visto a seguir. 
Tabela 4 - Distribuição da freqüência das respostas das 241 gestantes aos itens da subescala de Estresse do PPP-VP. Porto Alegre, 2007

\begin{tabular}{|c|c|c|c|c|c|}
\hline Itens & $\begin{array}{c}\text { Nenhum } \\
(1)\end{array}$ & $\begin{array}{c}\text { Algum } \\
(2)\end{array}$ & $\begin{array}{c}\text { Moderado } \\
(3)\end{array}$ & $\begin{array}{c}\text { Intenso } \\
(4)\end{array}$ & $\begin{array}{c}\text { Em } \\
\text { branco }\end{array}$ \\
\hline $\begin{array}{l}\text { A. Preocupações financeiras } \\
\text { (por exemplo: alimentação, } \\
\text { moradia, saúde, transporte). }\end{array}$ & $64(26,6 \%)$ & $83(34,4 \%)$ & $59(24,5 \%)$ & $35(14,5 \%)$ & - \\
\hline $\begin{array}{l}\text { B. Outras preocupações com } \\
\text { dinheiro (por exemplo: } \\
\text { contas, etc.). }\end{array}$ & $48(19,9 \%)$ & $96(39,8 \%)$ & $56(23,2 \%)$ & $40(16,6 \%)$ & $1(0,4 \%)$ \\
\hline $\begin{array}{l}\text { C. Problemas relacionados à } \\
\text { família (companheiro, filhos, } \\
\text { etc.). }\end{array}$ & $109(45,2 \%)$ & $68(28,2 \%)$ & $34(14,1 \%)$ & $23(9,5 \%)$ & $7(2,9 \%)$ \\
\hline $\begin{array}{l}\text { D. Ter de mudar de } \\
\text { endereço, mesmo que tenha } \\
\text { sido recentemente ou que } \\
\text { acontecerá no futuro. }\end{array}$ & $144(59,8 \%)$ & $49(20,3 \%)$ & $31(12,9 \%)$ & $17(7,1 \%)$ & - \\
\hline $\begin{array}{l}\text { E. Perda recente de alguém } \\
\text { especial. }\end{array}$ & $174(72,2 \%)$ & $30(12,4 \%)$ & $13(5,4 \%)$ & $24(10 \%)$ & - \\
\hline F. Gestação atual. & $109(45,2 \%)$ & $64(26,6 \%)$ & $43(17,8 \%)$ & $18(7,5 \%)$ & $7(2,9 \%)$ \\
\hline $\begin{array}{l}\text { G. Estar sofrendo } \\
\text { violência/abuso: sexual, } \\
\text { emocional, ou física. }\end{array}$ & $217(90 \%)$ & $11(4,6 \%)$ & $6(2,5 \%)$ & $7(2,9 \%)$ & - \\
\hline $\begin{array}{l}\text { H. Problemas com álcool } \\
\text { e/ou drogas. }\end{array}$ & $207(85,9 \%)$ & $23(9,5 \%)$ & $4(1,7 \%)$ & $6(2,5 \%)$ & $1(0,4 \%)$ \\
\hline $\begin{array}{l}\text { I. Problemas no trabalho (por } \\
\text { exemplo: ter sido despedida, } \\
\text { etc.). }\end{array}$ & $175(72,6 \%)$ & $35(14,5 \%)$ & $15(6,2 \%)$ & $16(6,6 \%)$ & - \\
\hline $\begin{array}{l}\text { J. Problemas relacionados } \\
\text { aos amigos. }\end{array}$ & $183(75,9 \%)$ & $43(17,8 \%)$ & $7(2,9 \%)$ & $4(1,7 \%)$ & $4(1,7 \%)$ \\
\hline $\begin{array}{l}\text { K. Sentir-se geralmente } \\
\text { sobrecarregada. }\end{array}$ & $78(32,4 \%)$ & $61(25,3 \%)$ & $61(25,3 \%)$ & $40(16,6 \%)$ & $1(0,4 \%)$ \\
\hline
\end{tabular}

Os dados na Tabela 4 revelam que houve uma variabilidade de respostas das gestantes para os 11 itens da subescala de estresse, com uma tendência para as respostas 'nenhum' e 'algum', o que significa menores escores de estresse, cuja média total foi de 18,84 ( $\mathrm{DP}=5,01)$ entre as 241 gestantes (Tabela 3). Verifica-se, entretanto, que as preocupações financeiras existiam e são as que mais geraram estresse, de todas as situações citadas na subescala, conforme se constata através 
dos itens A, 'Preocupações financeiras', e B, 'Outras preocupações com dinheiro', aos quais apenas $64(26,6 \%)$ e $48(19,9 \%)$ das gestantes referiram não Ihes gerar nenhum estresse. São esperadas tais respostas, principalmente na atual conjuntura socioeconômica do nosso país. Os problemas relacionados à família, item C, causaram estresse para um pouco mais da metade das gestantes (125 - 51,8\%), destacando-se que para $68(28,2 \%)$ dessas mulheres, esse estresse é pequeno. Pode-se considerar neste item as preocupações que elas têm com os filhos em relação à educação, creche, alimentação, etc. No item E, 'Perda recente de alguém especial', $174(72,2 \%)$ das mulheres referiram não ter sofrido qualquer tipo de estresse por essa causa. As autoras do PPP também verificaram que menos de $30 \%$ das gestantes referiram qualquer estresse em relação à perda de alguém especial (CURRY; BURTON; FIELDS, 1998). Durante a avaliação qualitativa do PPP-VP, na coleta de pós-teste para verificação da estabilidade do instrumento, uma gestante referiu-se à perda do seu animal de estimação como causadora de estresse intenso, e outras duas gestantes referiram-se como perda ao fato de terem se separado de seus companheiros, o que para elas foi causador de estresse intenso. É preciso lembrar, ainda, que a perda por morte não é evento cotidiano das pessoas, mas na sua ocorrência, geralmente, é, para a família, grande gerador de estresse. A ampla maioria das mulheres, 207 (90\%), negou qualquer intensidade de estresse em conseqüência de sofrerem algum tipo de violência ou abuso, seja ele sexual, físico, ou emocional; bem como 207 (85,9\%) das mulheres negaram se sentir estressadas por problemas com álcool e/ou drogas. Acreditamos que ambas as questões ainda são constituídas de muitos tabus na sociedade e, ao ser vivenciado no interior da família, dificilmente estas são expostas, o que pode explicar a baixa pontuação destes itens na amostra estudada. Problemas no trabalho ou 
relacionados aos amigos, para a amostra (em torno de $75 \%$ das gestantes) parece não ser causa de estresse. Como não foi questionado se as gestantes estavam empregadas no momento da aplicação do instrumento, talvez possa ser esse motivo para aquela pontuação, caso muitas delas estivessem fora do mercado de trabalho formal. Apenas $78(32,4 \%)$ das gestantes não se sentiam sobrecarregadas à época da aplicação do PPP-VP. Tal fato é esperado durante a gestação, período no qual as mulheres sofrem mudanças em seus papéis sociais, de esposa, filha, trabalhadora, mãe ou futura mãe, com uma grande expectativa depositada sobre elas.

A Tabela 5, na página seguinte, traz a distribuição da freqüência das respostas aos itens da subescala de apoio social recebido do companheiro, sendo que 26 gestantes referiram não ter companheiro.

Os dados da Tabela 5 mostram que as respostas aos itens da subescala de apoio social recebido do companheiro estiveram distribuídas em todas as possibilidades, no entanto com direção para pontuação máxima, ou seja, revelando que o suporte do companheiro é percebido por grande parte das estudadas. $O$ item $\mathrm{H}$, 'Tolera meus altos e baixos e meus comportamentos inesperados' foi o que teve menor freqüência para a resposta 'muito satisfeita', ou seja, apenas 86 (40,0\%) das 215 gestantes que têm companheiro sentem que seus parceiros agem assim com elas. Altos e baixos no humor e no comportamento são esperados durante o período gestacional, marcadamente devido às alterações hormonais que lhe são inerentes. 
Tabela 5 - Distribuição da freqüência das respostas das 241 gestantes aos itens da subescala de Apoio do Companheiro do PPP-VP*. Porto Alegre, 2007

\begin{tabular}{|c|c|c|c|c|c|c|c|}
\hline Itens & 1 & 2 & 3 & 4 & 5 & 6 & $\begin{array}{l}\text { Não se } \\
\text { aplica }^{\#}\end{array}$ \\
\hline $\begin{array}{l}\text { A. Compartilha vivências } \\
\text { comigo. }\end{array}$ & $\begin{array}{c}10 \\
(4,7 \%)\end{array}$ & $\begin{array}{c}9 \\
(4,2 \%)\end{array}$ & $\begin{array}{c}13 \\
(6,0 \%)\end{array}$ & $\begin{array}{c}29 \\
(13,5 \%)\end{array}$ & $\begin{array}{c}48 \\
(22,3 \%)\end{array}$ & $\begin{array}{c}106 \\
(49,3 \%)\end{array}$ & 26 \\
\hline $\begin{array}{l}\text { B. Ajuda a manter meu } \\
\text { ânimo. }\end{array}$ & $\begin{array}{c}11 \\
(5,1 \%)\end{array}$ & $\begin{array}{c}11 \\
(5,1 \%)\end{array}$ & $\begin{array}{c}10 \\
(4,7 \%)\end{array}$ & $\begin{array}{c}39 \\
(18,1 \%)\end{array}$ & $\begin{array}{c}43 \\
(20,0 \%)\end{array}$ & $\begin{array}{c}101 \\
(47,0 \%)\end{array}$ & 26 \\
\hline $\begin{array}{l}\text { C. Me ajuda a sair de } \\
\text { situações difíceis. }\end{array}$ & $\begin{array}{c}12 \\
(5,6 \%)\end{array}$ & $\begin{array}{c}10 \\
(4,7 \%)\end{array}$ & $\begin{array}{c}10 \\
(4,7 \%)\end{array}$ & $\begin{array}{c}20 \\
(9,3 \%)\end{array}$ & $\begin{array}{c}47 \\
(21,9 \%)\end{array}$ & $\begin{array}{c}116 \\
(54,0 \%)\end{array}$ & 26 \\
\hline $\begin{array}{l}\text { D. Mostra interesse em } \\
\text { minhas atividades diárias e } \\
\text { problemas. }\end{array}$ & $\begin{array}{c}15 \\
(7,0 \%)\end{array}$ & $\begin{array}{c}7 \\
(3,3 \%)\end{array}$ & $\begin{array}{c}19 \\
(8,8 \%)\end{array}$ & $\begin{array}{c}19 \\
(8,8 \%)\end{array}$ & $\begin{array}{c}48 \\
(22,3 \%)\end{array}$ & $\begin{array}{c}107 \\
(49,8 \%)\end{array}$ & 26 \\
\hline $\begin{array}{l}\text { E. Sai de sua rotina para } \\
\text { fazer coisas especiais e } \\
\text { importantes para mim. }\end{array}$ & $\begin{array}{c}17 \\
(7,9 \%)\end{array}$ & $\begin{array}{c}6 \\
(2,8 \%)\end{array}$ & $\begin{array}{c}24 \\
(11,2 \%)\end{array}$ & $\begin{array}{c}30 \\
(14,0 \%)\end{array}$ & $\begin{array}{c}42 \\
(19,6 \%)\end{array}$ & $\begin{array}{c}95 \\
(44,4 \%)\end{array}$ & $27^{\#}$ \\
\hline $\begin{array}{l}\text { F. Me permite falar de } \\
\text { coisas que são bastante } \\
\text { pessoais e particulares. }\end{array}$ & $\begin{array}{c}17 \\
(7,9 \%)\end{array}$ & $\begin{array}{c}10 \\
(4,7 \%)\end{array}$ & $\begin{array}{c}18 \\
(8,4 \%)\end{array}$ & $\begin{array}{c}27 \\
(12,6 \%)\end{array}$ & $\begin{array}{c}18 \\
(8,4 \%)\end{array}$ & $\begin{array}{c}125 \\
(58,1 \%)\end{array}$ & 26 \\
\hline $\begin{array}{l}\text { G. Demonstra para mim } \\
\text { que valoriza o que eu faço } \\
\text { para ele. }\end{array}$ & $\begin{array}{c}17 \\
(7,9 \%)\end{array}$ & $\begin{array}{c}8 \\
(3,7 \%)\end{array}$ & $\begin{array}{c}15 \\
(7,0 \%)\end{array}$ & $\begin{array}{c}21 \\
(9,8 \%)\end{array}$ & $\begin{array}{c}46 \\
(21,4 \%)\end{array}$ & $\begin{array}{c}108 \\
(50,2 \%)\end{array}$ & 26 \\
\hline $\begin{array}{l}\text { H. Tolera meus "altos e } \\
\text { baixos" e meus } \\
\text { comportamentos } \\
\text { inesperados. }\end{array}$ & $\begin{array}{c}17 \\
(7,9 \%)\end{array}$ & $\begin{array}{c}11 \\
(5,1 \%)\end{array}$ & $\begin{array}{c}22 \\
(10,2 \%)\end{array}$ & $\begin{array}{c}30 \\
(14,0 \%)\end{array}$ & $\begin{array}{c}49 \\
(22,8 \%)\end{array}$ & $\begin{array}{c}86 \\
(40,0 \%)\end{array}$ & 26 \\
\hline $\begin{array}{l}\text { I. Me leva a sério quando } \\
\text { eu tenho preocupações. }\end{array}$ & $\begin{array}{c}12 \\
(5,6 \%)\end{array}$ & $\begin{array}{c}12 \\
(5,6 \%)\end{array}$ & $\begin{array}{c}10 \\
(4,7 \%)\end{array}$ & $\begin{array}{c}21 \\
(9,8 \%)\end{array}$ & $\begin{array}{c}38 \\
(17,7 \%)\end{array}$ & $\begin{array}{c}122 \\
(56,7 \%)\end{array}$ & 26 \\
\hline $\begin{array}{l}\text { J. Me diz coisas que } \\
\text { tornam minha situação } \\
\text { mais clara e fácil de ser } \\
\text { compreendida. }\end{array}$ & $\begin{array}{c}18 \\
(8,4 \%)\end{array}$ & $\begin{array}{c}7 \\
(3,3 \%)\end{array}$ & $\begin{array}{c}19 \\
(8,8 \%)\end{array}$ & $\begin{array}{c}27 \\
(12,6 \%)\end{array}$ & $\begin{array}{c}46 \\
(21,4 \%)\end{array}$ & $\begin{array}{c}98 \\
(45,6 \%)\end{array}$ & 26 \\
\hline $\begin{array}{l}\text { K. Deixa claro que ele } \\
\text { estará por perto se eu } \\
\text { precisar }\end{array}$ & $\begin{array}{c}12 \\
(5,6 \%)\end{array}$ & $\begin{array}{c}6 \\
(2,8 \%)\end{array}$ & $\begin{array}{c}8 \\
(3,7 \%)\end{array}$ & $\begin{array}{c}15 \\
(7,0 \%)\end{array}$ & $\begin{array}{c}21 \\
(9,8 \%)\end{array}$ & $\begin{array}{c}153 \\
(71,2 \%)\end{array}$ & 26 \\
\hline
\end{tabular}

* Os escores são de 1 a 6 , com 1 correspondendo à "Muito Insatisfeita" e 6 correspondendo à "Muito satisfeita".

\# Corresponde ao número total de gestantes que não têm companheiro.

* Uma gestante deixou este item em branco $(0,46 \%)$.

$\mathrm{O}$ item $\mathrm{H}$, já citado, o item E, 'Sai de sua rotina para fazer coisas especiais e importantes para mim', e o item J, 'Me diz coisas que tornam minha situação mais clara e fácil de ser compreendida' são os únicos que não atingiram um mínimo de 
$80 \%$ das respostas com valores acima de quatro, que seriam indicativos de percepção positiva das gestantes com o apoio social recebido de seus companheiros. É preciso considerar que sair da rotina possa ser difícil para os parceiros destas mulheres, especialmente se estas gestantes esperam que os companheiros abandonem seu ambiente de trabalho para acompanhá-las nas consultas ou exames de pré-natal, por exemplo, o que é praticamente impossível frente à realidade econômica e à possibilidade de perda de emprego. A verbalização do apoio através de palavras de compreensão e estímulo durante a gravidez não são claramente percebidas pelas gestantes que se ressentem de seus companheiros não terem habilidade para se expressarem com elas. Entretanto, 189 (88\%) das gestantes reconhecem a presença do companheiro em situações de necessidade, respondendo com valores acima de quatro para o item K, 'Deixa claro que estará por perto se eu precisar'. Assim, mesmo que se sintam insatisfeitas com o apoio do parceiro, sabem que podem contar com eles nas adversidades.

A Tabela 6 mostra que em relação ao apoio que as gestantes percebem receber de outras pessoas, as respostas também se distribuíram em todas as respostas possíveis, porém com tendência à satisfação. Ao comparar os valores da Tabela 6 com os valores da Tabela 5, verifica-se que os índices de satisfação com o apoio recebido de outras pessoas (com escores acima de quatro) são menores em relação ao apoio recebido do companheiro. Na Tabela 6, apenas nos itens A, 'Compartilha vivências comigo', e K, 'Deixa claro que ele/ela estará por perto se eu precisar', mais de $80 \%$ das gestantes manifestaram-se com respostas acima de quatro. Nos demais nove itens, em torno de $75 \%$ das gestantes percebem o apoio de outras pessoas como satisfatório. 
Tabela 6 - Distribuição da freqüência das respostas das 241 gestantes aos itens da subescala de Apoio de Outras Pessoas do PPP-VP*. Porto Alegre, 2007

\begin{tabular}{|c|c|c|c|c|c|c|c|}
\hline Itens & 1 & 2 & 3 & 4 & 5 & 6 & $\begin{array}{l}\text { Não se } \\
\text { aplica }\end{array}$ \\
\hline $\begin{array}{l}\text { A. Compartilha vivências } \\
\text { comigo. }\end{array}$ & $\begin{array}{c}17 \\
(7,1 \%)\end{array}$ & $\begin{array}{c}9 \\
(3,8 \%)\end{array}$ & $\begin{array}{c}18 \\
(7,5 \%)\end{array}$ & $\begin{array}{c}41 \\
(17,1 \%)\end{array}$ & $\begin{array}{c}52 \\
(21,7 \%)\end{array}$ & $\begin{array}{c}103 \\
(42,9 \%)\end{array}$ & 1 \\
\hline $\begin{array}{l}\text { B. Ajuda a manter meu } \\
\text { ânimo. }\end{array}$ & $\begin{array}{c}16 \\
(6,7 \%)\end{array}$ & $\begin{array}{c}12 \\
(5 \%)\end{array}$ & $\begin{array}{c}23 \\
(9,6 \%)\end{array}$ & $\begin{array}{c}30 \\
(12,6 \%)\end{array}$ & $\begin{array}{c}54 \\
(22,6 \%)\end{array}$ & $\begin{array}{c}104 \\
(43,5 \%)\end{array}$ & $2^{\#}$ \\
\hline $\begin{array}{l}\text { C. Me ajuda a sair de } \\
\text { situações difíceis. }\end{array}$ & $\begin{array}{c}17 \\
(7,1 \%)\end{array}$ & $\begin{array}{c}11 \\
(4,6 \%)\end{array}$ & $\begin{array}{c}31 \\
(13,0 \%)\end{array}$ & $\begin{array}{c}26 \\
(10,9 \%)\end{array}$ & $\begin{array}{c}47 \\
(19,7 \%)\end{array}$ & $\begin{array}{c}106 \\
(44,5 \%)\end{array}$ & $3^{\Delta}$ \\
\hline $\begin{array}{l}\text { D. Mostra interesse em } \\
\text { minhas atividades diárias e } \\
\text { problemas. }\end{array}$ & $\begin{array}{c}15 \\
(6,3 \%)\end{array}$ & $\begin{array}{c}20 \\
(8,3 \%)\end{array}$ & $\begin{array}{c}32 \\
(13,3 \%)\end{array}$ & $\begin{array}{c}33 \\
(13,8 \%)\end{array}$ & $\begin{array}{c}47 \\
(19,6 \%)\end{array}$ & $\begin{array}{c}93 \\
(38,8 \%)\end{array}$ & 1 \\
\hline $\begin{array}{l}\text { E. Sai de sua rotina para } \\
\text { fazer coisas especiais e } \\
\text { importantes para mim. }\end{array}$ & $\begin{array}{c}26 \\
(10,8 \%)\end{array}$ & $\begin{array}{c}23 \\
(9,6 \%)\end{array}$ & $\begin{array}{c}27 \\
(11,3 \%)\end{array}$ & $\begin{array}{c}38 \\
(15,8 \%)\end{array}$ & $\begin{array}{c}53 \\
(22,1 \%)\end{array}$ & $\begin{array}{c}73 \\
(30,4 \%)\end{array}$ & 1 \\
\hline $\begin{array}{l}\text { F. Me permite falar de } \\
\text { coisas que são bastante } \\
\text { pessoais e particulares. }\end{array}$ & $\begin{array}{c}23 \\
(9,6 \%)\end{array}$ & $\begin{array}{c}19 \\
(7,9 \%)\end{array}$ & $\begin{array}{c}18 \\
(7,5 \%)\end{array}$ & $\begin{array}{c}28 \\
(11,7 \%)\end{array}$ & $\begin{array}{c}43 \\
(17,9 \%)\end{array}$ & $\begin{array}{c}109 \\
(45,4 \%)\end{array}$ & 1 \\
\hline $\begin{array}{l}\text { G. Demonstra para mim } \\
\text { que valoriza o que eu faço } \\
\text { para ele/ela. }\end{array}$ & $\begin{array}{c}23 \\
(9,6 \%)\end{array}$ & $\begin{array}{c}14 \\
(5,8 \%)\end{array}$ & $\begin{array}{c}24 \\
(10,0 \%)\end{array}$ & $\begin{array}{c}41 \\
(17,1 \%)\end{array}$ & $\begin{array}{c}45 \\
(18,8 \%)\end{array}$ & $\begin{array}{c}93 \\
(38,8 \%)\end{array}$ & 1 \\
\hline $\begin{array}{l}\text { H. Tolera meus "altos e } \\
\text { baixos" e meus } \\
\text { comportamentos } \\
\text { inesperados. }\end{array}$ & $\begin{array}{c}18 \\
(7,5 \%)\end{array}$ & $\begin{array}{c}18 \\
(7,5 \%)\end{array}$ & $\begin{array}{c}29 \\
(12,1 \%)\end{array}$ & $\begin{array}{c}37 \\
(15,5 \%)\end{array}$ & $\begin{array}{c}65 \\
(27,2 \%)\end{array}$ & $\begin{array}{c}72 \\
(30,1 \%)\end{array}$ & $2^{\#}$ \\
\hline $\begin{array}{l}\text { I. Me leva a sério quando } \\
\text { eu tenho preocupações. }\end{array}$ & $\begin{array}{c}18 \\
(7,5 \%)\end{array}$ & $\begin{array}{c}11 \\
(4,6 \%)\end{array}$ & $\begin{array}{c}27 \\
(11,3 \%)\end{array}$ & $\begin{array}{c}27 \\
(11,3 \%)\end{array}$ & $\begin{array}{c}43 \\
(17,9 \%)\end{array}$ & $\begin{array}{c}114 \\
(47,5 \%)\end{array}$ & 1 \\
\hline $\begin{array}{l}\text { J. Me diz coisas que } \\
\text { tornam minha situação } \\
\text { mais clara e fácil de ser } \\
\text { compreendida. }\end{array}$ & $\begin{array}{c}17 \\
(7,1 \%)\end{array}$ & $\begin{array}{c}19 \\
(7,9 \%)\end{array}$ & $\begin{array}{c}20 \\
(8,3 \%)\end{array}$ & $\begin{array}{c}31 \\
(12,9 \%)\end{array}$ & $\begin{array}{c}54 \\
(22,5 \%)\end{array}$ & $\begin{array}{c}99 \\
(41,3 \%)\end{array}$ & 1 \\
\hline $\begin{array}{l}\text { K. Deixa claro que ele/ela } \\
\text { estará por perto se eu } \\
\text { precisar }\end{array}$ & $\begin{array}{c}19 \\
(7,9 \%)\end{array}$ & $\begin{array}{c}9 \\
(3,8 \%)\end{array}$ & $\begin{array}{c}10 \\
(4,2 \%)\end{array}$ & $\begin{array}{c}21 \\
(8,8 \%)\end{array}$ & $\begin{array}{c}39 \\
(16,3 \%)\end{array}$ & $\begin{array}{c}142 \\
(59,2 \%)\end{array}$ & 1 \\
\hline
\end{tabular}

* Os escores são de 1 a 6, com 1 correspondendo à "Muito Insatisfeita" e 6 correspondendo à "Muito satisfeita".

\#Uma gestante não respondeu a este item $(0,42 \%)$.

${ }^{\Delta}$ Duas gestantes não responderam a este item $(0,83 \%)$.

O item com menor escore de satisfação foi o item E, 'Sai de sua rotina para fazer coisas especiais e importantes para mim', o que sugere que também os familiares e outras pessoas importantes para a gestante têm dificuldades de 
participar de atividades que ela considera importantes. Igualmente à subescala de apoio do companheiro, o item com maior escore de satisfação é o K, 'Deixa claro que estará por perto se eu precisar', que dá às gestantes a confiança de que não estarão sozinhas em situações difíceis.

Tabela 7 - Distribuição da freqüência das respostas das 241 gestantes aos itens da subescala de Auto-estima do PPP-VP. Porto Alegre, 2007

\begin{tabular}{|c|c|c|c|c|c|}
\hline Itens & $\begin{array}{l}\text { Concordo } \\
\text { complet. } \\
\text { (1) }\end{array}$ & $\begin{array}{c}\text { Concordo } \\
\text { (2) }\end{array}$ & $\begin{array}{c}\text { Discordo } \\
(3) \\
\end{array}$ & $\begin{array}{l}\text { Discordo } \\
\text { complet. } \\
(4)\end{array}$ & $\begin{array}{c}\text { Em } \\
\text { branco }\end{array}$ \\
\hline $\begin{array}{l}\text { A. Você sente que é uma } \\
\text { pessoa de valor, ou pelo } \\
\text { menos que é igual aos } \\
\text { outros. }\end{array}$ & $105(43,6 \%)$ & $115(47,7 \%)$ & $18(7,5 \%)$ & $3(1,2 \%)$ & - \\
\hline $\begin{array}{l}\text { B. Você sente que tem um } \\
\text { grande número de } \\
\text { qualidades. }\end{array}$ & $75(31,4 \%)$ & $143(59,8 \%)$ & $17(7,1 \%)$ & $4(1,7 \%)$ & $2(0,8 \%)$ \\
\hline $\begin{array}{l}\text { C. No final das contas, você } \\
\text { sente que é um fracasso. }\end{array}$ & $11(4,6 \%)$ & $20(8,4 \%)$ & $116(48,9 \%)$ & $90(38,0 \%)$ & $4(1,7 \%)$ \\
\hline $\begin{array}{l}\text { D. Você se sente capaz de } \\
\text { fazer as coisas pelo menos } \\
\text { tão bem quanto a maioria } \\
\text { das pessoas. }\end{array}$ & $87(36,3 \%)$ & $120(50,0 \%)$ & $27(11,3 \%)$ & $6(2,5 \%)$ & $1(0,4 \%)$ \\
\hline $\begin{array}{l}\text { E. Você sente que não tem } \\
\text { muito do que se orgulhar. }\end{array}$ & $15(6,3 \%)$ & $4920,4 \%)$ & $106(44,2 \%)$ & $70(29,2 \%)$ & $1(0,4 \%)$ \\
\hline $\begin{array}{l}\text { F. Você tem uma atitude } \\
\text { positiva consigo mesma. }\end{array}$ & $83(35,6 \%)$ & $122(52,4 \%)$ & $21(9,0 \%)$ & $7(3,0 \%)$ & $8(3,3 \%)$ \\
\hline $\begin{array}{l}\text { G. De modo geral, você se } \\
\text { sente satisfeita consigo } \\
\text { mesma. }\end{array}$ & $75(31,5 \%)$ & $125(52,5 \%)$ & $30(12,6 \%)$ & $8(3,4 \%)$ & $3(1,2 \%)$ \\
\hline $\begin{array}{l}\text { H. Você queria ter mais } \\
\text { respeito por si mesma. }\end{array}$ & $36(15,3 \%)$ & $83(35,2 \%)$ & $80(33,9 \%)$ & $37(15,7 \%)$ & $5(2,1 \%)$ \\
\hline $\begin{array}{l}\text { I. Às vezes, você se sente } \\
\text { inútil. }\end{array}$ & $19(8,0 \%)$ & $93(39,1 \%)$ & $79(33,2 \%)$ & $47(19,7 \%)$ & $3(1,2 \%)$ \\
\hline $\begin{array}{l}\text { J. Às vezes, você acha que } \\
\text { não é boa que chega. }\end{array}$ & $16(6,7 \%)$ & $105(43,8 \%)$ & $86(35,8 \%)$ & $33(13,8 \%)$ & $1(0,4 \%)$ \\
\hline $\begin{array}{l}\text { K. Você acha que controla } \\
\text { a sua vida. }\end{array}$ & $59(24,5 \%)$ & $121(50,2 \%)$ & $48(19,9 \%)$ & $13(5,4 \%)$ & - \\
\hline
\end{tabular}


A Tabela 7 mostra a freqüência das respostas à subescala de auto-estima. As respostas tiveram tendência a escores que indicam maiores índices de auto-estima, porém percebe-se claramente a grande freqüência de respostas em branco, com exceção de apenas dois itens (A e K). Ao enviar material com orientações sobre o preenchimento do PPP, a autora principal, Mary Ann Curry, informou que o grande número de frases redigidas de forma negativa poderia confundir as respondentes, porém são assim redigidas propositadamente. Entretanto, o item com maior número de respostas em branco é o F, 'Você tem uma atitude positiva consigo mesma', frase redigida de forma afirmativa, mas que pode ter confundido estas oito gestantes por não ser expressão coloquial. O item com maior freqüência de respostas de concordância é o A, 'Você sente que é uma pessoa de valor, ou pelo menos que é igual aos outros', com $220(91,3 \%)$ das gestantes concordando parcial ou completamente. Observa-se que o item com respostas mais divididas é o H, 'Você queria ter mais respeito por si mesma', em que 119 (50,5\%) gestantes concordaram, parcial ou completamente, e 117 (49,5\%) discordaram, parcial ou completamente.

\subsection{AVALIAÇÃO DAS PROPRIEDADES PSICOMÉTRICAS DO PPP-VP}

\subsubsection{Confiabilidade}

A confiabilidade do PPP-VP foi verificada através da avaliação da estabilidade e da consistência interna.

\subsubsection{ESTABILIDADE}

A verificação da estabilidade foi realizada por meio da testagem da reprodutibilidade, com o instrumento sendo reaplicado em até sete dias, e foi chamado de reteste. 
Através do Teste $\mathrm{t}$ para amostras pareadas, verificou-se que o PPP-VP mantém os escores obtidos após um pequeno intervalo de tempo, pois não houve diferença estatisticamente significativa entre as médias do teste e reteste, ou seja, o PPP-VP comportou-se como se queria, pois reproduziu resultados semelhantes aos da coleta inicial. O PPP-VP foi reaplicado em 27 gestantes, com intervalo máximo de sete dias entre as duas coletas. Os valores das médias, desvios-padrão e valor-p para o teste e o reteste encontram-se na Tabela 8.

Tabela 8 - Médias, desvios-padrão e valores de $p$ do teste e reteste do PPP-VP. Porto Alegre, 2007

\begin{tabular}{lccc}
\hline Subescala & $\begin{array}{c}\text { Teste }(\mathbf{n}=27) \\
\text { Média (DP)* }\end{array}$ & $\begin{array}{c}\text { Reteste }(\mathbf{n}=27) \\
\text { Média }(\mathbf{D P})^{*}\end{array}$ & $\boldsymbol{p}$ \\
\hline Estresse & $19,11(4,41)$ & $18,19(5,17)$ & 0,150 \\
Apoio comp. & $54,58(15,07)$ & $54,25(15,34)$ & 0,685 \\
Apoio outras & $53,85(15,58)$ & $54,08(14,90)$ & 0,807 \\
Auto-estima & $33,85(4,27)$ & $32,85(4,87)$ & 0,102 \\
\hline
\end{tabular}

*DP: desvio-padrão

As autoras do PPP, ao procurarem verificar esta propriedade, não observaram um intervalo mínimo ou máximo de tempo, havendo amplitude de seis a 56 dias entre uma coleta e outra. Mesmo assim, encontraram uma estabilidade moderada ao longo do tempo, com valores de $p$ variando entre 0,78 e 0,84.

\subsubsection{CONSISTÊNCIA INTERNA}

A consistência interna de cada subescala do instrumento de coleta de dados do PPP-VP foi verificada através do coeficiente de alfa de Cronbach, e está apresentada na Tabela 9. 
Tabela 9 - Valores de alfa de Cronbach das subescalas do PPP-VP ( $n=241)$. Porto Alegre, 2007

\begin{tabular}{lcc}
\hline Subescala & Alfa de Cronbach & $\begin{array}{c}\text { Alfa de Cronbach se } \\
\text { item excluído* }\end{array}$ \\
\hline Estresse & 0,7133 & 0,7334 \\
Apoio companheiro & 0,9588 & 0,9588 \\
Apoio outras & 0,9591 & 0,9591 \\
Auto-estima & 0,7912 & 0,7982 \\
\hline
\end{tabular}

"Estresse: "Perda recente de alguém especial"

Auto-estima: "Você queria ter mais respeito por si mesma"

Como visto acima, os valores do coeficiente de alfa de Cronbach para todas as subescalas do PPP-VP são superiores a 0,70 que é o valor preconizado na literatura como aceitável. A seguir, são apresentadas as tabelas de cada subescala, com os valores do coeficiente de alfa de Cronbach que seriam obtidos se cada um desses itens fosse excluído.

Na Tabela 10, que traz a subescala de estresse, verifica-se que se o item $E$, 'Perda recente de alguém especial', fosse excluído, obteríamos o maior valor possível do coeficiente de alfa de Cronbach, que aumentaria para 0,7334. Este item não gerou dúvidas na avaliação semântica realizada juntamente com o pré-teste (Quadros 2 e 3), e também não foi um item que teve respostas em branco (Tabela 4) ao preenchimento do PPP. Novamente, sugere-se que esse não foi um evento do cotidiano das gestantes da amostra estudada. 
Tabela 10 - Valores dos coeficientes de alfa de Cronbach quando cada um dos itens da subescala de Estresse é excluído.

Porto Alegre, 2007

\begin{tabular}{|c|c|}
\hline Itens & $\begin{array}{c}\text { Alfa de Cronbach se o } \\
\text { item for excluído }\end{array}$ \\
\hline \multicolumn{2}{|l|}{ Total da subescala $\alpha=0,7133$} \\
\hline $\begin{array}{l}\text { A. Preocupações financeiras (por exemplo: } \\
\text { alimentação, moradia, saúde, transporte). }\end{array}$ & 0,6718 \\
\hline $\begin{array}{l}\text { B. Outras preocupações com dinheiro (por exemplo: } \\
\text { contas, etc). }\end{array}$ & 0,6691 \\
\hline $\begin{array}{l}\text { C. Problemas relacionados à família (companheiro, } \\
\text { filhos, etc.). }\end{array}$ & 0,6737 \\
\hline $\begin{array}{l}\text { D. Ter de mudar de endereço, mesmo que tenha sido } \\
\text { recentemente ou que acontecerá no futuro. }\end{array}$ & 0,6977 \\
\hline E. Perda recente de alguém especial. & 0,7334 \\
\hline F. Gestação atual. & 0,6811 \\
\hline $\begin{array}{l}\text { G. Estar sofrendo violência/abuso: sexual, emocional, } \\
\text { ou física. }\end{array}$ & 0,6968 \\
\hline H. Problemas com álcool e/ou drogas. & 0,7050 \\
\hline $\begin{array}{l}\text { I. Problemas no trabalho (por exemplo: ter sido } \\
\text { despedida, etc.). }\end{array}$ & 0,7047 \\
\hline J. Problemas relacionados aos amigos. & 0,6987 \\
\hline K. Sentir-se geralmente sobrecarregada. & 0,6848 \\
\hline
\end{tabular}

Nas Tabelas 11 e 12, vemos que os valores dos coeficientes de alfa de Cronbach das subescalas de apoio social recebido do companheiro e do apoio social recebido de outras pessoas são elevados e que não seriam alterados se algum item fosse excluído de qualquer uma das subescalas. Ou seja, as subescalas de apoio social são consideradas consistentes, com seus itens medindo as mesmas características e conferindo homogeneidade na mensuração de cada dimensão. 
Tabela 11 - Valores dos coeficientes de alfa de Cronbach quando cada um dos itens da subescala de Apoio do Companheiro é excluído. Porto Alegre, 2007

Total da subescala $\alpha=0,9588$

A. Compartilha vivências comigo.

0,9548

B. Ajuda manter meu ânimo.

0,9540

C. Me ajuda a sair de situações difíceis.

0,9544

D. Mostra interesse em minhas atividades diárias e 0,9545 problemas.

0,9578

E. Sai de sua rotina para fazer coisas especiais e importantes para mim.

F. Me permite falar de coisas que são bastante pessoais e particulares.

G. Demonstra para mim que valoriza o que eu faço para ele/ela.

H. Tolera meus "altos e baixos" e meus comportamentos inesperados.

0,9560

I. Me leva a sério quando eu tenho preocupações.

J. Me diz coisas que tornam minha situação mais clara e fácil de ser compreendida.

K. Deixa claro que ele/ela estará por perto se eu precisar. 
Tabela 12 - Valores dos coeficientes de alfa de Cronbach quando cada um dos itens da subescala de apoio de Outras Pessoas é excluído. Porto Alegre, 2007

\begin{tabular}{lc}
\hline \multicolumn{1}{c}{ Itens } & $\begin{array}{c}\text { Alfa de Cronbach se o } \\
\text { item for excluído }\end{array}$ \\
\hline Total da subescala $\alpha=0,9591$ & 0,9554 \\
$\begin{array}{l}\text { A. Compartilha vivências comigo. } \\
\text { B. Ajuda manter meu ânimo. }\end{array}$ & 0,9541 \\
$\begin{array}{l}\text { C. Me ajuda a sair de situações difíceis. } \\
\text { D. Mostra interesse em minhas atividades diárias e } \\
\text { problemas. }\end{array}$ & 0,9552 \\
$\begin{array}{l}\text { E. Sai de sua rotina para fazer coisas especiais e } \\
\text { importantes para mim. }\end{array}$ & 0,9536 \\
$\begin{array}{l}\text { F. Me permite falar de coisas que são bastante } \\
\text { pessoais e particulares. }\end{array}$ & 0,9573 \\
$\begin{array}{l}\text { G. Demonstra para mim que valoriza o que eu faço } \\
\text { para ele/ela. }\end{array}$ & 0,9562 \\
$\begin{array}{l}\text { H. Tolera meus "altos e baixos" e meus } \\
\text { comportamentos inesperados. }\end{array}$ & 0,9544 \\
I. Me leva a sério quando eu tenho preocupações. & 0,9573 \\
$\begin{array}{l}\text { J. Me diz coisas que tornam minha situação mais } \\
\text { clara e fácil de ser compreendida. }\end{array}$ & 0,9541 \\
K. Deixa claro que ele/ela estará por perto se eu \\
precisar.
\end{tabular}

A Tabela 13 mostra os valores dos coeficientes de alfa de Cronbach que seriam obtidos se cada um desses itens fosse excluído. $\mathrm{O}$ item $\mathrm{H}$, 'Você queria ter mais respeito por si mesma', é o único item que, ao ser excluído, aumentaria o valor do coeficiente de alfa de Cronbach, de 0,7912 para 0,7982. Entretanto, essa elevação, por ser mínima, não justificaria a exclusão desse item. 
Tabela 13 - Valores dos coeficientes de alfa de Cronbach quando cada um dos itens da subescala de Auto-estima é excluído. Porto Alegre, 2007

\begin{tabular}{lc}
\hline \multicolumn{1}{c}{ Itens } & $\begin{array}{c}\text { Alfa de Cronbach se o } \\
\text { item for excluído }\end{array}$ \\
\hline $\begin{array}{l}\text { Total da subescala } \\
\alpha=0,7912\end{array}$ & 0,7808 \\
$\begin{array}{l}\text { A. Você sente que é uma pessoa de valor, ou pelo } \\
\text { menos que é igual aos outros. }\end{array}$ & 0,7789 \\
$\begin{array}{l}\text { B. Você sente que tem um grande número de } \\
\text { qualidades. }\end{array}$ & 0,7640 \\
C. No final das contas, você sente que é um fracasso. & 0,7797 \\
$\begin{array}{l}\text { D. Você se sente capaz de fazer as coisas pelo } \\
\text { menos tão bem quanto a maioria das pessoas. }\end{array}$ & 0,7767 \\
E. Você sente que não tem muito do que se orgulhar. & 0,7629 \\
F. Você tem uma atitude positiva consigo mesma. & 0,7603 \\
G. De modo geral, você se sente satisfeita consigo & \\
mesma. & 0,7982 \\
H. Você queria ter mais respeito por si mesma. & 0,7637 \\
I. Às vezes, você se sente inútil. & 0,7640 \\
J. Às vezes, você acha que não é boa que chega. & 0,7920 \\
K. Você acha que controla a sua vida. & \\
\hline
\end{tabular}

\subsubsection{Responsividade}

A responsividade do PPP-VP foi verificada através do Teste t para amostras pareadas, e constatou-se que o PPP-VP não apresentou tal propriedade, conforme visualizado na Tabela 14, pois não houve diferença estatisticamente significativa entre as médias do teste e pós-teste. A idade gestacional média das respondentes à época do primeiro preenchimento do instrumento na Unidade Básica de Saúde era de 15,24 ( $\mathrm{DP}=3,07)$ semanas, enquanto à aplicação do pós-teste, através de contato telefônico, a idade gestacional média era de 34,69 ( $\mathrm{DP}=2,87)$ semanas de gestação. 
Infelizmente, com intervalo maior entre as aplicações do instrumento, o PPP-VP não detectou mudanças nas gestantes em relação aos construtos, o que seria esperado e é inclusive descrito na literatura. As variações dos níveis de estresse, principalmente, são flutuantes ao longo da gestação, com diferenças marcantes sendo descritas entre o primeiro e o terceiro trimestre, entretanto, todas as gestantes desta amostra encontravam-se no segundo ou terceiro semestre de gestação.

Tabela 14 - Médias, desvios-padrão e valores de $p$ do teste e pós-teste do PPP-VP. Porto Alegre, 2007

\begin{tabular}{lccc}
\hline Subescala & $\begin{array}{c}\text { Teste }(\mathbf{n}=29) \\
\text { Média (DP)* }\end{array}$ & $\begin{array}{c}\text { Pós-teste }(\mathbf{n}=29) \\
\text { Média (DP)* }\end{array}$ & $\boldsymbol{p}$ \\
\hline Estresse & $18,58(5,53)$ & $18,93(4,44)$ & 0,587 \\
Apoio comp. & $53,52(12,13)$ & $55,33(10,71)$ & 0,225 \\
Apoio outras & $50,00(14,65)$ & $53,18(10,76)$ & 0,097 \\
Auto-estima & $31,59(5,39)$ & $32,76(3,83)$ & 0,158 \\
\hline
\end{tabular}

*DP: desvio-padrão

Pode-se considerar que um dos fatores de limitação para a verificação da responsividade do PPP-VP seja o tamanho reduzido da amostra (29 gestantes). Além disso, a coleta secundária foi realizada por telefone, o que pode ter gerado distanciamento entre coletadora e gestante; dúvidas por não estar visualizando o instrumento; e necessidade de algumas vezes a coletadora confirmar qual a resposta escolhida (por exemplo, na subescala de auto-estima, quando a gestante respondia a algum item com frase 'ah, eu acho que sim', era necessário que a coletadora perguntasse: 'concorda completamente ou só concorda', o que gerava uma resposta não espontânea). 


\subsubsection{Validade}

A validade de um instrumento pode ser verificada, inicialmente, pela análise fatorial, além de testes específicos para comprovar sua validade de construto e critério.

Analisou-se a independência das subescalas, e verificou-se que todos os itens das subescalas de apoio social agruparam-se nos mesmos fatores, enquanto os itens das subescalas de estresse e auto-estima dividiram-se em outros fatores, porém não se dividiram em fatores de outras subescalas. A carga fatorial é a correlação de cada variável (item ou questão da subescala) com o fator (construto, ou seja estresse, apoio social do companheiro e de outras pessoas, auto-estima).

Os valores obtidos através da avaliação das cargas fatoriais das subescalas do PPP-VP encontram-se na Tabela 15, e são assim apresentados já que as subescalas de estresse e auto-estima tiveram cargas fatoriais em mais de um fator.

Tabela 15 - Avaliação das cargas fatoriais das subescalas do PPP-VP. Porto Alegre, 2007

\begin{tabular}{lcccc}
\hline Subescala & Estresse & Apoio comp. & Apoio outras & Auto-estima \\
\hline Estresse & $-0,030$ a 0,691 & $-0,182$ a 0,032 & $-0,196$ a 0,058 & $-0,260$ a 0,030 \\
Apoio comp. & - & 0,746 a 0,870 & 0,064 a 0,202 & $-0,020$ a 0,214 \\
Apoio outras & - & - & 0,740 a 0,874 & $-0,081$ a 0,208 \\
Auto-estima & - & - & - & 0,039 a 0,750 \\
\hline
\end{tabular}

Baixas cargas fatoriais $(<0,30)$ na subescala de estresse foram encontradas nos itens 'Perda recente de alguém especial', 'Gestação atual', 'Estar sofrendo violência/abuso: sexual, emocional ou físico', 'Problemas com álcool e/ou drogas', e 'Problemas relacionados aos amigos'. Conforme visto na Tabela 5, é expressivo o 
percentual de gestantes que consideram que esses itens não causam nenhum estresse no seu cotidiano, justificando as baixas cargas fatoriais. Os itens 'Estar sofrendo violência/abuso...' e 'Problemas com álcool e/ou drogas' carregaram em um mesmo fator, demonstrando sua intercorrelação. Entretanto, o grande número de gestantes, $217(90 \%)$ e 207 (85,9\%) respectivamente, que afirmam que esses itens não geram nenhum estresse pode ser devido à negação desses sérios problemas sociais, em geral mantidos de forma velada. Curry, Campbell e Christian (1994) haviam encontrado baixas cargas fatoriais nos itens relacionados à 'Perda recente de alguém especial' e 'Problemas no trabalho' e atribuíram esses resultados ao fato de não ser uma ocorrência comum a morte de um ente querido e, em sua amostra, poucas mulheres trabalhavam fora. Acreditamos que todos os itens da subescala avaliam eventos do dia-a-dia que são potencialmente estressantes para as gestantes, sendo importante ressaltar que a subescala de estresse não teve nenhuma carga fatorial dividida em fatores de outras subescalas.

A subescala de auto-estima teve baixas cargas fatoriais em todos os itens cujas frases têm sua redação na forma negativa. Os itens 'No final das contas, você sente que é um fracasso' e 'Você sente que não tem muito do que se orgulhar' agruparam-se em um fator; e os itens 'Você queria ter mais respeito por si mesma', 'Às vezes você se sente inútil', e 'Às vezes, você acha que não é boa que chega' agruparam-se em outro, o que pode ser atribuído à grande semelhança semântica e à forte negatividade das sentenças. Conforme visto nos Quadros 2 e 3, a subescala de auto-estima foi aquela que mais gerou dúvidas nas respondentes, confundindo-as por vezes. Entretanto, a sentença que mais gerou respostas em branco (conforme a Tabela 8) e incompreensão em três gestantes (Quadro 2), 'Você tem uma atitude 
positiva consigo mesma', agrupou-se corretamente no mesmo fator que as demais afirmações e com carga fatorial de 0,750 .

O fato de as cargas fatoriais, das subescalas de apoio social recebido do companheiro e recebido de outras pessoas, carregarem todas em um mesmo fator, respectivamente, comprovam sua validade e, inclusive, reforçam sua validade de construto, pois todos os itens verificam, efetivamente, um mesmo construto.

\subsubsection{VALIDADE DE CONSTRUTO}

Para realizar a validação de construto do PPP-VP, foi realizada a análise da correlação entre as suas quatro subescalas, através da correlação de Pearson. Os valores obtidos encontram-se na Tabela 16.

Tabela 16 - Análise da correlação de Pearson entre as subescalas do PPP-VP. Porto Alegre, 2007

\begin{tabular}{lccc}
\hline Subescala & Apoio comp. & Apoio outras & Auto-estima \\
\hline Estresse & $-0,243^{* *}$ & $-0,244^{* *}$ & $-0,326^{* *}$ \\
Apoio comp. & - & $0,329^{* *}$ & $0,247^{* *}$ \\
Apoio outras & - & - & $0,159^{*}$ \\
\hline${ }^{* *} p<0,001$ & &
\end{tabular}

Conforme sugerido pela literatura, há correlação negativa significativa entre os escores da subescala de estresse do PPP em relação ao apoio social, tanto aquele recebido do companheiro quanto aquele recebido de outras pessoas. Também há correlação negativa do estresse com a subescala de auto-estima. Ou seja, a amostra de 241 gestantes confirma que o PPP tem validade de construto já que se verifica que quanto maior o apoio social (sendo mais significativo aquele recebido do companheiro do que o recebido de outras pessoas) e quanto mais elevada a auto-estima, menor será o estresse, conforme previsto na literatura. Há 
correlação positiva entre o apoio social, principalmente aquele oferecido pelo companheiro, e a auto-estima. Apesar de haver a correlação acima descrita, tanto negativa quanto positiva, entre os construtos avaliados por esta amostra de gestantes, a avaliação qualitativa da correlação, quanto à intensidade, é considerada de fraca a regular, conforme definição de Callegari-Jacques (2003). 


\section{CONCLUSÕES}

Os resultados do presente estudo nos permitiram tecer as conclusões que se seguem.

O instrumento Prenatal Psychosocial Profile (PPP), originalmente redigido em inglês, foi traduzido e adaptado culturalmente conforme os passos metodológicos preconizados pela literatura. Conforme a avaliação dos comitês de especialistas, a versão em português do Perfil Psicossocial do Pré-natal (PPP-VP) manteve a equivalência semântica, idiomática, cultural e conceitual do instrumento original, bem como apresenta validade de conteúdo e de face.

A amostra à qual o instrumento foi aplicado foi composta por 241 gestantes que utilizaram os serviços de pré-natal da rede básica de saúde de Porto Alegre (RS), entre novembro de 2006 e junho de 2007, com idade média de 26,4 anos, idade gestacional média de 29 semanas e escolaridade média de 9,3 anos.

A estatística descritiva das subescalas do PPP-VP para a amostra estudada demonstrou valores de média, desvio-padrão e amplitude de variação próximos aos das autoras quando da elaboração do instrumento.

As gestantes estudadas possuem baixos níveis de estresse, em média 18,84 (escore máximo de 44). Possuem bons níveis de apoio social, sendo maior aquele que percebem receber do parceiro, com média de 53,49 em relação ao apoio que recebem de outras pessoas, cuja média é de 50,33 (escore máximo de 66 para ambas subescalas). A auto-estima do grupo também é satisfatória, com média de 32,54 (escore máximo de 44).

As propriedades psicométricas do PPP foram mantidas após a tradução e adaptação transcultural do instrumento, com exceção da responsividade. 
Os valores do coeficiente de alfa de Cronbach encontrados no estudo foram próximos aos encontrados pelas autoras do PPP, e acima do preconizado pela literatura, mostrando que o instrumento manteve sua homogeneidade. Para esta amostra de gestantes moradoras de Porto Alegre (RS), os valores foram de 0,71 para a subescala de estresse, 0,96 para ambas subescalas de apoio social e 0,79 para a subescala de auto-estima.

As propriedades de estabilidade, avaliada através da reprodutibilidade, e de responsividade do instrumento, foram verificadas com amostras pequenas (27 e 29 gestantes, respectivamente) e acreditamos que por isto, bem como ao fato de ter sido reaplicado por telefone, possam ser explicadas as limitações para a obtenção de resultados mais satisfatórios.

A validade foi estabelecida através da análise fatorial e através da validade de construto. Os resultados mostraram que as cargas fatoriais carregaram-se conforme o esperado, pois nenhuma subescala teve algum item que carregou em fatores de outras subescalas, o que revela que cada subescala verifica construtos de seu próprio domínio.

Em relação à validade de construto, apesar de a avaliação qualitativa da intensidade da correlação ser considerada de fraca a moderada, foi encontrada uma correlação positiva entre apoio social e auto-estima e correlações negativas entre o estresse e a auto-estima, e entre o estresse e o apoio social justificando, portanto, o desenvolvimento do instrumento original e, também, a importância de sua tradução, adaptação transcultural e validação para futuro uso no Brasil. 


\section{CONSIDERAÇÕES FINAIS}

A preocupação com a atenção à gestante para além dos aspectos físicos e biológicos, valorizando aspectos sociais, emocionais e comportamentais é algo recente. O bem-estar psicossocial protege a mulher e seu concepto de situações adversas e é alcançado através de comportamentos que diminuam o risco à gestação. O apoio psicossocial é um dos fatores que permitem que se alcance bemestar psicossocial, diminuindo níveis de estresse e melhorando a auto-estima das gestantes. Algumas situações de pobreza, abandono social e familiar, difícil acesso à educação e cuidados básicos de saúde, pouco ou inadequado conhecimento sobre os riscos à gestação fazem com que algumas mulheres assumam comportamentos nocivos a ela e ao concepto.

O procedimento de adaptação e validação do Prenatal Psychosocial Profile com um grupo de gestantes brasileiras tornou-nos convictas de que o instrumento Perfil Psicossocial do Pré-natal permite avaliar o bem-estar psicossocial das gestantes na consulta pré-natal e, assim, desenvolver ações e intervenções que promovam a saúde materna e fetal.

Ressaltamos que optamos por utilizar nas subescalas do PPP-VP a forma coloquial de uso da língua portuguesa e não a forma padrão culta ao procurarmos obter a equivalência semântica e cultural do instrumento. A versão em português do PPP-VP que se encontra em anexo é apresentada assim como foi aplicada às gestantes. Foram retiradas as orientações ao coletador de dados que existem em sua versão original e, conseqüentemente, na back translation.

Destacamos que, apesar das dificuldades sociais e econômicas em nosso país, especialmente as vividas pelas classes mais desfavorecidas, os níveis de 
estresse desta amostra são baixos. Mesmo que para os parceiros e outras pessoas vinculadas às gestantes seja difícil dar a elas maior atenção durante uma fase especial de suas vidas, em ambas as subescalas de apoio social percebeu-se o desejo das gestantes de serem aceitas socialmente e de não desvalorizarem aquelas pessoas com quem mantêm vínculo estreito, mostrando-se satisfeitas com o apoio que percebem receber. Igualmente verificamos que a auto-estima é satisfatória, mesmo em situações familiares e sociais adversas, comuns às mulheres de baixa renda. Assim, pode-se inferir uma condição de aceitação, acomodação e/ou adaptação ao dia-a-dia.

Constatamos que o PPP-VP permite uma aproximação do profissional de saúde com a gestante, durante a consulta de pré-natal, através de uma abordagem pessoal e personalizada com cada gestante, valorizando os aspectos do dia-a-dia da mulher e considerando-a mais do que uma "barriga". Infelizmente sabe-se que a realidade cotidiana das Unidades Básicas de Saúde, somada ao desinteresse de alguns profissionais, não permite a valorização de aspectos psicossociais das vidas das gestantes, mantendo-se a prioridade dada aos aspectos biofísicos, mais especificamente com a gestação e o feto em desenvolvimento. Assim, além de humanizar a atenção pré-natal, ao criar vínculo e um ambiente de confiança com a gestante, a enfermeira obstétrica, ao aplicar o PPP, possibilita que a mulher verbalize questões íntimas ou veladas como situações de abuso (físico, verbal ou emocional), problemas de adição a drogas e álcool no contexto pessoal ou familiar, entre outros temas.

Verificamos que a aplicação do PPP-VP no ambiente de consulta de pré-natal favorece o desenvolvimento do processo de enfermagem, a começar pela coleta dos dados, possibilita a formação de vínculo da gestante com a enfermeira e 
conseqüentemente com o serviço de saúde. A formação e manutenção do vínculo são primordiais para a adesão ao cuidado pré-natal, e conseqüentemente, para a diminuição dos riscos inerentes ao período perinatal. No entanto, cabe destacar a importância de favorecer as condições de privacidade para que cada um dos construtos do PPP-VP possa ser adequadamente trabalhado. Assim, recomendamos que o instrumento não seja auto-aplicado, para favorecer uma fluidez na conversação e vínculo com a gestante e para o esclarecimento de dúvidas, reforçando que não existem respostas corretas, mas sim aquelas adequadas à situação pessoal de cada gestante. Da mesma forma, sugerimos que durante a aplicação do PPP-VP a gestante esteja sozinha, para que se sinta à vontade ao responder itens pertinentes a questões pessoais e familiares. Por outro lado, sugerimos que a aplicação do instrumento não aconteça por telefone, o que pode gerar distanciamento e dificuldades, por vezes, de explicar os itens e de repetição de suas possíveis respostas.

As autoras (CURRY; CAMPBELL; CHRISTIAN, 1994) sugerem o uso de cartões com 'carinhas' (por exemplo: :;, ()) para facilitar as respostas das gestantes. Embora não tenhamos usado tal estratégia, acreditamos que possa ser muito útil, especialmente entre gestantes com baixa escolaridade, e nos itens das subescalas de apoio social, cujas respostas variam de 1 a 6 , com 1 correspondendo a 'muito insatisfeita' e 6 'muito satisfeita'. Isto porque como não há uma resposta específica atribuída para cada valor possível (1 a 6), as respostas tendem a ser pontuadas nas extremidades, ou seja, naquelas que têm um conceito atribuído ao valor.

A substituição das respostas à subescala de estresse para 'nenhum', 'algum', 'moderado' e 'intenso', conforme sugestão de uma gestante, pode ser uma 
alternativa para se alcançar uma equivalência idiomática mais adequada, visto representar uma linguagem mais coloquial para a população brasileira.

Outra sugestão em relação à semântica do instrumento é alterar o item $\mathrm{F}$ da subescala de estresse, 'Gestação atual', para afirmação 'Gestação atual como um todo', para reforçar as implicações sociais e familiares da gestação e não apenas o aspecto biológico.

De forma semelhante às autoras do PPP, neste estudo a subescala de estresse foi a que apresentou menor valor do coeficiente de alfa de Cronbach. As preocupações financeiras da gestante e da família foram as principais causadoras de estresse entre a amostra estudada. Embora o PPP tenha sido desenvolvido para ser usado com gestantes de baixa renda e condições socioeconômicas desfavoráveis, existem diferenças significativas, por exemplo, entre o sistema de saúde pública dos Estados Unidos, país de origem do PPP, e do sistema de saúde pública do Brasil. Podemos citar que os investimentos com saúde naquele país são da ordem de 15,4\% do Produto Interno Bruto (PIB) ao ano, enquanto que, no Brasil, este valor é de apenas $8,8 \%$ do PIB (WHO, 2007). Outros fatores poderiam também ser considerados, como a renda per capita, o número de componentes da família, o poder de compra dessa família, etc.

A subescala de auto-estima foi a considerada mais difícil pelas gestantes desta amostra, que se confundiram com as frases redigidas de forma negativa, ou reversa. Esta foi a subescala com maior número de não-respostas e a mais citada pelas gestantes como de difícil compreensão. Nesta subescala, o valor do coeficiente alfa de Cronbach obtido nesta amostra $(0,79)$ foi menor que o obtido pelas autoras $(0,89)$. Acreditamos que além da redação de maneira reversa, talvez seja necessário rever a conceptualização de auto-estima em diferentes contextos, 
culturas e etnias. Como as próprias autoras (CURRY; BURTON; FIELDS, 1998) sugerem, o conceito utilizado na subescala de auto-estima talvez seja inapropriado para alguns grupos culturais, conclusão alcançada após obterem resultados variados em estudo comparativo com diferentes grupos culturais nos Estados Unidos (nativas americanas da área rural, hispânicas da área rural, caucasianas de área rural, afro-americanas, entre outros).

É importante ressaltar que nesta amostra não houve especificação de etnia nem de classe social das gestantes que preencheram o PPP-VP, entretanto a amostra pode ser considerada homogênea se considerarmos que, em geral, no Brasil, e mais especificamente em Porto Alegre (RS), onde o uso do instrumento foi validado, os usuários da rede básica de saúde são pertencentes às classes sociais menos favorecidas. Curry, Campbell e Christian (1994) aplicaram o PPP principalmente em gestantes de baixa renda.

O processo de adaptação e validação do PPP para uso no Brasil nos permite concordar com Curry, Campbell e Christian (1994) quando sugerem que é possível obter através do PPP um escore de risco psicossocial. Este escore pode ser obtido já que as quatro subescalas mostraram ser inter-relacionadas apesar de serem independentes. Para se obter este, valor deve-se transformar as escalas de Likert de seis pontos das subescalas de apoio social em escalas de quatro pontos. Posteriormente, as subescalas de apoio social e de auto-estima devem ter seus escores revertidos. Assim, maiores valores correspondem a maior risco psicossocial, pois revelam maior estresse, menor apoio social e menor auto-estima.

Em uma próxima etapa de estudos, pretende-se testar este escore de risco psicossocial. Assim, poderemos verificar a validade critério do PPP-VP, através da sua validade preditiva, ou seja, o instrumento será aplicado durante o pré-natal e 
posteriormente essas gestantes serão reavaliadas em relação aos desfechos da gestação. Acreditamos que, por meio de um escore de risco psicossocial, poderemos desenvolver intervenções que levem à mudança de comportamentos de risco à gestação, como uso de álcool, tabaco e outras substâncias ilícitas, além de oferecer apoio emocional. Conseqüentemente será possível diminuir, por exemplo, os riscos de prematuridade, de baixo peso ao nascimento e depressão pós-parto, importantes geradores não só de ônus financeiro ao Estado e às famílias, mas também de vínculos enfraquecidos ou inexistentes e baixa qualidade de vida para mãe, filho e família.

Igualmente, ressaltamos que, em nosso país, os recursos financeiros destinados à saúde são escassos, sendo necessária e premente a utilização de meios facilitadores de avaliação da população que sejam confiáveis e pouco dispendiosos, como o PPP-VP. Assim, sugerimos um estudo multicêntrico no Brasil para traçar o perfil psicossocial das gestantes, com posterior desenvolvimento de ações e intervenções de cuidado à gestante, seu concepto e sua família.

Finalmente, gostaríamos de salientar que ao disponibilizar o PPP, traduzido para o português, adaptado culturalmente, testado e validado com um grupo de gestantes moradoras de Porto Alegre (RS), para profissionais de saúde na atenção pré-natal, abrem-se novos campos de pesquisa que levam a um aprofundamento no conhecimento sobre a influência dos fatores psicossociais na determinação dos fatores de risco à gestação. 


\section{REFERÊNCIAS}

AARONSON, Lauren S. Perceived and received support: effects on health behavior during pregnancy. Nursing Research, Hagerstown, MD, v. 38, n. 1, p. 4-9, jan.-fev. 1989.

ALEXANDRE, Neusa Maria Costa; GUIRARDELLO, Edinêis de Brito. Adaptación cultural de instrumentos utilizados em salud ocupacional. Revista Panamericana de Salud Publica, s.l., v. 11, n. 2, p. 109-111, 2002.

AUMANN, Gretchen M. E.; BAIRD, Margaret M. Avaliação do risco em gestantes. In: KNUPPEL, Robert A.; DRUKKER, Joan E. Alto risco em obstetrícia: um enfoque multidisciplinar. 2. ed. Porto Alegre: Artes Médicas, 1996. Cap. 2, p. 13-36.

BEATON, Dorcas E.; BOMBARDIER, Claire; GUILLEMIN, Francis; FERRAZ, Marcos Bosi. Guidelines for theprocess of cross-cultural adaptation of self-report measures. Spine, s.I., v. 25, n. 24, p. 3186-3191, 2000.

BONILLA, Astrid Olivar. Cambios biológicos, psicológicos y sociales durante el embarazo. Rev. Fed. Odontol. Colomb., v. 201, p. 37-51, oct. 2001-feb. 2002. tab. Acessado em <http://www.encolombia.com/odontologia/foc/foc20102-cambios.htm>, em 30 mar. 2007.

BRANDEN, Pennie S. Enfermagem materno-infantil. 2. ed. Rio de Janeiro: Reichmann \& Affonso, 2000.

BRASIL. Ministério da Saúde. Gestação de alto risco: manual técnico. 3. ed. Brasília: Ministério da Saúde, 2000.

BRASIL. Ministério da Saúde. Datasus: indicadores de saúde. Disponível em <http://tabnet.datasus.gov.br/cgi/idb2004/matriz.htm?saude=http\%3A\%2F\%2Ftabnet .datasus.gov.br\%2Fcgi\%2Fidb2004\%2Fmatriz.htm\&obj=\%24VObj\&botaook=OK\#mo rb>. Acesso em 26 out. 2005.

BRASIL. Ministério da Saúde. Assistência pré-natal: manual técnico. 3. ed. Brasília: Ministério da Saúde. 2006.

BROWN, Mary Annette. Social support during pregnancy: a unidimensional or multidimensional construct? Nursing Research, Hagerstown, MD, USA, v. 35, n. 1, p. 4-9, jan.-feb., 1986a.

BROWN, Mary Annette. Social support, stress, and health: a comparision of expectant mothers and fathers. Nursing Research, Hagerstown, MD, USA, v. 35, n. 2, p. 72-76, 1986b.

BULLINGER, Monika; et al. Translating health status questionnaires and evaluating their quality: the IQOLA project approach. Journal of Clinical Epidemiology, s.I., v. 51, n. 11, p. 913-923, 1998. 
CALLEGARI-JACQUES, Sídia M. Bioestatística: princípios e aplicações. Porto Alegre: Artmed, 2003.

CASHION, Kitty. Gestação de risco: condições gestacionais. In: LOWDERMILK, Deitra L.; PERRY, Shannon E.; BOBAK, Irene M. O cuidado em enfermagem materna. 5.ed. Porto Alegre: Artmed, 2002. Cap. 24, p. 648-698.

CHWALOW, A. Judith. Cross-cultural validation of existing quality of life scales. Patient Education and Counseling, s.I., v. 26, p. 313-318, 1995.

CICONELLI, Rozana Mesquita. Tradução para o português do questionário genérico de avaliação de qualidade de vida "Medical Outcomes Study 36-item Short-Form Health Survey (SF-36)". Tese (Doutorado). Universidade Federal de São Paulo. Escola Paulista de Medicina. Curso de Doutorado em Medicina. 1997. 143f.

CONNELLY, Cynthia Donaldson. Hopefulness, self-esteem, and perceived social support among pregnant and nonpregnant adolescents. Western Journal of Nursing Research, s.I., v. 20, n. 2, p. 195-209, 1998.

CURRY, Mary Ann; CAMPBELL, Ruth Ann; CHRISTIAN, Megan. Validity and reliability testing of the prenatal psychosocial profile. Research in Nursing \& Health, Hoboken, NJ, v. 17, p. 127-135, 1994.

CURRY, Mary Ann; BURTON, Deborah; FIELDS, Jonathan. The prenatal psychosocial profile: a research and clinical tool. Research in Nursing \& Health, Hoboken, NJ, v. 21, p. 211-219, 1998.

CURRY, Mary Ann. The interrelationships between abuse, substance use, and psychosocial stress during pregnancy. Journal of Obstetric, Gynecologic and Neonatal Nursing, Thousand Oaks, CA, v. 27, p. 692-699, 1998.

CURRY, Mary Ann; DURHAM, Laurel; BULLOCK, Linda; BLOOM, Tina; DAVIS, Jan. Nurse case management for pregnant women experiencing or at risk for abuse. Journal of Obstetric, Gynecologic and Neonatal Nursing, Thousand Oaks, CA, v. 35 , n. 2, p. 181-192, 2006.

DINI, Gal Moreira. Adaptação cultural, validade e reprodutibilidade da versão brasileira da escala de auto-estima de Rosenberg. Dissertação (Mestrado). Universidade Federal de São Paulo. Escola Paulista de Medicina. Curso de Mestrado em Cirurgia Plástica Reparadora. 2000. $102 f$.

EUSTACE, Larry W.; KANG, Duck-Hee; COOMBS, David. Fetal alcohol syndrome: a growing concern for health care professionals. Journal of Obstetrics, Gynecology and Neonatal Nursing, Thousand Oaks, CA, v. 32, n. 2, p. 215-226, mar.-apr. 2003.

FAYERS, Peter M.; MACHIN, David. Quality of life: assessment, analysis and interpretation. West Sussex, England: John Wiley \& Sons, 2000.

FRIED, Peter A. Clinical implications for smoking: determining long-term teratogenicity. In: ZAGON, lan S.; SLOTKIN, Theodore A. (editors) Maternal substance abuse and the developing nervous system. San Diego: Academic Press, 1992. Cap. 5, p. 77-96. 
FUNARO, Vânia M. B. de O. (coord.) et al. Diretrizes para apresentação de dissertações e teses da USP: documento eletrônico e impresso. São Paulo: SIBiUSP, 2004. Disponível em: <http://www.bcrp.pcarp.usp.br>. Acesso em 16 mar. 2005.

GANDEK, Barbara; WARE, John E. Methods for validating and norming translations of health status questionnaires: the IQOLA project approach. Journal of Clinical Epidemiology, s.I., v. 51, n. 11, p. 953-959, 1998.

GILBERT, Elizabeth, S.; HARMON, Judith S. Manual prático de gravidez e parto de alto risco. 2. ed. Rio de Janeiro: Revinter, 2002.

GRADY, Deborah; NEWMAN, Thomas B.; VITTINGHOFF, Eric. Gerenciamento de dados. In: HULLEY, Stephen B.; CUMMINGS, Steven R.; BROWNER, Warren; GRADY, Deborah; HEARST, Norman; NEWMAN, Thomas B. Delineando a pesquisa clínica: uma abordagem epidemiológica. 2.ed. Porto Alegre: Artmed, 2003. Cap. 16, p. 283-294.

GREENBERG, Jeff; SOLOMON, Sheldon; PYSZCZYNSKI, Tom; et al. Why do people need self-esteem? Converging evidence that self-esteem serves as an anxiety-buffering function. Journal of Personality and Social Psychology, s.I., v. 63, n. 6, p. 913-922, 1992.

GRIEP, Rosane Harter; CHOR, Dóra; FAERSTEIN, Eduardo; WERNECK, Guilherme L.; LOPES, Cláudia S. Validade de constructo de escala de apoio social do Medical Outcomes Study adaptada para o português no Estudo Pró-Saúde. Cad. Saúde Pública. Rio de Janeiro, v. 21, n. 3, p. 703-714, mai-jun, 2005.

GUILLEMIN, Francis. Cross-cultural adaptation and validation of health status measures. Scandinavian Journal of Rheumatology, s.I., n. 24, p. 61-63 (editorial review), 1995.

HARLEY, Kim; ESKENAZI, Brenda. Time in the United States, social support and health behaviors during pregnancy among women of Mexican descent. Social Science and Medicine, Great Britain, v. 62, p. 3048-3061, 2006.

HEAMAN, Maureen I.; BLANCHARD, James F.; GUPTON, Annette L.; MOFFATT, Michael E. K.; CURRIE, Raymond F. Risk factors for spontaneous preterm birth among Aboriginal and non-Aboriginal women in Manitoba. Paediatric and Perinatal Epidemiology, s.l., v. 19, p. 181-193, 2005.

HELMAN, Cecil G. Culture, health and illness. 4. ed. Oxford (Engand): ButterworthHeinemann, 2000.

HERDMAN, M.; FOX-RUSHBY, J.; BADIA, X. 'Equivalence' and the translation and adaptation of heatlh-related quality of life questionnaires. Quality of life research, s.I., v. 6, p. 237-247, 1997.

ISTVAN, Joseph. Stress, anxiety, and birth outcomes: a critical review of the evidence. Psychological Bulletin, Washington, DC, v. 100, n. 3, p. 331-348, 1986. 
JESSE, D. Elizabeth; ALLIGOOD, Martha R. Holistic obstetrical problem evaluation (HOPE): testing a theory to predict birth outcomes in a group of women from Appalachia. Health Care for Women International, Philadelphia, PA, v. 23, p. 587599, 2002.

JESSE, D. Elizabeth; REED, Pamela G. Effects of spirituality and psychosocial wellbeing on health risk behaviors in Appalachian pregnant women. Journal of Obstetric, Gynecologic and Neonatal Nursing, Thousand Oaks, CA ,v.33, n. 6, p. 739-747, nov.-dec. 2004.

JESSE D. Elizabeth; SEAVER, William; WALLACE, Debra C. Maternal psychosocial risks predict preterm birth in a group of women from Appalachia. Midwifery, s.I., v. 19, p. 191-202, 2003.

JESSE, D. Elizabeth; WALCOTT-McQUIGG, Jacqueline; MARIELLA, Anne; SWANSON, Melvin S. Risks and protective factors associated with symptoms of depression in low-income African American and Caucasian women during pregnancy. Journal Midwifery Womens Health, s.l., v. 50, n. 5, p. 405-410, 2005.

JOHNSTON, Brian D.; HUEBNER, Colleen E.; TYLL, Lynda T; BARLOW, William E.; THOMPSON, Robert S. Expanding developmental and behavioral services for newborns in primary care: effects on parental well-being, practice and satisfaction. American Journal of Preventive Medicine, s.l., v. 26, n. 4, p. 356-366, 2004.

MALONI, Judith A.; ALBRECHT, Susan A.; THOMAS, Karen K.; HALLERAN, JoAnn; JONES, Renee. Implementing evidence-based practice: reducing risk for low birth weight through pregnancy smoking cessation. Journal of Obstetrics, Gynecology and Neonatal Nursing, Thousand Oaks, CA, v. 32, n. 5, p. 676-682, sep.-oct. 2003.

MEURER, Jeanne; TAREN, Douglas R. Prevenção e saúde em obstetrícia. In: KNUPPEL, Robert A.; DRUKKER, Joan E. Alto risco em obstetrícia: um enfoque multidisciplinar. 2. ed. Porto Alegre: Artes Médicas, 1996. Cap. 3, p. 37-45.

MOREIRA, Mariana Calesso; SARRIERA, Jorge Castellá. Preditores de saúde e bem-estar psicológico em adolescentes gestantes. Psico-USF, v. 11, n. 1, p. 7-15, jan-jun, 2006.

MPHIL, Paul Kind (coor.). The measurement of quality of life in quality of life clinical trials: considerations of good research practice. A draft for discussion. A report of the ISPOR Health Science Committee - task force on good research practices - quality of life studies. York, England: University of York, 2001.

NORBECK, Jane S.; ANDERSON, N. Jean. Psychosocial predictors of pregnancy outcomes in low-income black, hispanic, and white women. Nursing Research, Hagerstown, MD, v. 38, n. 4, p. 204-209, jul.-ago. 1989.

NORBECK, Jane S.; DEJOSEPH, Jeanne F.; SMITH, Renée T. A randomized trial of an empirically-derived social support intervention to prevent low birthweight among African American women. Social Science and Medicine, Great Britain, v. 43, n. 6, p. 947-954, 1996. 
OAKLEY, Ann; RAJAN, Lynda; GRANT, Adrian. Social support and pregnancy outcome. British Journal of Obstetrics and Gynaecology, London, v. 97, p. 155-162, feb. 1990 .

PASQUALI, Luiz (org.). Técnicas de exame psicológico - TEP Manual. Volume I: Fundamentos das técnicas psicológicas. São Paulo: Casa do Psicólogo, 2001.

POLIT, Denise F.; HUNGLER, Bernadette P. Essentials of nursing research: methods, appraisal, and utilization. 4 ed. Philadelphia: Lippincott-Ravens, 1997.

RAINES, Deborah A.; MORGAN, Zara. Culturally sensitive care during childbirth. Applied Nursing Research, s.l., v. 13, n. 4, p. 167-172, nov. 2000.

RAPHAEL-LEFF, Joan. Gravidez: a história interior. Porto Alegre: Artes Médicas, 1997.

REED, Pamela G. Religiousness among terminally ill and healthy adults. Research in Nursing \& Health, Hoboken, NJ, v. 9, p. 35-41, 1986.

ROMERO, Rosa Maria Díaz; FIGUEROA, Victor Daniel Aguilar; GARCÍA, Roberto Santillán. Estrés y embarazo. Revista de lá Asociación Dental Mexicana. Cidade do México, v. 54, n. 1, p. 27-31, enero-febrero, 1999.

ROSENBERG, Morris. Society and the adolescent self-image. Princeton, NJ: Princeton University Press, 1965.

RUIZ, Roberta J.; FULLERTON, Judith T. The measurement of stress in pregnancy. Nursing and Health Sciences, Oxford, England, v. 1, p. 19-25, 1999.

SCHIRMER, Janine; SUMITA, Satie L. N.; FUSTINONI, Suzete M. Cuidados especiais no ciclo grávido-puerperal de alto-risco. In: BARROS, Sônia M. O.; MARIN, Heimar de F.; ABRÃO, Ana Cristina F. V. Enfermagem obstétrica e ginecológica: guia para prática assistencial. São Paulo: Roca, 2002.

SCHMIDT, Silke; BULLINGER, Monika. Current issues in cross-cultural quality of life instruments development. Archives of Physical Medicine and Rehabilitation, s.l., v. 84, suppl. 2, p. S29-S34, apr. 2003.

SCHROEVERS, Maya J.; RANCHOR, Adelita V.; SANDERMAN, Robbert. The role of social support and self-esteem in the presence and course of depressive symptoms: a comparison of cancer patients and individuals from the general population. Social Science and Medicine, Great Britain, v. 57, p. 375-385, 2003.

SINCLAIR, Barbara Peterson. Promoção e prevenção de saúde. In: LOWDERMILK, Deitra L.; PERRY, Shannon E.; BOBAK, Irene M.. O cuidado em enfermagem materna. 5.ed. Porto Alegre: Artmed, 2002. Cap. 4, p. 57-79.

SPERBER, Ami. Translation and validation of study instruments for cross-cultural research. Gastroenterology, s.I., v. 126, p. 124-128, 2004. 
STREINER, David L.; NORMAN, Geoffrey R.. Health measurement scales: a practical guide to their development and use. 2.ed. Oxford: Oxford University Press, 1995.

STREISSGUTH, Ann P. Fetal alcohol syndrome and fetal alcohol effects: a clinical perspective of later developmental consequences. In: ZAGON, lan S.; SLOTKIN, Theodore A. (editors) Maternal substance abuse and the developing nervous system. San Diego: Academic Press, 1992. Cap. 2, p. 2-25.

THOITS, Peggy A. Stress, coping and social support processes: where are we? What next? Journal of Health and Social Behavior, s.I. Extra Issue, p. 53-79, 1995.

TIRAN, Denise; CHUMMUN, Harry. Complementary therapies to reduce physiological stress in pregnancy. Complementary Therapies in Nursing and Midwifery, s.l., v. 10, p.162-167, 2004.

UNIVERSITY OF MARYLAND. Department of Sociology. The Rosenberg SelfEsteem Scale. Disponível em

<http://www.bsos.umd.edu/socy/grad/socpsy_rosenberg.html>. Acesso em 14 mai. 2007.

WARE, John E.; GANDEK, Barbara. Methods for testing data quality, scaling assumptions, and reliability: the IQOLA project approach. Journal of Clinical Epidemiology, s.I., v. 51, n. 11, p. 945-952, 1998.

WEISMAN, Carol S.; HILLEMEIER, Marianne M; CHASE, Gary A.; DYER, AnneMarie; et al. Preconceptional health: risks of adverse pregnancy outcomes by reproductive life stage in the Central Pennsylvania Women's Health Study (CePAWHS). Women's Health Issues, Washington, DC, v. 16, p. 216-224, 2006.

WEISSHEIMER, Anne Marie. O parto na cultura teuto-gaúcha. Dissertação (Mestrado). Universidade Federal do Rio Grande do Sul. Escola de Enfermagem. Curso de Mestrado em Enfermagem. 2002. 127f.

WHO. Countries statistics 2007 . Disponível em <http://www.who.int/countries/>. Acesso em 05 set. 2007.

WHO. Well-being Disponível em $<$ http://www.who.int/globalchange/publications/millassess.pdf>. Acesso em 20 jul. 2005. 
APÊNDICES 


\title{
APÊNDICE A
}

\author{
Manual de Orientações Para Coleta de Dados
}

Projeto de tese de Anne Marie Weissheimer, "Correlação do bem-estar psicosocial e da espiritualidade com comportamentos de risco à gestação: tradução, adaptação e validação para uso no Brasil dos instrumentos Prenatal Psychosocial Profile e Spiritual Perspective Scale".

- Após contato prévio da pesquisadora com a Gerência Distrital e a chefia de enfermagem das Unidades de Saúde, o coletador irá apresentar-se na Unidade, munido do Parecer do Comitê de Ética em Pesquisa da SMS de Porto Alegre e carta de apresentação;

- Consultar na Unidade a agenda de pré-natal, verificando os dias e horários de maior demanda para proceder à coleta nestes dias e horários;

- Verificar a possibilidade de haver área apropriada para a coleta;

- Abordar as gestantes enquanto aguardam a consulta de pré-natal, convidando-as a participar da pesquisa, explicando de forma geral do que se trata;

- A idade mínima das gestantes é de 18 anos;

- A idade gestacional deve ser de 12 a 40 semanas;

- Havendo aceitação, adaptar-se para o melhor momento de coleta de dados, se imediatamente, se logo após a consulta ou se em outro momento;

- Ler, explicar e assinar o Termo de Consentimento Livre e Esclarecido em duas vias, fornecendo uma à gestante;

- Verificar com a gestante a sua habilidade em ler e escrever, pois o instrumento PPP pode ser auto-aplicado;

- Após a aplicação do PPP, questionar a gestante sobre a sua compreensão do instrumento, instruções, frases e respostas, anotando no instrumento específico (Avaliação do PPP), para que seja possível realizar uma análise qualitativa da adaptação para a língua portuguesa do instrumento (essa avaliação somente será realizada com os 30 primeiros instrumentos de toda a amostra);

- Numerar os quatro instrumentos corretamente com o mesmo número de identificação, com o primeiro dígito correspondendo à Gerência Distrital a qual pertence a Unidade de Saúde; ter certeza de que os quatro instrumentos estão numerados e contêm dados/informações de uma mesma pessoa;

- Coletar dados no prontuário e com a gestante para o preenchimento do instrumento "Dados de identificação, clínicos e obstétricos";

- Orientar para que ignorem as "palavras" e "quadrinhos" colocados à direita e que são de uso exclusivo dos pesquisadores;

- Esclarecer que o nome e o número de telefone de contato serão usados APENAS para esclarecer eventuais dúvidas sobre a gestação, exames e hábitos.

\section{Dados de identificação, clínicos e obstétricos}

Em relação a este instrumento, proceder à coleta dos dados no prontuário ou na carteira de pré-natal da gestante, esclarecendo dúvidas com a gestante em relação ao peso, por exemplo, se necessário.

Os dados obstétricos referem-se a todo histórico obstétrico, a gestação atual INCLUSIVE! Por exemplo, no item 9, se esta for a primeira gestação, preenche-se (88) NSA (não se aplica), pois não há paridade prévia! Idem para os itens 10 e 11. 


\section{Perfil Psicosocial no Pré-natal}

Conforme já citado anteriormente, verificar a habilidade da gestante em ler e escrever e COMPREENDER o instrumento.

Dar instruções sobre o seu preenchimento: que devem ler o cabeçalho e, após, ler cada frase circulando a resposta mais apropriada para a sua situação pessoal. Reforçar que NÃO há resposta certa ou errada, mas a resposta adequada para a sua situação pessoal. Oferecer-se para explicar os itens, se por acaso não compreenderem o que o mesmo quer dizer.

Avaliação do estresse: - o item E pode referir-se a perda por morte ou ruptura (separação) de alguém;

- o item G refere-se a qualquer tipo de violência (agressão verbal ou deboche, por exemplo, etc.);

- o item I refere-se também a más condições de trabalho.

Avaliação do apoio: as seguintes orientações fazem parte do intrumento original, conforme encaminhado pela autora Mary Ann Curry. "Se as mulheres têm companheiro, esta série de questões é primeiramente feita em relação ao companheiro. As mulheres avaliam seu companheiro em uma escala de 1 a 6 , com 1 correspondendo a 'muito insatisfeita' e 6 correspondendo a 'muito satisfeita'. Depois, elas são questionadas com a mesma série de perguntas, mas lhes é solicitado que respondam com base no quanto se sentem satisfeitas com o apoio que recebem de outras pessoas. Se as mulheres não têm companheiro, a primeira série de perguntas é omitida e as perguntas são feitas apenas uma vez. Os maiores escores indicam maior satisfação com o apoio."

Reforçar que o setor divide-se em duas partes, a primeira só deve ser preenchida se a gestante tem companheiro!! As repostas variam desde 'muito insatisfeita' até 'muito satisfeita' e a gestante deve escolher com que "intensidade" sente-se em relação a cada frase, ou seja, se acha que seu companheiro ou outras pessoas se comportam de tal forma com ela, mais ou menos. Posteriormente, as mesmas frases devem ser respondidas TODAS DE NOVO em relação a outras pessoas: amigos, pais, irmãos, colegas de trabalho, pessoas de convívio da gestante em geral!

O item J refere-se a situação geral da gestação.

Avaliação da auto-estima: este setor pode confundir as gestantes, pois algumas das frases estão colocadas de forma negativa, procurando assim verificar se elas realmente lêem TODAS as frases. Este fato não deve ser verbalizado a elas, mas se elas mostrarem dúvidas, esclarecer que a frase é assim mesmo, e perguntar como se sentem em relação a isso. 


\section{APÊNDICE B}

Número:

Dados de Identificação, Clínicos e Obstétricos
A) Dados de identificação:
1) Nome:
2) $\mathrm{N}^{\circ}$ prontuário família:
3) $\mathrm{N}^{\circ}$ prontuário gestante:
4) Telefone para contato:
5) Data da coleta dos dados:
6) Idade da gestante (anos )
7) Escolaridade (até que série estudou):

B) Dados obstétricos:
8) Idade gestacional (semanas):
$\begin{array}{ll}\text { 9) DUM: } \\ \text { 10) Número de gestações: }\end{array}$
$\begin{array}{ll}\text { 11) Paridade: } \\ \text { 12) Parto vaginal: }\end{array}$

13) Abortos: (88) NSA

14) Número de consultas de pré-natal (inclusive hoje):

15) Alguma complicação na gestação: (1)SIM (2)NÃO

16) Qual?

17) Uso de medicação no momento: (1)SIM (2)NÃO

18) Qual?

19) Pré-natal nas gestações anteriores? (1)SIM (2)NÃO (88)NSA

20) Complicações nas gestações anteriores? (1)SIM (2)NÃO (88)NSA

21) Quais?

C) Dados clínicos:

22) Peso atual (em kg):

23) Peso anterior à gestação ou ao iniciar $\mathrm{PN}$ :

24) Pressão arterial atual: sistólica diastólica

25) Pressão arterial na primeira consulta: sistólica diastólica

26) Altura uterina na data da coleta de dados (em $\mathrm{cm})$ :
IDADEMAE

IDADEGES

GESTACOE

PARIDADE

PARTOVAG

PARTOCES

ABORTOSP

NUMCONPN

COMGESAT

MEDIMOME

PNGESANT

COMGESAN

PESOATUA

PESOANTE

PASISTAT

PADIASAT

PASISTAN

PADIASAN

AUDATCOL

Observações:

Coletador(a): 


\section{APÊNDICE C}

Glossário Codificação Pesquisa

\section{DADOS IDENTIFICAÇÃO, CLÍNICOS E OBSTÉTRICOS}

\begin{tabular}{|l|l|l|}
\hline \multicolumn{1}{|c|}{ VARIÁVEL } & SIGNIFICADO & PREENCHIMENTO \\
\hline A) & & \\
\hline IDADEMAE & Idade da gestante & em anos \\
\hline ESCOLARI & Escolaridade & em anos \\
\hline B) & & \\
\hline IDADEGES & Idade gestacional & em semanas \\
\hline GESTACOE & Número de gestações & em números \\
\hline PARIDADE & Número de vezes que pariu & em números \\
\hline PARTOVAG & Número de partos vaginais & em números \\
\hline PARTOCES & Número de partos cesáreos & em números \\
\hline ABORTOSP & Número de abortos, espontâneos ou provocados & em números \\
\hline NUMCONPN & Número de consultas de pré-natal, incluindo a atual & em números \\
\hline COMGESAT & Presença de complicações na gestação atual & $(1)$ sim (2) não \\
\hline MEDIMOME & Uso de medicamentos no momento & $(1)$ sim (2) não \\
\hline PNGESANT & Realização de pré-natal em gestações anteriores & $(1)$ sim (2) não (88) NSA \\
\hline COMGESAN & Presença de complicações nas gestações anteriores & $(1)$ sim (2) não (88) NSA \\
\hline C) & & \\
\hline PESOATUA & Peso atual & em quilogramas \\
\hline PESOANTE & Peso anterior à gestação ou ao iniciar o PN & em quilogramas \\
\hline PASISTAT & Pressão sistólica atual & em mmHG \\
\hline PADIASAT & Pressão diastólica atual & em mmHG \\
\hline PASISTAN & Pressão sistólica ao iniciar PN & em mmHG \\
\hline PADIASAN & Pressão diastólica ao iniciar PN & em mmHG \\
\hline AUDATCOL & Altura uterina no dia da coleta dos dados & em centímetros \\
\hline
\end{tabular}


PERFIL PSICOSOCIAL NO PRÉ-NATAL

\section{Avaliação do Estresse}

\begin{tabular}{|l|l|l|}
\hline VARIÁVEL & SIGNIFICADO & PREENCHIMENTO \\
\hline PREOCFIN & Preocupações financeiras & $\begin{array}{l}\text { (1)nenhum (2)algum } \\
(3) \text { moderado (4)intenso }\end{array}$ \\
\hline OUTPREOC & Outras preocupações com dinheiro & $\begin{array}{l}\text { (1)nenhum (2)algum } \\
(3) \text { moderado (4)intenso }\end{array}$ \\
\hline PROBFAMI & Problemas relacionados à família & $\begin{array}{l}((1) \text { nenhum (2)algum } \\
\text { (3)moderado (4)intenso }\end{array}$ \\
\hline MUDAREND & Mudança de endereço (passada ou futura) & $\begin{array}{l}\text { (1)nenhum (2)algum } \\
(3) \text { moderado (4)intenso }\end{array}$ \\
\hline PREDRECE & Perda recente de alguém especial & $\begin{array}{l}\text { (1)nenhum (2)algum } \\
(3) \text { moderado (4)intenso }\end{array}$ \\
\hline GESTATUA & Gestação atual & $\begin{array}{l}(1) \text { nenhum (2)algum } \\
(3) \text { moderado (4)intenso }\end{array}$ \\
\hline SOFRVIAB & Sofrer de violência ou abuso & $\begin{array}{l}(1) \text { nenhum (2)algum } \\
(3) \text { moderado (4)intenso }\end{array}$ \\
\hline ALCODROG & Problemas com álcool e/ou drogas & $\begin{array}{l}\text { (1)nenhum (2)algum } \\
(3) \text { moderado (4)intenso }\end{array}$ \\
\hline PROBTRAB & Problemas no trabalho & $\begin{array}{l}(1) \text { nenhum (2)algum } \\
(3) \text { moderado (4)intenso }\end{array}$ \\
\hline PROBAMIG & Problemas relacionados aos amigos & $\begin{array}{l}(1) \text { nenhum (2)algum } \\
(3) \text { moderado (4)intenso }\end{array}$ \\
\hline SOBRECAR & Sentir-se sobrecarregada & $\begin{array}{l}(1) \text { nenhum (2)algum } \\
(3) \text { moderado (4)intenso }\end{array}$ \\
\hline
\end{tabular}

\section{Avaliação do apoio social}

\begin{tabular}{|c|l|l|}
\hline VARIÁVEL & SIGNIFICADO & PREENCHIMENTO \\
\hline COMPANHE & Tem companheiro & (1) Não (2) Sim \\
\hline
\end{tabular}

Apoio do companheiro

\begin{tabular}{|l|l|l|}
\hline \multicolumn{1}{|c|}{ VARIÁVEL } & SIGNIFICADO & PREENCHIMENTO \\
\hline COMPVIVC & Compartilha vivências & $\begin{array}{l}\text { (1) Muito insatisfeita (2) (3) } \\
\text { (4) (5) (6) Muito satisfeita } \\
\text { (7) NSA }\end{array}$ \\
\hline AJUDANIC & Ajuda a manter o ânimo & $\begin{array}{l}\text { (1) Muito insatisfeita (2) (3) } \\
\text { (4) (5) (6) Muito satisfeita } \\
(7) \text { NSA }\end{array}$ \\
\hline SITUADIC & Ajuda a sair de situações difíceis & $\begin{array}{l}\text { (1) Muito insatisfeita (2) (3) } \\
\text { (4) (5) (6) Muito satisfeita } \\
(7) \text { NSA }\end{array}$ \\
\hline INTATIDC & Interesse em atividades diárias e problemas & $\begin{array}{l}\text { (1) Muito insatisfeita (2) (3) } \\
\text { (4) (5) (6) Muito satisfeita } \\
(7) \text { NSA }\end{array}$ \\
\hline
\end{tabular}




\begin{tabular}{|c|c|c|}
\hline ROTIESPC & Sai da rotina para fazer coisas especiais & $\begin{array}{l}\text { (1) Muito insatisfeita (2) (3) } \\
\text { (4) (5) (6) Muito satisfeita } \\
\text { (7) NSA }\end{array}$ \\
\hline FALAPESC & Permite falar de coisas pessoais & $\begin{array}{l}\text { (1) Muito insatisfeita (2) (3) } \\
\text { (4) (5) (6) Muito satisfeita } \\
\text { (7) NSA }\end{array}$ \\
\hline DEMQVALC & Demonstra que valoriza o que faço para ele & $\begin{array}{l}\text { (1) Muito insatisfeita (2) (3) } \\
\text { (4) (5) (6) Muito satisfeita } \\
\text { (7) NSA }\end{array}$ \\
\hline TOTALTBC & Tolera altos e baixos & $\begin{array}{l}\text { (1) Muito insatisfeita (2) (3) } \\
\text { (4) (5) (6) Muito satisfeita } \\
\text { (7) NSA }\end{array}$ \\
\hline SERPREOC & Leva a sério as preocupações & $\begin{array}{l}\text { (1) Muito insatisfeita (2) (3) } \\
\text { (4) (5) (6) Muito satisfeita } \\
\text { (7) NSA }\end{array}$ \\
\hline SITUCLFC & Diz coisas que tornam situação clara e fácil & $\begin{array}{l}\text { (1) Muito insatisfeita (2) (3) } \\
\text { (4) (5) (6) Muito satisfeita } \\
\text { (7) NSA }\end{array}$ \\
\hline PERTSPRC & Estará por perto & $\begin{array}{l}\text { (1) Muito insatisfeita (2) (3) } \\
\text { (4) (5) (6) Muito satisfeita } \\
\text { (7) NSA }\end{array}$ \\
\hline
\end{tabular}

Apoio de outras pessoas

\begin{tabular}{|l|l|l|}
\hline \multicolumn{1}{|c|}{ VARIÁVEL } & SIGNIFICADO & PREENCHIMENTO \\
\hline COMPVIVO & Compartilha vivências & $\begin{array}{l}\text { (1) Muito insatisfeita (2) (3) } \\
\text { (4) (5) (6) Muito satisfeita }\end{array}$ \\
\hline AJUDANIO & Ajuda a manter o ânimo & $\begin{array}{l}\text { (1) Muito insatisfeita (2) (3) } \\
\text { (4) (5) (6) Muito satisfeita }\end{array}$ \\
\hline SITUADIO & Ajuda a sair de situações difíceis & $\begin{array}{l}\text { (1) Muito insatisfeita (2) (3) } \\
\text { (4) (5) (6) Muito satisfeita }\end{array}$ \\
\hline INTATIDO & Interesse em atividades diárias e problemas & $\begin{array}{l}\text { (1) Muito insatisfeita (2) (3) } \\
\text { (4) (5) (6) Muito satisfeita }\end{array}$ \\
\hline ROTIESPO & Sai da rotina para fazer coisas especiais & $\begin{array}{l}\text { (1) Muito insatisfeita (2) (3) } \\
\text { (4) (5) (6) Muito satisfeita }\end{array}$ \\
\hline FALAPESO & Permite falar de coisas pessoais & $\begin{array}{l}\text { (1) Muito insatisfeita (2) (3) } \\
(4)(5)(6) \text { Muito satisfeita }\end{array}$ \\
\hline DEMQVALO & Demonstra que valoriza o que faço para ele & $\begin{array}{l}\text { (1) Muito insatisfeita (2) (3) } \\
\text { (4) (5) (6) Muito satisfeita }\end{array}$ \\
\hline TOTALTBO & Tolera altos e baixos & $\begin{array}{l}\text { (1) Muito insatisfeita (2) (3) } \\
\text { (4) (5) (6) Muito satisfeita }\end{array}$ \\
\hline SERPREOO & Leva a sério as preocupações & $\begin{array}{l}\text { (1) Muito insatisfeita (2) (3) } \\
(4)(5)(6) \text { Muito satisfeita }\end{array}$ \\
\hline SITUCLFO & Diz coisas que tornam situação clara e fácil & $\begin{array}{l}\text { (1) Muito insatisfeita (2) (3) } \\
(4)(5)(6) \text { Muito satisfeita }\end{array}$ \\
\hline PERTSPRO & Estará por perto & $\begin{array}{l}\text { (1) Muito insatisfeita (2) (3) } \\
\text { (4) (5) (6) Muito satisfeita }\end{array}$ \\
\hline
\end{tabular}




\section{Avaliação da auto-estima}

\begin{tabular}{|l|l|l|}
\hline VARIÁVEL & SIGNIFICADO & PREENCHIMENTO \\
\hline VALORIGU & Sente que tem valor ou é igual aos outros & $\begin{array}{l}\text { (1) Concordo completamente } \\
\text { (2) Concordo (3) Discordo } \\
\text { (4) Discordo completamente }\end{array}$ \\
\hline NUMQUALI & Sente que tem um grande número de qualidades & $\begin{array}{l}\text { (1) Concordo completamente } \\
\text { (2) Concordo (3) Discordo } \\
\text { (4) Discordo completamente }\end{array}$ \\
\hline SENTFRAC & Sente que é um fracasso & $\begin{array}{l}\text { (1) Concordo completamente } \\
\text { (2) Concordo (3) Discordo } \\
\text { (4) Discordo completamente }\end{array}$ \\
\hline TBEQMAIO & $\begin{array}{l}\text { Sente que é capaz de fazer as coisas tão bem } \\
\text { quanto os outros }\end{array}$ & $\begin{array}{l}\text { (1) Concordo completamente } \\
\text { (2) Concordo (3) Discordo } \\
\text { (4) Discordo completamente }\end{array}$ \\
\hline NAOTEORG & Sente que não tem muito do que se orgulhar & $\begin{array}{l}\text { (1) Concordo completamente } \\
\text { (2) Concordo (3) Discordo } \\
\text { (4) Discordo completamente }\end{array}$ \\
\hline ATITUPOS & Tem uma atitude positiva consigo mesma & $\begin{array}{l}\text { (1) Concordo completamente } \\
\text { (2) Concordo (3) Discordo } \\
\text { (4) Discordo completamente }\end{array}$ \\
\hline SATICONS & Sente-se satisfeita consigo mesma & $\begin{array}{l}\text { (1) Concordo completamente } \\
\text { (2) Concordo (3) Discordo } \\
\text { (4) Discordo completamente }\end{array}$ \\
\hline MARESPCM & Quer ter mais respeito por si mesma & $\begin{array}{l}\text { (1) Concordo completamente } \\
\text { (2) Concordo (3) Discordo } \\
\text { (4) Discordo completamente }\end{array}$ \\
\hline SENTEINU & Sente-se inútil & $\begin{array}{l}\text { (1) Concordo completamente } \\
\text { (2) Concordo (3) Discordo } \\
\text { (4) Discordo completamente }\end{array}$ \\
\hline NAOBOAQC & Não se acha boa que chega & $\begin{array}{l}\text { (1) Concordo completamente } \\
\text { (2) Concordo (3) Discordo } \\
\text { (4) Discordo completamente }\end{array}$ \\
\hline CONTSUVI & Tem controle sobre sua vida & $\begin{array}{l}\text { (1) Concordo completamente } \\
\text { (2) Concordo (3) Discordo } \\
\text { (4) Discordo completamente }\end{array}$ \\
\hline
\end{tabular}




\section{APÊNDICE D}

Termo de Consentimento Livre e Esclarecido

Meu nome é Anne Marie Weissheimer, sou enfermeira e aluna do Programa de PósGraduação (Doutorado), da Escola de Enfermagem de Ribeirão Preto da Universidade de São Paulo, área de concentração: Saúde Pública. Estou desenvolvendo uma pesquisa intitulada: "Correlação do bem-estar psicosocial e da espiritualidade com comportamentos de risco à gestação: tradução, adaptação e validação para uso no Brasil dos instrumentos Prenatal Psychosocial Profile e Spiritual Perspective Scale”, para obtenção do título de Doutora em Enfermagem, sob orientação da Prof ${ }^{\mathrm{a}}$ Dr $^{\mathrm{a}}$ Marli Villela Mamede .

Com esta pesquisa pretendo estudar a relação entre os comportamentos de risco à gestação, o bem-estar psicosocial e a espiritualidade de gestantes. Para isto, gostaria de lhe fazer algumas perguntas, através de dois formulários, bem como coletar algumas informações em seu prontuário. Garanto que estes dados serão usados somente para fins de pesquisa, que você não será identificada em momento algum do estudo e que poderá, a qualquer momento, inclusive enquanto estiver preenchendo os formulários, deixar de participar do mesmo sem prejuízo para si ou ao seu atendimento nesta Unidade de Saúde. Ao término da pesquisa, os dados serão publicados ou apresentados em eventos científicos, entretanto sem revelar a sua identidade ou de qualquer pessoa pesquisada. Não há nenhum custo para você participar da pesquisa.

Esclareço que sua participação é muito importante para que possamos, de modo geral, melhorarmos o cuidado no pré-natal.

Agradeço sua colaboração, coloco-me à disposição para os esclarecimentos que se fizerem necessários, pelo telefone (51) 99775043, inclusive com ligações à cobrar, ou e-mail annemw@eerp.usp.br. Este projeto foi avaliado e aprovado pelo Comitê de Ética em Pesquisa da Prefeitura Municipal de Porto Alegre, cujos telefones são (51) 32892770 e 32892770.

Obrigada,

Anne Marie Weissheimer

Após ter lido e compreendido as informações acima, concordo em participar desta pesquisa e autorizo a utilização dos dados para o presente estudo.

Nome:

Data:

Assinatura: 


\title{
APÊNDICE E \\ Carta ao Comitê de Ética em Pesquisa com fluxo de encaminhamento para profissionais da Área de Saúde Mental
}

Porto Alegre, 03 de outubro de 2006.

\begin{abstract}
À
Dra. Luciane Rampanelli Franco

Coordenadora do Comitê de Ética em Pesquisa

Secretaria Municipal de Saúde

Prefeitura Municipal de Porto Alegre

Nesta Cidade
\end{abstract}

Cara dra. Luciane:

Atendendo à solicitação deste Comitê, encaminho para ser anexado ao projeto de pesquisa que tem o processo de número 001.028266.06.4, as orientações para encaminhamento de gestantes que eventualmente necessitarem de atendimento ou acompanhamento de profissional da área de Saúde Mental.

Conforme exposto, o Plano Municipal de Saúde propõe que o atendimento em Saúde Mental se dê primeiramente na Rede Básica, através de clínico capacitado para tal. Assim, a via para o atendimento em um serviço especializado é a consulta com o clínico geral da área de abrangência de moradia do paciente. O médico clínico geral da Unidade Básica atende os casos de saúde mental e encaminha para as equipes especializadas apenas os casos mais graves.

Foi informado, pela equipe de políticas de saúde da área de Saúde Mental, a qual ambulatório dentro de cada Gerência Distrital os pacientes devem ser encaminhados, bem como qual é o profissional responsável (e seu respectivo telefone), em cada gerência, por estes ambulatórios de saúde mental.

Estando ciente do fluxo de encaminhamento de atendimento na Área de Saúde Mental, no caso de ocorrerem crises emocionais das participantes da pesquisa, esperamos haver atendido à solicitação deste Comitê.

Atenciosamente, 


\section{APÊNDICE F}

Versão final em português do Prenatal Psychosocial Profile

PPP-VP

Número:

\section{PERFIL PSICOSOCIAL NO PRÉ-NATAL (PPP)} auto-estima.

O PPP consiste de três escalas separadas que medem o estresse, o apoio social e a

\section{Avaliação do Estresse}

Vários fatores podem causar estresse e preocupação. Por favor, marque o número correspondente à resposta apropriada, para cada uma das frases abaixo:
(1) nenhum estresse
(2) algum estresse
(3) estresse moderado
(4) estresse intenso

“O quanto (cada frase) causa estresse ou preocupação no momento para você?"

\begin{tabular}{|c|c|c|c|c|c|}
\hline & nenhum & algum & moderado & intenso & \\
\hline $\begin{array}{l}\text { A. Preocupações financeiras (por } \\
\text { exemplo: alimentação, moradia, saúde, } \\
\text { transporte). }\end{array}$ & 1 & 2 & 3 & 4 & PREOCFIN \\
\hline $\begin{array}{l}\text { B. Outras preocupações com dinheiro } \\
\text { (por exemplo: contas, etc). }\end{array}$ & 1 & 2 & 3 & 4 & OUTPREOC \\
\hline $\begin{array}{l}\text { C. Problemas relacionados à família } \\
\text { (companheiro, filhos, etc). }\end{array}$ & 1 & 2 & 3 & 4 & PROBFAMI \\
\hline $\begin{array}{l}\text { D. Ter de mudar de endereço, mesmo } \\
\text { que tenha sido recentemente ou que } \\
\text { acontecerá no futuro. }\end{array}$ & 1 & 2 & 3 & 4 & MUDAREND \\
\hline E. Perda recente de alguém especial. & 1 & 2 & 3 & 4 & PERDRECE \\
\hline F. Gestação atual. & 1 & 2 & 3 & 4 & GESTATUA \\
\hline $\begin{array}{l}\text { G. Estar sofrendo violência/abuso: } \\
\text { sexual, emocional, ou física. }\end{array}$ & 1 & 2 & 3 & 4 & SOFRVIAB \\
\hline H. Problemas com álcool e/ou drogas. & 1 & 2 & 3 & 4 & ALCODROG \\
\hline $\begin{array}{l}\text { I. Problemas no trabalho (por exemplo: } \\
\text { ter sido despedida, etc). }\end{array}$ & 1 & 2 & 3 & 4 & PROBTRAB \\
\hline J. Problemas relacionados aos amigos. & 1 & 2 & 3 & 4 & PROBAMIG \\
\hline K. Sentir-se geralmente sobrecarregada. & 1 & 2 & 3 & 4 & SOBRECAR \\
\hline
\end{tabular}




\section{Avaliação do apoio}

A próxima série de perguntas é sobre o quanto você está satisfeita com o apoio que você recebe de seu companheiro e/ou de outras pessoas. Em primeiro lugar, você tem um companheiro?

1. Não (não responda essa parte, passe para o item Apoio de outras pessoas)

2. Sim

As frases abaixo descrevem vários tipos de apoio. Em uma escala de 1 a 6 , com o número 1 correspondendo a 'muito insatisfeita' e o número 6 correspondendo a 'muito satisfeita', solicito que você marque na tabela o número que corresponde a quanto você se sente satisfeita com o apoio que recebe do seu companheiro.

Apoio do companheiro:

\begin{tabular}{|c|c|c|c|c|c|c|c|}
\hline $\begin{array}{l}\text { A. Compartilha vivências } \\
\text { comigo. }\end{array}$ & 1 & 2 & 3 & 4 & 5 & 6 & COMPVIVC \\
\hline $\begin{array}{l}\text { B. Ajuda a manter meu } \\
\text { ânimo. }\end{array}$ & 1 & 2 & 3 & 4 & 5 & 6 & AJUDANIC \\
\hline $\begin{array}{l}\text { C. Me ajuda a sair de } \\
\text { situações difíceis. }\end{array}$ & 1 & 2 & 3 & 4 & 5 & 6 & SITUADIC \\
\hline $\begin{array}{l}\text { D. Mostra interesse em } \\
\text { minhas atividades diárias e } \\
\text { problemas. }\end{array}$ & 1 & 2 & 3 & 4 & 5 & 6 & INTATIDC \\
\hline $\begin{array}{l}\text { E. Sai de sua rotina para } \\
\text { fazer coisas especiais e } \\
\text { importantes para mim. }\end{array}$ & 1 & 2 & 3 & 4 & 5 & 6 & ROTIESPC \\
\hline $\begin{array}{l}\text { F. Me permite falar de coisas } \\
\text { que são bastante pessoais e } \\
\text { particulares. }\end{array}$ & 1 & 2 & 3 & 4 & 5 & 6 & FALAPESC \\
\hline $\begin{array}{l}\text { G. Demonstra para mim que } \\
\text { valoriza o que eu faço para } \\
\text { ele. }\end{array}$ & 1 & 2 & 3 & 4 & 5 & 6 & DEMQVALC \\
\hline $\begin{array}{l}\text { H. Tolera meus "altos e } \\
\text { baixos" e meus } \\
\text { comportamentos } \\
\text { inesperados. }\end{array}$ & 1 & 2 & 3 & 4 & 5 & 6 & TOLALTBC \\
\hline $\begin{array}{l}\text { I. Me leva a sério quando eu } \\
\text { tenho preocupações. }\end{array}$ & 1 & 2 & 3 & 4 & 5 & 6 & SERPREOC \\
\hline $\begin{array}{l}\text { J. Me diz coisas que tornam } \\
\text { minha situação mais clara e } \\
\text { fácil de ser compreendida. }\end{array}$ & 1 & 2 & 3 & 4 & 5 & 6 & SITUCLFC \\
\hline $\begin{array}{l}\text { K. Deixa claro que ele estará } \\
\text { por perto se eu precisar }\end{array}$ & 1 & 2 & 3 & 4 & 5 & 6 & PERTSPRC \\
\hline
\end{tabular}


Por favor, agora leia as mesmas frases e responda o quanto você se sente satisfeita em relação ao apoio que recebe de outras pessoas:

Apoio de outras pessoas:

\begin{tabular}{|c|c|c|c|c|c|c|c|}
\hline $\begin{array}{l}\text { A. Compartilha vivências } \\
\text { comigo. }\end{array}$ & 1 & 2 & 3 & 4 & 5 & 6 & COMPVIVO \\
\hline $\begin{array}{l}\text { B. Ajuda a manter meu } \\
\text { ânimo. }\end{array}$ & 1 & 2 & 3 & 4 & 5 & 6 & AJUDANIO \\
\hline $\begin{array}{l}\text { C. Me ajuda a sair de } \\
\text { situações difíceis. }\end{array}$ & 1 & 2 & 3 & 4 & 5 & 6 & SITUADIO \\
\hline $\begin{array}{l}\text { D. Mostra interesse em } \\
\text { minhas atividades diárias e } \\
\text { problemas. }\end{array}$ & 1 & 2 & 3 & 4 & 5 & 6 & INTATIDO \\
\hline $\begin{array}{l}\text { E. Sai de sua rotina para } \\
\text { fazer coisas especiais e } \\
\text { importantes para mim. }\end{array}$ & 1 & 2 & 3 & 4 & 5 & 6 & ROTIESPO \\
\hline $\begin{array}{l}\text { F. Me permite falar de coisas } \\
\text { que são bastante pessoais e } \\
\text { particulares. }\end{array}$ & 1 & 2 & 3 & 4 & 5 & 6 & FALAPESO \\
\hline $\begin{array}{l}\text { G. Demonstra para mim que } \\
\text { valoriza o que eu faço para } \\
\text { ele/ela. }\end{array}$ & 1 & 2 & 3 & 4 & 5 & 6 & DEMQVALO \\
\hline $\begin{array}{l}\text { H. Tolera meus "altos e } \\
\text { baixos" e meus } \\
\text { comportamentos } \\
\text { inesperados. }\end{array}$ & 1 & 2 & 3 & 4 & 5 & 6 & TOLALTBO \\
\hline $\begin{array}{l}\text { I. Me leva a sério quando eu } \\
\text { tenho preocupações. }\end{array}$ & 1 & 2 & 3 & 4 & 5 & 6 & SERPREOO \\
\hline $\begin{array}{l}\text { J. Me diz coisas que tornam } \\
\text { minha situação mais clara e } \\
\text { fácil de ser compreendida. }\end{array}$ & 1 & 2 & 3 & 4 & 5 & 6 & SITUCLFO \\
\hline $\begin{array}{l}\text { K. Deixa claro que ele/ela } \\
\text { estará por perto se eu } \\
\text { precisar }\end{array}$ & 1 & 2 & 3 & 4 & 5 & 6 & PERTSPRO \\
\hline
\end{tabular}




\section{Avaliação da auto-estima}

Todos nós carregamos conosco algum tipo de imagem de nós mesmos. As frases abaixo são frases que geralmente as pessoas usam para se descreverem. Por favor, leia cada uma e marque abaixo o número que indica o quanto você concorda ou não se a frase descreve você, conforme os números abaixo:
(1) Concordo completamente
(2) Concordo
(3) Discordo
(4) Discordo completamente

\begin{tabular}{|c|c|c|c|c|c|}
\hline & $\begin{array}{c}\text { Concordo } \\
\text { completa- } \\
\text { mente }\end{array}$ & Concordo & Discordo & $\begin{array}{l}\text { Discordo } \\
\text { comple- } \\
\text { tamente }\end{array}$ & \\
\hline $\begin{array}{l}\text { A. Você sente que é uma } \\
\text { pessoa de valor, ou pelo } \\
\text { menos que é igual aos outros. }\end{array}$ & 1 & 2 & 3 & 4 & VALORIGU \\
\hline $\begin{array}{l}\text { B. Você sente que tem um } \\
\text { grande número de qualidades. }\end{array}$ & 1 & 2 & 3 & 4 & NUMQUALI \\
\hline $\begin{array}{l}\text { C. No final das contas, você } \\
\text { sente que é um fracasso. }\end{array}$ & 1 & 2 & 3 & 4 & SENTFRAC \\
\hline $\begin{array}{l}\text { D. Você se sente capaz de } \\
\text { fazer as coisas pelo menos tão } \\
\text { bem quanto a maioria das } \\
\text { pessoas. }\end{array}$ & 1 & 2 & 3 & 4 & TBEQMAIO \\
\hline $\begin{array}{l}\text { E. Você sente que não tem } \\
\text { muito do que se orgulhar. }\end{array}$ & 1 & 2 & 3 & 4 & NAOTEORG \\
\hline $\begin{array}{l}\text { F. Você tem uma atitude } \\
\text { positiva consigo mesma. }\end{array}$ & 1 & 2 & 3 & 4 & ATITUPOS \\
\hline $\begin{array}{l}\text { G. De modo geral, você se } \\
\text { sente satisfeita consigo } \\
\text { mesma. }\end{array}$ & 1 & 2 & 3 & 4 & SATICONS \\
\hline $\begin{array}{l}\text { H. Você queria ter mais } \\
\text { respeito por si mesma. }\end{array}$ & 1 & 2 & 3 & 4 & MARESPCM \\
\hline $\begin{array}{l}\text { I. Às vezes, você se sente } \\
\text { inútil. }\end{array}$ & 1 & 2 & 3 & 4 & SENTEINU \\
\hline $\begin{array}{l}\text { J. Às vezes, você acha que } \\
\text { não é boa que chega. }\end{array}$ & 1 & 2 & 3 & 4 & NAOBOAQC \\
\hline $\begin{array}{l}\text { K. Você acha que controla a } \\
\text { sua vida. }\end{array}$ & 1 & 2 & 3 & 4 & CONTSUVI \\
\hline
\end{tabular}




\section{APÊNDICE G}

Número:

Avaliação do PPP

Questionar a participante/gestante se compreendeu todos os itens do instrumento, se algum teve significado ambíguo, anotando qual o item e qual a dúvida que a participante teve. Questionar também se as respostas são claras e fáceis de serem escolhidas.

Coletador: Data: 
ANEXOS 


\section{ANEXO A \\ The Prenatal Psychosocial Profile (PPP)}

\section{The Prenatal Psychosocial Profile (PPP)}

The PPP consists of three separate scales to measure stress, social support, and self-esteem.

\section{Assessment of Stress}

Ask women to what extent the following factors are current stressors/hassles. Circle the number corresponding to the appropriate response: (1) No stress, (2) Some stress, (3) Moderate stress, or (4) Severe stress. Higher scores indicate increased stress.

We ask: "To what extent are (read choice) a current stressor/hassle for you?"
A. Financial worries (e.g., food, shelter, health care, $\begin{array}{lllll}1 & 2 & 3 & 4\end{array}$ transportation)
B. Other money worries (e.g., bills, etc).
C. Problems related to family (partner, children, etc) $1 \begin{array}{llll}1 & 2 & 3 & 4\end{array}$
D. Having to move, either recently or in the future $\begin{array}{lllll}1 & 2 & 3 & 4\end{array}$
E. Recent loss of a loved one $\quad \begin{array}{lllll}1 & 2 & 3 & 4\end{array}$
$\begin{array}{lllll}\text { F. Current pregnancy } & 1 & 2 & 3 & 4\end{array}$
G. Current abuse: sexual, emotional, or physical $\quad \begin{array}{lllll}1 & 2 & 3 & 4\end{array}$

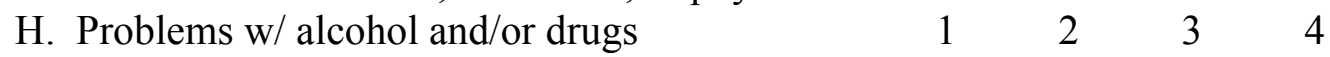
I. Work problems (e.g., being laid off, etc.) $\quad \begin{array}{lllll}1 & 2 & 3 & 4\end{array}$
$\begin{array}{lllll}\text { J. Problems relate to friends } & 1 & 2 & 3 & 4\end{array}$
K. Feeling generally "overloaded" $\quad 1 \quad r \begin{array}{llll} & 2 & 3 & 4\end{array}$

\section{Assessment of Support}

If women have a partner, then this series of questions is first asked as they pertain to the partner. Women rate their partner on a scale of 1 to 6 , with 1 being very dissatisfied and 6 being very satisfied. Then, they are asked the same series of questions again, but are asked to respond based on how satisfied they feel about the support they receive from other people. If women do not have a partner, the first series is omitted and the questions are only asked once. Higher scores indicate increased satisfaction with support.

We ask: "The next set of questions asks how satisfied you are with the amount of support you receive from your partner and/or other people. First of all, do you have a partner?"

1. No (ask only about support from others)

2. Yes 
"I will read you a list of statements describing types of support. On a scale of 1 to 6 , with 1 being very dissatisfied and 6 being very satisfied, I want you to tell me how satisfied you are with the support you receive from (your partner/other people)."

A. Shares similar experiences with me

B. Helps keep up my morale

C. Helps me out when I'm in a pinch

D. Shows interest in my daily activities and problems

E. Goes out of his/her way to do special or thoughtful things for me

F. Allows me to talk about things that are very personal and private

G. Lets me know I am appreciated for the things I do for him/her

H. Tolerates my ups and downs and unusual $\quad \begin{array}{llllllll}1 & 2 & 3 & 4 & 5 & 6\end{array}$ behaviors

I. Takes me seriously when I have concerns

J. Says things that make my situation clearer and easier to understand

$\mathrm{K}$. Lets me know that he/she will be around if I need assistance

$\begin{array}{llllll}1 & 2 & 3 & 4 & 5 & 6 \\ 1 & 2 & 3 & 4 & 5 & 6 \\ 1 & 2 & 3 & 4 & 5 & 6 \\ 1 & 2 & 3 & 4 & 5 & 6 \\ 1 & 2 & 3 & 4 & 5 & 6 \\ 1 & 2 & 3 & 4 & 5 & 6 \\ 1 & 2 & 3 & 4 & 5 & 6 \\ 1 & 2 & 3 & 4 & 5 & 6 \\ 1 & 2 & 3 & 4 & 5 & 6 \\ 1 & 2 & 3 & 4 & 5 & 6 \\ 1 & 2 & 3 & 4 & 5 & 6\end{array}$

\section{Assessment of Self-Esteem}

Read the following statements to participants and ask them to respond to the questions as follows: (1) Strongly agree, (2) Agree, (3) Disagree, or (4) Strongly disagree. A laminated card with these choices can be helpful, as questions with a * are negatively worded and can throw participants off.

We say: "We all have some kind of picture of ourselves we carry with us. I'm going to read you a list of statements that people have used to describe themselves. I would like you to tell me how much you agree or disagree that this statement describes you. You can refer to the card with the smiling faces if that helps."
A. Feel that you're a person of worth, at least on an equal basis with others.
B. Feel that you have a number of good qualities.
C. All in all, feel that you are a failure.*
D. Feel you are able to do things as well as most other people.
E. Feel you do not have much to be proud of. *
F. Take a positive attitude toward yourself.

$\begin{array}{llll}1 & 2 & 3 & 4 \\ 1 & 2 & 3 & 4 \\ 1 & 2 & 3 & 4 \\ 1 & 2 & 3 & 4 \\ 1 & 2 & 3 & 4 \\ & 1 & 2 & 3\end{array}$
G. On the whole, feel satisfied with yourself.
H. Wish you could have more respect for yourself. *
I. Feel useless at times.*
J. At times think you are no good at all.*
$\mathrm{K}$. Feel like you have control over your life.

$\begin{array}{llll}1 & 2 & 3 & 4 \\ 1 & 2 & 3 & 4 \\ 1 & 2 & 3 & 4 \\ 1 & 2 & 3 & 4 \\ 1 & 2 & 3 & 4\end{array}$


ANEXO B

\section{E-mails Autorização Professora Mary Ann Curry}

\section{Anne Marie}

De: "Mary Curry" <currym@ohsu.edu>

Para: <anne_marie@uol.com.br>

Enviada em: terça-feira, 2 de agosto de 2005 12:18

Anexar: $\quad$ ThePrenatalPsychosocialProfile.doc; pppletter.doc

Assunto: $\quad$ Re: prenatal psychosocial profile

Hello Anne,

Thank you for your interest in the Prenatal Psychosocial Profile. I am not aware of any Portuguese translation or use in Brazil. I am attaching a copy of the instrument and a letter that describes how to score it. Best wishes.

Mary Ann Curry

>> "Anne Marie" <anne marie@uol.com.br>07/17/05 6:58 PM >>

Dear Professor Curry:

Hello!

My name is Anne Marie Weissheimer, I am a doctoral student at the University of São Paulo, School of Nursing of Ribeirão Preto, São Paulo, Brazil, (www.eerp.usp.br), under the orientation of Professor Marli Villela Mamede.

As I am developing my doctoral dissertation project to do a research on spirituality and social wellbeing and their relationships with pregnancy outcomes, I got in touch with your work, specially CURRY; CAMPBELL; CHRISTIAN. Validity and reliability testing of the prenatal psychosocial profile. Research in Nursing \& Health, 17, 127-135, 1994; and CURRY; BURTON; FIELDS. The prenatal psychosocial profile: a research and clinical tool. Research in Nursing \& Health, 21, 211219, 1998.

I am writing this e-mail to show my interest in working with the scale you have developed: the Prenatal Psychosocial Profile.

So, that I would like to ask you:

- Have the profile been translated to portuguese?

- Have the scale been adapted to Brazilian population?

- Would you kindly consent on the translation, validation and use of your scale in Brazil?

Thank you for your attention, and looking forward to an answer, my best regards, Anne Marie

avast! Antivirus: Outbound message clean.

Virus Database (VPS): 0528-6, 16/07/2005

Tested on: 17/7/2005 22:58:21

avast! - copyright (c) 1988-2004 ALWIL Software.

http://www.avast.com 


\section{Anne Marie}

De: $\quad$ "Mary Curry" < currym@ohsu.edu>

Para:_<anne_marie@uol.com.br>

Enviada em: quarta-feira, 3 de agosto de 2005 14:29

Assunto: Re: PPP

Dear Anne Marie,

You have my permission to go ahead; I don't have any forms to complete. I would be very happy to review the back translated version. I hope it is helpful to you in your study. Good luck!

Mary Ann Curry

>> "Anne Marie" <anne marie@uol.com.br>08/02/05 4:05 PM >>

Professor Curry!

Thank you so much for your reply!

I'll look over the material you have sent me right away, and will start working on the translation and adaptation process soon.

I would like to ask you if I can count on your expertise on this process, since I'll need your approval of the Portuguese version, once it is back translated to English.

Would you like me to send you a request form, or anything like that?

Also, I would like to re-affirm you that as soon as I have any results, I will a copy send to you, with an abstract of the dissertation.

Thank you, once again, for your kind attention!

Anne Marie

avast! Antivirus: Outbound message clean.

Virus Database (VPS): 0531-1, 02/08/2005

Tested on: 2/8/2005 20:05:55

avast! - copyright (c) 1988-2004 ALWIL Software.

http://www.avast.com

avast! Antivirus: Inbound message clean.

Virus Database (VPS): 0531-2, 03/08/2005 


\section{ANEXO C \\ Aprovação Comitê de Ética em Pesquisa da Secretaria Municipal de Saúde de Porto Alegre}

\section{$\frac{1}{\frac{1}{3}}$ \\ Prefeitura Municipal de Porto Alegre Secretaria Municipal de Saúde Comitê de Ética em Pesquisa}

Pesquisador (a) Responsável: Anne Marie Weissheimer

Registro do CEP:54 Processo $\mathrm{N}^{\circ}$.001.028266.06.4

Instituição onde será desenvolvido: Secretaria Municipal de Saúde de Porto Alegre Situação: APROVADO

O Comitê de Ética em Pesquisa da Secretaria Municipal de Saúde de Porto Alegre analisou na sessão do dia 05/10/2006 o processo $\mathrm{N}^{\circ} .001 .028266 .06 .4$, referente ao projeto de pesquisa: "Correlação do bem-estar psicosocial e da espiritualidade com comportamentos de risco à gestação: tradução adaptação e validação para uso no Brasil dos instrumentos "Prenatal psychosocial Profile" e "Spiritual Perspective scale"., tendo como pesquisador responsável, Anne Marie Weissheimer, cujo objetivo é "estudar a correlação entre o bem-estar psicosocial e a espiritualidade com comportamentos de risco à gestação".

Assim, em conformidade com os requisitos éticos, classificamos o presente protocolo como APROVADO.

Porto Alegre, 05/10/2006

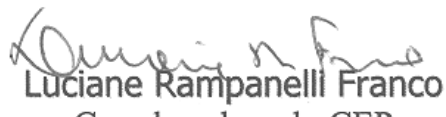

Coordenadora do CEP 


\author{
ANEXO D \\ Back-translation (consenso tradutores)
}

Number:

\title{
PSYCHO-SOCIAL PROFILE IN PRENATAL (PPP)
}

The PPP consists of three separate scales to measure stress, social support and self-esteem.

\section{Stress Evaluation}

Ask women in what amount the following factors are cause of stress/annoyance in this moment. Circle the number that matches the suitable answer: (1) No stress, (2) Some stress, (3) Moderate stress, or (4) Intense stress. Higher scores indicate increasing stress.

Question: "In what amount (read the option) is a cause of stress or annoyance for you in this moment?

$\begin{array}{lllll}\begin{array}{l}\text { A. Financial concerns (ex: food, housing, health, } \\ \text { transportation) }\end{array} & 1 & 2 & 3 & 4 \\ \begin{array}{l}\text { B. Other concerns about money (ex: bills, etc) } \\ \text { C. Family related problems (partner, children, etc) }\end{array} & 1 & 2 & 3 & 4 \\ \begin{array}{l}\text { D. You had to move - recently happened or will } \\ \text { happen in the near future }\end{array} & 1 & 2 & 3 & 4 \\ \begin{array}{l}\text { E. Recent passing away of someone special } \\ \text { F. Present pregnancy }\end{array} & 1 & 2 & 3 & 4 \\ \begin{array}{l}\text { G. To be suffering abuse/violence: sexual, } \\ \text { emotional, or physical }\end{array} & 1 & 2 & 3 & 4 \\ \begin{array}{l}\text { H. Problems with alcohol and/or drugs } \\ \text { I. Problems at work (ex: having been fired, etc) }\end{array} & 1 & 2 & 3 & 4 \\ \text { J. Problems related to friends } & 1 & 2 & 3 & 4 \\ \text { K. Frequently feeling overburdened } & 1 & 2 & 3 & 4 \\ \end{array}$

\section{Support evaluation}

If women have a partner, this set of questions is initially about the partner. Women evaluate their partners in a scale that goes from 1 to 6 , where 1 means "very unsatisfied" and 6 means "very satisfied". After that, they receive the same set of questions, but they are asked to answer based in how much they feel satisfied about support they have been receiving from other people. If they do not have a partner, the first set of questions is skipped and the questions are asked just once. Higher scores indicate more satisfaction with the support they've been receiving.

We ask: "The next set of questions is about how much you are satisfied with the support you have been receiving from your partner and/or other people. In first place, do you have a partner?"

\section{No (asked only about support from others)}

2. Yes

"I'll read for you a list of statements that describe types of support. On a scale that goes from 1 to 6 , where 1 means 'very unsatisfied' and 6 means 'very satisfied', I will ask you to tell me 
how much do you feel satisfied with the support you've been receiving from (your partner/other people)."

A. Shares experiences with me.

B. Helps to cheer me up.

C. Helps me to get out of difficult situations.

D. Shows interest in my daily activities and problems.

E. Leaves his/her routine to do special and
important things for me.

F. Allows me to talk about personal and private things.

G. Shows me that gives value to the thing I do for him/her.

H. Tolerates my ups and downs and my unusual behavior.

I. Takes me seriously when I have preoccupations.

J. Tells me things that make my situation clearer and easier to be understood.

$\mathrm{K}$. Makes it clear he/she will be at hand if I need it.

$\begin{array}{llllll}1 & 2 & 3 & 4 & 5 & 6 \\ 1 & 2 & 3 & 4 & 5 & 6 \\ 1 & 2 & 3 & 4 & 5 & 6 \\ 1 & 2 & 3 & 4 & 5 & 6 \\ 1 & 2 & 3 & 4 & 5 & 6 \\ 1 & 2 & 3 & 4 & 5 & 6 \\ 1 & 2 & 3 & 4 & 5 & 6 \\ 1 & 2 & 3 & 4 & 5 & 6 \\ 1 & 2 & 3 & 4 & 5 & 6 \\ 1 & 2 & 3 & 4 & 5 & 6 \\ 1 & 2 & 3 & 4 & 5 & 6\end{array}$

\section{Self-esteem evaluation}

Read the following sentences to the participants and ask them to answer the questions as following: (1) I agree totally, (2) I agree, (3) I don't agree, and (4) I totally disagree. A card with the options above might be useful, since the questions with a $*$ are written in the negative form and might confuse the participants.

We say: "We all carry with us some kind of image about ourselves. I'll read a list of sentences to you, that people use to describe themselves. I would like you to tell me in what amount do you agree or not, that each statement describes yourself. [You can show the smiling or sad face of the card, if it helps you.]"

A. You feel that you are a person of value, at least that you are equal to the others.

B. You feel that you have a great number of qualities.

C. At the end, you feel you are a failure.*

D. You feel you can do things at least as well as most other people.

E. You feel there's not much to be proud of.*

F. You have a positive attitude about yourself.

G. In general you feel satisfied about yourself.

H. You would like to have more self-respect. *

I. Sometimes you feel useless. *

J. Sometimes you feel you're not good enough.*

K. You feel like having control of your life.

$\begin{array}{llll}1 & 2 & 3 & 4 \\ 1 & 2 & 3 & 4 \\ 1 & 2 & 3 & 4 \\ 1 & 2 & 3 & 4 \\ & & & \\ 1 & 2 & 3 & 4 \\ 1 & 2 & 3 & 4 \\ 1 & 2 & 3 & 4 \\ 1 & 2 & 3 & 4 \\ 1 & 2 & 3 & 4 \\ 1 & 2 & 3 & 4 \\ & & & \\ 1 & 2 & 3 & 4\end{array}$




\section{ANEXO E \\ E-mail professora Mary Ann Curry com aprovação da back translation}

\section{Anne Marie}

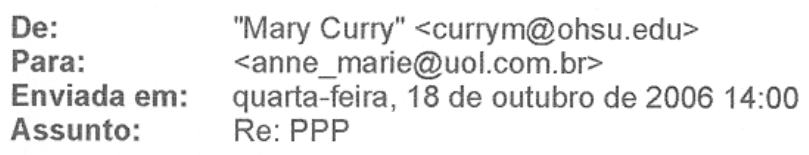

Dear Anne Marie,

I feel terrible about you not hearing from me. However, the emails you sent about visiting me in the US never arrived. I don't know if there was a problem with me getting my work emails from my home office computer or what. I feel very badly about not responding to you. However, I could not have offered you a very satisfactory experience as I have retired and am not at the University any longer. The best description of how I developed the PPP is in the 1994 paper: Validity and reliability testing of the Psychosocial Assessment Tool", Research in Nursing \& Health, 17, 127-135. and the 1998 paper in the same journal 21, 211-219.

You have NOT been a bother, and I hope the remainder of your studies goes much easier. I have read your back translation of the instrument and do not see any problems with it. The important thing is that the meaning of the items make sense to your participants.

All my best wishes for your study and completing your dissertation. I am so sorry for not being in contact sooner. If I can be of any help, please let me know.

Mary Ann Curry

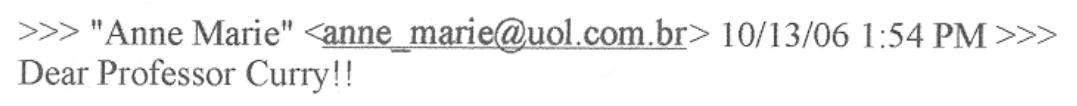

Once again, here am I to bother you!

I am realy concerned that I haven't heard from you in a very long while, but perhaps that's happening just because I am always bothering you!!! :)

Well, I won't be able anymore to go over and stay for a period of time at any University abroad. My doctoral period is almost over, and I must hurry and finish my dissertation as soon as possible.

I am sending, attached with this e-mail, a version of the PPP, as it came out after the backtranslation from Portuguese to English.

I would appreciate very much if you could make any comments on it.

Expecting to hear from you soon, thank you so much

Anne Marie 